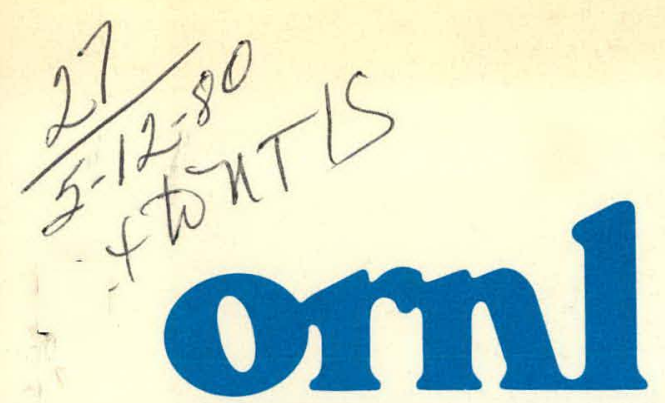

OAK RIDGE NATIONAL LABORATORY

UNION CARBIDE

\title{
IDENTIFICATION OF TECHNICAL PROBLEMS ENCOUNTERED IN THE SHALLOW LAND BURIAL OF LOW-LEVEL RADIOACTIVE WASTES
}

\author{
D. G. Jacobs \\ J. S. Epler \\ R. R. Rose
}

EVALUATION RESEARCH CORPORATION

25 East Tennessee Avenue

Oak Ridge, Tennessee 37830

Under Contract No. 11V-13619V

OPERATED BY

UNION CARBIDE CORPORATION FOR THE UNITED STATES DEPARTMENT OF ENERGY 


\section{DISCLAIMER}

This report was prepared as an account of work sponsored by an agency of the United States Government. Neither the United States Government nor any agency Thereof, nor any of their employees, makes any warranty, express or implied, or assumes any legal liability or responsibility for the accuracy, completeness, or usefulness of any information, apparatus, product, or process disclosed, or represents that its use would not infringe privately owned rights. Reference herein to any specific commercial product, process, or service by trade name, trademark, manufacturer, or otherwise does not necessarily constitute or imply its endorsement, recommendation, or favoring by the United States Government or any agency thereof. The views and opinions of authors expressed herein do not necessarily state or reflect those of the United States Government or any agency thereof. 


\section{DISCLAIMER}

Portions of this document may be illegible in electronic image products. Images are produced from the best available original document. 
Printed in the United States of Amerıca. Available from National Technical Information Service

U.S. Department of Commerce

5285 Port Royal Road, Springfield, Virginia 22161

NTIS price codes-Printed Copy: A09; Microfiche A01

This report was prepared as an account of work sponsored by an agency of the United States Government. Neither the United States Government nor any agency thereof, nor any of their employees, makes any warranty, express or implied, or assumes any legal liability or responsibility for the accuracy, completeness, or usefulness of any information, apparatus, product, or process disclosed, or represents that its use would not infringe privately owned rights. Reference herein to any specific commercial product, process, or service by trade name, trademark, manufacturer, or otherwise, does not necessarily constitute or imply its endorsement, recommendation, or favoring by the United States Government or any agency therenf The views and opinions of authors expressed herein do not necessarily state or reflect those of the United States Government or any agency thereof. 


\author{
IDENTIFICATION OF TECHNICAL PROBLEMS \\ ENCOUNTERED IN THE SHALLOW LAND BURIAL \\ OF LOW-LEVEL RADIOACTIVE WASTES
}

by

D. G. Jacobs, J. S. Epler, and R. R. Rose

EVALUATION RESEARCH CORPORATION

25 East Tennessee Avenue

Oak Ridge, Tennessee 37830

Under Contract No. 11V-13619V

March 1980

NOTICE. This document contains information of a preliminary nature. It is subject to revision or correction and therefore does not represent a final report.

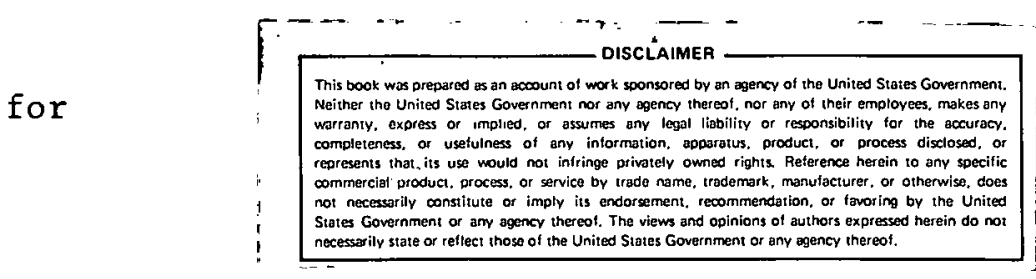

OAK RIDGE NATIONAL LABORATORY

nak. Ridge, Tennessee 37830

operated by

UNION CARBIDE CORPORATION

for the

DEPARTMENT OF ENERGY

Contract W-7405-Eng-26 
THIS PAGE

\section{WAS INTENTIONALLY LEFT BLANK}


TABLE OF CONTENTS

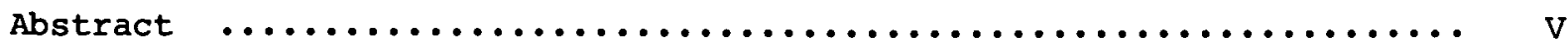

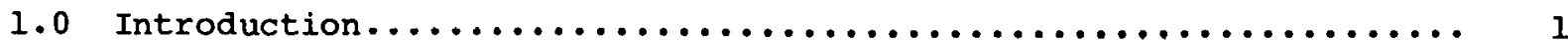

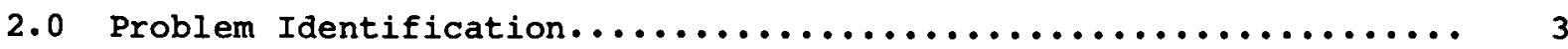

2.1 site..........................................

2.1 .1 water Management........................... 3

2.1.2 Proximity of Trenches to Groundwater and Surface water............................. 6

2.1.3 Biological Intrusion and Translocation............ 6

2.1.4. Proximity of Trenches to site Boundaries.......... 7

2.2 waste......................................

2.2.1 Waste Identification and Quantification........... 7

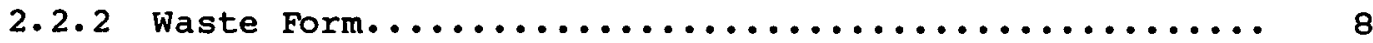

2.2.3 Waste Migration............................ 8

2.3 Operation...................................... 10

2.3.1 Trench structure Management.................... 10

2.3.2 Waste Receipts............................. 11

2.3.3 Security Control........................... 12

2.3.4 Safety control (Fires)........................ 12

2.3.5 Space Utilization.......................... 13

2.3.6 Post-Operations Criteria .................... 13

2.3.7 Waste Package Design......................... 13

2.4 Performance Evaluation.............................. 14

2.4.1 Monitoring of Releases......................... 14

2.4.2 Evaluation of Burial Ground Performance............ 14

2.4.3 Prediction of Future Performance................. 15

2.4 .4 Need for Hydrologic Data...................... 16

3.0 Technical Issues....................................18

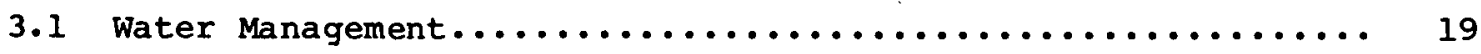

3.1.1 Management to Reduce Trench Infiltration........... 19

3.1.2 Management to Reduce Trench Cap Erosion............ 21

3.1.3 Management Balance in Infiltration and Erosion

Controls................................ 22

3.2 Radionuclide Migration.............................. 23

3.2.1 Groundwater Movement and Dispersion................ 24 
3.2.2 Mechanisms of Radionuclide Interaction in the

Ground................................

3.2.2.1 Effects of chemical conditions on the : chemical and physical properties of specific radionuclides................. 26

3.2.2.2 Effects of physical conditions on radionuclide transport................. 29

3.2.3 Site Specific Measurements Related to Radionuclide Migration................................

3.2.3.1 Laboratory measurements related to

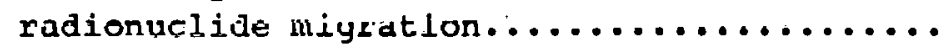

3.2.3.2 Field measurements of radionualide

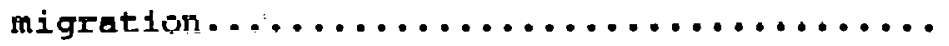

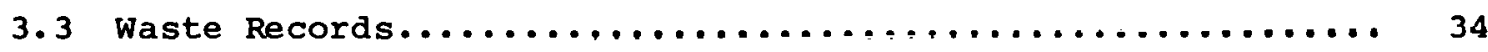

3.3.1 Waste Characterization at the waste source......... 34

3.3.2 Waste Characterization at the Receiving site....... 35

3.3.3 Waste Characterization in the Field.............. 36

3.4 Performance Monitoring and Evaluation................ 37

3.4.1 Conceptual Design of Monitoring systems........... 38

3.4.2 Development of Performance Standards ............. 39

3.4.3 Development of Technology for Monitoring.......... 41

3.5 Predictive Capabilities............................ 4.

3.5.1 Development of a Comprehensive Mulel Lo Depict All Significant Pathways of Radionuclide Transport from Burial Ground Operations...................

3.5.2 Development of Models for Transport by Specific

Environmental Pathways......................

3.6 space Utilization.............................

3.6.1 Evaluation of Vol ime Rerurtion Tochniques.......... 47

3.6.2 Evaluation of Modifications in Space Utilization.....

3. 5 Management Practices.............................

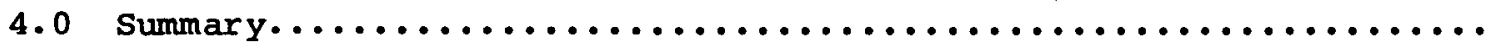

APPENDIX........................................

REFERENCES....................................... 165 


\author{
IDENTIFICATION OF TECHNICAL PROBLEMS \\ ENCOUNTERED IN THE SHALLOW LAND BURIAL \\ OF LOW-LEVEL RADIOACTIVE WASTES
}

\author{
D.G. Jacobs \\ J.S. Epler \\ R. R. Rose
}

Evaluation Research corporation

ABSTRACT

A review of problems encountered in the shallow land burial of low-level radioactive wastes has been made in support of the technical aspects of the National Low-Level Waste (LLW) Management Research and Development Program being administered by the Low-Level Waste Managetment Program office, Oak Ridge National Iaboratory. The operating histories of burial sites at six major DOE and five commercial facilities in the U.S. have been examined and several major problems identified. The problems experienced at the sites have been grouped into general categories dealing with site development, waste characterization, operation, and performance evaluation. Based on this grouping of the problems, a number of major technical issues have been identified which should be incorporated into program plans for further research and development. For each technical issue a discussion is presented relating the issue to a particular problem, 
identifying some recent or current related research, and suggesting further work necessary for resolving the issue.

Major technical issues which have been identified include the need for improved water management, further understanding of the effect of chemical and physical parameters on radionuclide migration, more comprehensive waste records, improved programs for performance monitoring and evaluation, development of better predictive capabilities, evaluation of space utilization, and improved management control. 
1

\author{
IDENTIFICATION OF TECHNICAL PROBLEMS \\ ENCOUNTERED IN THE SHALLOW LAND BURIAL \\ OF LOW-LEVEL RADIOACTIVE WASTES
}

D.G. Jacobs

J.S. Epler

R. R. Rose

Evaluation Research Corporation

\title{
1.0 INTRODUCTION
}

Land burial of solid, low-level radioactive waste has been practiced at facilities operated under contract to the Department of Energy since the beginning of operations in the early 1940's during the Manhattan Project. The primary consideration in location of these early waste burial grounds was their accessibility to the source of waste production. After it became apparent that the facilities would be operated indefinitely, more concern was given to the long-term environmental consequences.

The goal of radioactive waste management is to restrict releases of radioactivity into the uncontrolled environment to levels which do not pose a threat to public health or impair environmental quality. Complete isolation by land burial is difficult, if not impossible, but no consensus has been reached on performance standards expressing acceptable levels of release. Thus, efforts are taken to minimze releases whenever practical. The purpose of this review is to identify problems that have been encountered in land-burial operations and to suggest technical efforts that 
should be explored in research, development, and demonstration programs. This has been accomplished by reviewing recent literature on the site characteristics and problems encountered in the operation of the burial grounds at six major facilities operated under contract for the Department of Energy and at five commercial facilities. Summaries of these reviews are presented in the Appendix.

Problems encountered at the specific sites are grouped into general categories in section 2.0. This facilitates the formulation of technical issues needing further research and development. These technical issues are then discussed in section 3.0 . 


\subsection{PROBLEM IDENTIFICATION}

Problems encountered at six major land burial facilities operated under contract for the Department of Energy and at five commercial facilities are identified in Appendix on the basis of a review of recent literature pertaining to the specific sites. The literature reviewed consisted of those papers and reports obtained through the Ecological Sciences Information Center of the Oak Ridge National Laboratory; copies of the references are maintained at the center. It is likely that more thorough reviews and discussions with operators of shallow land burial facilities would provide a more accurate analysis and a more thorough listing of the technical problems encountered, but the problems identified in this report are those considered by previous workers to be worthy of reporting in the literature.

The problems have been classified into major categories--(1) Site; (2) Waste; (3) Operation; and (4) Performance Evaluation--following the classification of the Shallow Land Burial steering Committee. The classification of problems has been further broken down into specific techrical areas within each category.

\subsection{Site}

\section{$\underline{2.1 .1 \text { Water Management }}$}

The most serious technical problems in shaliow land burial are related to water management. Water provides a primary vehicle both for erosional processes, which can reduce the structural integrity of the waste trenches and the trench caps, and for migration of radionuclides. Radionuclide 
migration in water, and subsequent possible exposure to the public, begins with the entry of water into the burial trench. The most common ways water comes into contact with the waste are from infiltration of precipitation through the trench caps and/or walls or from erosion leading to exposure of the buried waste.

Water has come into contact with waste in burial trenches at the Oak Ridge National Laboratory (NAS76, Du75, DM78, USERDA76a, USERDA76b, Du79, CG076, We79), Maxey Flats (ME76, USERDA76a, Mo77, Har79, USNRC76), West Valley, (Da76, CGO76, USNRC76, USNRC77, Ke179, Har79, Pru79, Mat79, DM76), the Savannah River Plant (Ho76, USERDA76a, USERDA76c, NAS76), the Idaho National Engineering Laboratory (Ba76, Ba79), and Los Alamos Scientific Laboratory (USGS75), i.e. at six of the eleven major land burial facilities. West Valley and Maxey flats have been closed temporarily because of water management problems. Contact between water and wastes at the six burial sites appears to have resulted largely from infiltration of precipitation through the trench backfill.

Uak kidge National Laboratory (ORNL), Maxey Flats, and West Valley burial grounds are located in humid regions and in formations with low permeability. When trenches are constructed, the backfill has a much greater permeability than the undisturbed portions of the formation. This results in an increased rate of infiltration of precipitation into the trench without a corresponding increase in the rate of movement away from the trench. Consequently, the water levels in the trenches may rise and come into contact with the waste. The trenches may continue to accumulate water until the trench overflows at its low point or until the water level rises to a zone of high permeability, such as the interface between the backfill and the original ground surface. This effect is known as the 
"bathtub effect" and is most pronounced in formations of low native permeability. It has occurred to a lesser extent at the Savannah River Plant (SRP), where perched water has built up in the bottoms of some trenches, and at the Idaho National Engineering Laboratory (INEL).

At ORNL the infiltration problem is further aggravated by the fact that in some solid waste disposal areas the incident precipitation is augmented by surface runoff and groundwater flow from areas of higher elevation. Construction activities adjacent to the burial grounds have also altered the hydraulic flow patterns. In addition, some early trenches were oriented with the long axis parallel to the fall line and with the bottom of the trench cut below the natural water table at the downslope end. This trench orientation, plus excessive depths of permeable backfill, increased the infiltration of precipitation and resulted in the elevation of the water table into the burial trenches.

At INEL the burial grounds are located in a natural topographic depression below the level of the channel of the Big Lost River. The burial ground area has been flooded in periods when rapid snownelt combined with high rates of precipitation (USERDA77, Ba76, Ba79). Dikes and drainage ditches have been improved to reduce the problem (Ba79).

For some sites the waste material and backfill have compacted and sagged nonuniformly after waste has been emplaced in trenches, creating breaches in the cover and zones where water can accumulate at the surface. The result has been increased infiltration of water through the trench cover. Subsidence of trench caps and infiltration of water has occurred at ORNL, Maxey Flats, West Valley, INEL, and LASL. At Maxey Flats and West Valley water has been pumped from the trenches and evaporated. 
There is evidence of erosion of trench caps at Maxey Flats, West Valley, LASL, and ORNL.

\subsubsection{Proximity of Trenches to Ground Water and surface Water}

In humid regions, particularly in areas where the permeability of surface formations is low, the ground water lies at a short distance below the ground surface and the stream density is high. The annual precipitation at ORNL is the highest of all of the burial sites and the only significant barrier to radionuclide migration is the adsorptive property of the soil (USERDA76b).

\subsubsection{Biological Intrusion and Translocation}

Vegetation, particularly deep rooted plants, growing on the surface of covered burial trenches have accumulated radionuclides and represent a pathway for translocation of radionuclides from the trenches to the uncontrolled environment at ORN, (We79), Hanford, (Ad78, Ge77, USERDA76a), LASL (EGH77), and SRP (Ho76, Co79, DuP78c, As76). Translocation of radionuclides by deep-rooted plants is considered to be a significant long-term transport mechanism for radioactivity at Hanford (Ge77) and specifically for plutonium at LASL (EGH77). As a result, efforts are generally, taken to inhibit the growth of deep-rooted plants near the trenches.

There is a potential for small animals to intrude into buried wastes and translocate radionuclides (Ge77). At LASI elevated levels of tritium have been found in honeybees (Ri74, usGs75). The source of tritium is unknown, but it has been postulated that bees collect pollen from white clover which is abundant in a solid-waste burial area. 


\subsubsection{Proximity of Trenches to Site Boundaries}

Once radionuclides have been leached from the waste trenches and have begun migrating through the ground, the opportunity for control has been greatly diminished. Buffer zones between the actual burial trenches and the site perimeter would increase the opportunity for detection and control of radionuclide migration.

The land burial facilities operated by prime contractors to the Department of Energy are located within large reservations and consequently are buffered from surxounding areas. However, the commercial facilities have much less extensive buffer zones. A particular problem exists at the Sheffield site where only the land actually being used for disposal operations is deeded to the State of Illinois and the $200 \mathrm{ft}$. buffer zone is on privately owned land. As a result, waste may be buried up to the edge of the land controlled under the license (Bla79). This is a factor that should be considered for inclusion in criteria for shallow land burial.

\subsection{Waste}

\subsubsection{Waste Identification and Quantification}

Knowledge of the radiological, chemical, and physical characteristics of the contents of waste packages is required to facilitate the optimum disposal of solid radioactive wastes. It is difficult to describe adequately the heterogeneous mixture of materials that make up the waste packages to be buried (USGS75). However on-site measurements of radioactivity are currently considered economically prohibitive (Gat75). 
SRP began a program of routine assay of waste receipts in December 1977 and found that about 128 of the 560 packages assayed were incorrectly classified with respect to their content of transuranic nuclides (DuP78c). LASL also has a waste assay device called MEGAS (Multiple Energy Gamma Assay System) to determine the level of radioactivity in waste packages; use of MEGAS indicates that more than 908 of the waste packages from the major LASL processing facility can be buried rather than stored in a retrievable manner $(\mathrm{Ke} 78)$.

\subsubsection{Waste For:m}

Waste form is an important factor in minimizing radionuclide releases. The mobility of liquid and gaseous wastes makes them undesirable waste forms for shallow land burial. Most burial ground operators are not authorized to bury liquid or gaseous wastes, but they often receive wastes with free-standing liquids (Bl.79). Rerently Bichland and Beatty were closed by action of the respective state governors because the packaging did not meet acceptable standards for transport. With solid forms, problems have been associated with the presence of organic chelating agents in the buried waste (USERDA76a).

In gencral, waste packages dre designed to provide containment of waste during transport to the burial site and during emplasement, but not for long term containment after disposal.

\section{$\underline{2.2 .3}$ Waste Migration}

After wastes have been emplaced in trenches, the geologic formation is considered the primary barrier to radionuclide migration. Water is the principal vehicle for radionuclide transport; thus knowledge of the 
direction, depth of water table, flow paths, rate of movement, and dispersion of water coupled with the mechanisms and degree of interactions of specific radionuclides with the formation are required to understand radionuclide migration.

Ion exchange is one of the major interaction of radionuclides with the formation. However, the presence of fissures in the geologic unit may short circuit opportunities for ion exchange of radionuclides mobilized during leaching by infiltrating water. There is opportunity for water movement through fractures beneath the ORNL, West Valley, and Maxey Flats sites (Du79, De77, Pa74, Pru79). At LASL moisture has moved through joints in volcanic tuff; some of the joints are filled with montmorillonite, a clay which swells when moistened, and it is conceivable that the joints could be irreversibly expanded when moistened and thus provide a rapid pathway of movement for water (USGS75).

Mechanisms of interaction other than ion exchange may predominate and they are not always well understood (DM78, Du79). Chemical precipitation and filtration, mineral replacement, surface exchange reactions, and physical adsorption are other important interactions which have been studied. In some cases even the physical characteristics and the direction of the pathway of movement is not clearly defined (Me76, De77, USNRC76, Kel79).

Radioactive compounds with high vapor pressures, such as tritiated water, tritium gas, $\mathrm{CO}_{2}$, noble gases, and short chain organic compounds, can move in the vapor phase. Release of gaseous radionuclides through trench caps has been reported at West Valley (Mat79, Hu79, Da76). Tritium is an important radionuclide in wastes buried at SRP, and long term studies are underway to determine its rate of release to both air and ground water 
(DuP74). No migration of radioactivity has been detected at Beatty, but it has been speculated that tritium could diffuse through the soil in a vapor phase (USERDA76a). However, to our knowledge, no one has made reliable measurements of fluxes of vapor transport of radionuclids from shallow land burial facilities.

Another source of atmospheric transport exists at Maxey Flats and West Valley where water which accumulated in the burial trenches has been removed and evaporated (Me76, Mo77, Har79). At Maxey Flats tritium was the inost abundant radionuclide detected in the stack discharge from the evaporător, but 14 other long-lived radionuclides were detected, including ${ }^{60} \mathrm{Co},{ }^{90} \mathrm{Sx}$, and ${ }^{137} \mathrm{Cs}$ which were found in every sample. The consequent surface contamination does not pose an immediate health hazard (Me76), but tritium has been detected in milk and garden products from off-site locations (Mo77).

The USGS has expressed the opinion that additional information on ion exchange capacity is needed for all sites (CGO76). Such information may be useful, but would provide only a portion of that needed for understanding interactions and migration of radionuclides in the ground.

\subsection{Uperation}

\section{$\underline{2.3 .1}$ Trench Structure Management}

The backfill material covering the trenches has sagged and collapsed in some trenches at ORNL (USGS76, We79) and Maxey Flats (Me76). At ORNL the collapse has been sufficient, in some cases, to expose the buried waste. As mentioned previously, sagging of trench covers can enhance the infiltration of water into the trenches. 
Trench caps have eroded at Maxey Flats, West Valley, LASL, and ORNL and periodic maintenance is required. It has been suggested that high velocity winds at burial sites in arid climates might result in removal of significant amounts of trench cover (Ge77).

At locations such as at ORNL, Maxey Flats, and West Valley where the climate is humid and the permeability of the backfill is greater than that of the undisturbed formation, periodic sealing may be required to limit infiltration of water.

\subsubsection{Waste Receipts}

Records on waste receipts and burial ground operations for the early years of operation of the contractor facilities are generally poor (USGS7.6, NAS76, DM76b, USGS75, USERDA76b, Ge77). Relatively little is known about the identity, quantity, and concentration of contaminants associated with these wastes. Record keeping has improved, but even now disposal site operators rely on the package labels of shipping documents prepared by the waste producer to maintain records of wastes rather than performing assays of packages on receipt (Mu176, USERDA76a). As a result many records contain only general information on the form, composition, or isotopic content of the waste.

Records maintenance has been recognized as a problem at several of the burial sites. At ORNL, fire in 1961 destroyed early records (NAS76). Additionally, precise locations of some burial trenches are not knuwı (DM78). At LASL, while burial activities began in the 1940's, no records were maintained until the mid-1950's and detailed records were not kept until 1959 (USGS75). At Maxey Flats, where burial began in 1963, early records often included only a rough estimate of volume and activity (Ad78). 
Efforts to construct a comprehensive inventory of Maxey Flats wastes produced discrepancies between current and previous inventory evaluations. Differences were attributed to utilization of different primary information sources, to different handling procedures for incomplete data, and to errors in information transferral (Gat75).

\section{$\underline{2.3 .3}$ Security Control}

A cement mixer used at the solid waste burial ground at Beatty to solidify low-level liquid radioactive waste was used in the town of Beatty to pour concrete slabs at a local saloon and other private properties. The State of Nevada also found evidence that other violations had occurred over a period of several years; these involved removal of contaminated tools, equipment, and supplies from the site by Nuclear Engineering Company (NECO) employees. NECO's license to operate the burial ground was suspended but the suspension was lifted when a Federal/State investigation found no evidence that the public had received a signifirant radiation exposure and when the contaminated material was returned to the NECO site (Ma76, USNRC77).

\section{$\underline{2.3 .4}$ Safety Control (Fires)}

Fires and explosions of pyrophoric waste have occurred at both comercial and contractor sites (ISSFRnA76a, 6079, 6077, NAS76). Minor fires have occurred at SRP (Co79, USERDA76c) but no dispersion of activity was observed. Combustible material has been separated from noncombustible waste at SRP since 1973. 


\section{$\underline{2.3 .5}$ Space Utilization}

Land burial of solid radioactive waste began in an era when the operations were expected to be temporary. The operations were conducted on extensive reservations so little concern was given to minimizing use of land resources. Current methods used in the management of low-level, solid radioactive wastes result in the use of large areas of land per unit of waste. Significant improvements in the burial space utilization factor are possible. To date it has not been cost-effective to implement burial ground conservation measures as there are large reserves of land available for shallow land burial, particularly at most of the arid western sites. However, capacity for expansion is limited at ORNL, Sheffield, and LASL (Ga79, NAS76, Mul76, Bu72). The Sheffield site has been filled and plans for expansion have been abandoned ( $\mathrm{Bla79}$ ). The establishment of new burial site locations will require considerable time so consideration needs to be given to increasing the efficiency of trench use at all burial sites.

\section{$\underline{2.3 .6^{\circ}}$ Post-Operations Criteria}

West Valley and Maxey Flats are currently closed down. For these and other sites which will phased out of active burial operations, post-operations criteria for continued site maintenance need to be developed on a priority basis (USNRC77).

\section{$\underline{2.3 .7}$ Waste Package Design}

Ground contamination at Hanford has occurred on several occasions because wooden containers have collapsed after emplacement but before final 
covering (Ge77). Attention needs to be given to the selection, design, and fabrication of waste packages ( $(\mathrm{Ge} 77$ ). The use of standardized packaging would facilitate the development of improved shielding for containers and mechanized handling systems; both could reduce radiation exposures during waste handling (Mul76).

\section{4 Performance Evaluation}

\subsubsection{Monitóring of Releases}

Most of the current monitoring programs at both commercial and contractor operations are designed to monitor releases of radioactivity from the site. The monitoring programs for the contractor sites are conducted to evaluate releases from the facility as a whole rather than to identify specific releases from the burial ground operations (NAS76, Ge77, USERDA76b, USGS75). At $\dot{a}$ number of the contractor sites, other waste management activities complicate evaluation of the contribution of burial grounds to the overail releases from the facility (USERDA76b, DM78, NAS76, Ge77).

The monitoring program at Maxey Flats has not satisfied the generally accepted objectives and requirements of environmental monitoring around nuclear installations (Mo77). At Sheffield no radionuclide migration has been detected, but the groundwater monitoring wells are not necessarily placed at the optimum locations for monitoring radionuclide migration (USNRC76, CGO76).

\subsubsection{Evaluation of Burial Ground Performance}

As mentioned above, current monitoring programs are designed to 
measure releases from the overall facility rather than to provide an evaluation of performance of the burial grounds specifically (USGS75, DM78, USERDA77, NAS76, Ge77, USERDA76b). As a result, the current monitoring programs are generally not sufficient to define radiologic conditions within the burial grounds nor to provide an adequate basis for the prediction of future performance.

Additionally, there is no well-developed set of goals, criteria, and performance standards developed to use in evaluating the success of the burial grounds operations. Public relations problems have arisen because it was unrealistically anticipated at some sites (e.g. Maxey Flats and West Valley) that zero releases would be achieved; although the releases that have occurred are considered not to be a threat to public health, they do not attain the stated goal of zero release (NAS76).

Thus, there are two major needs in this area: (1) A well-defined set of goals, criteria, and performance standards and (2) monitoring programs designed specifically to monitor burial ground operations for those factors included in the performance standards.

\subsubsection{Prediction of Future Performance}

There has not been sufficient attention given to development of a systematic predictive capability. for shallow land burial operations. Most of the releases that have been detected have been related to groundwater migration and were unexpected largely because of a lack of understanding of both the chemical and hydrological mechanisms affecting radionuclide behavior. Modeling efforts to predict radionuclide behavior in the ground have had limited success because they have assumed ideal behavior of solutes in flowing systems which do not adequately simulate the actual 
chemical and hydrogeological system. Also, little attention has been given to modeling vapor transport, chemical precipitation, filtration, and other mechanisms of radionuclide trảnslocation.

\subsubsection{Need for Hydrogeologic Data}

The hydrogeologic data available at most sites is insufficient to permit the design of an adequate monitoring program (USERDA76b, Pru79, USNRC76, CGO76, USNRC76, Pa74). Geohydrological information wh1ch has been specifically noted as being lacking includes:

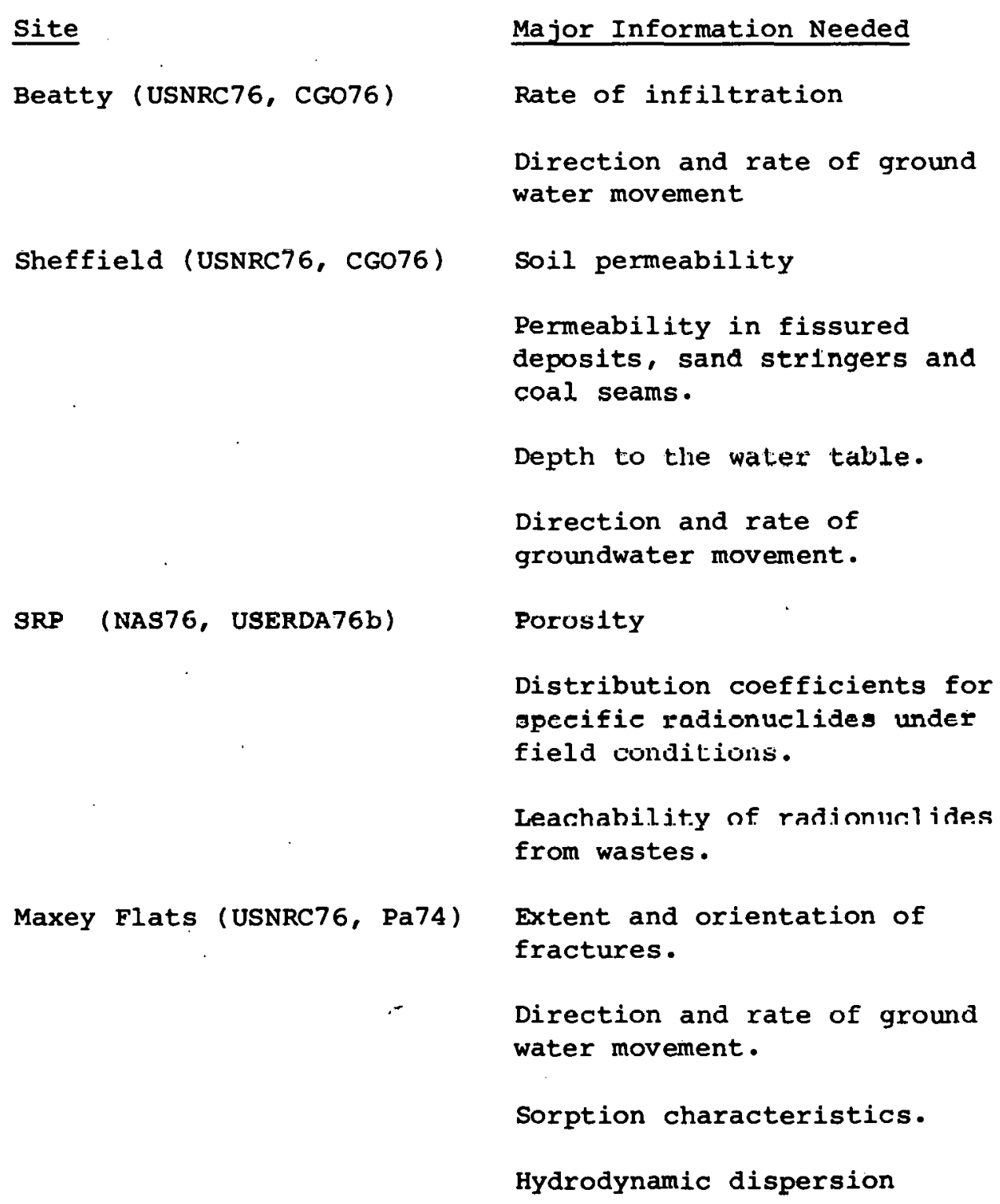


West Valley (Pru79)

ORNL (DM78, USERDA76b)

Hanford (Ge77, USERDA76b)

INEL (USERDA77) properties.

Degree of anisotropy of the glacial till.

Secondary permeability.

Water balance.

Depth to water table.

Distribution coefficients for specific radionuclides.

Saturated zone thickness in the Conasauga Shale.

Porosity .

Hydraulic conductivity of different layers.

Hydrodynamic dispersion properties.

Detailed 1ithology.

Presence and extent of solution channels.

Detailed lithology below the burial grounds.

Hydraulic conductivity in saturated and unsaturated zones.

Hydrodynamic dispersion properties.

Distribution coefficients for specific radionuclides.

Detailed lithology and character of alluvial deposits. 


\subsection{TECHNICAL ISSUES}

In Section 2.0 a review of the problems experienced in shallow land burial operations were discussed in generic groupings. Section 3.0 is devoted to discussing the technical issues related to these problems which require further research and development. Resolution of these issues is necessary for the development of improved management practices for shallow land burial. The research and development programs will also provide useful linfömätion for remedial actions at currently operated sites. Each issue is discussed in terms of several important considerations. These considerations include relating the issue to a particular problem or set of problems identified at operational facilities, specifying the information needed, citing some recent or current research and development efforts that relate to issue resolution, and establishing aspects of the issue for which further research and development are needed.

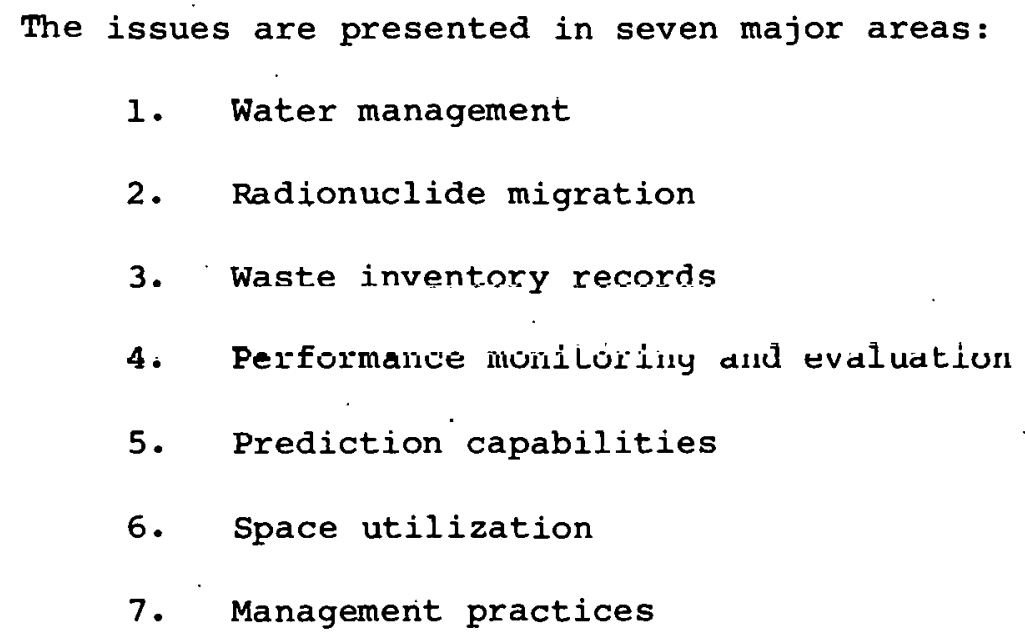




\subsection{Water Management}

As mentioned in Section 2.1.1 the most serious technical problems in shallow land burial are related to water management. The most common ways water comes into contact with the waste are from infiltration of precipitation through the trench caps and/or walls or from erosion leading to the exposure of the buried waste.

Both infiltration and erosion can be controlled by water management practices. Erosion connt.rnl prartices include a good veqetative cover, a permeable cap, and shallow slope; whereas measures for infiltration control include limiting vegetation, an impervious cap, and a high slope to promote rapid drainage. Hence, management practices that reduce erosion may enhance infiltration, and vice-vexsa. Selection of a suitable burial site management program must consider a balance between the control of infiltration and erosion.

\subsubsection{Management to Reduce Trench Infiltration}

The control of infiltration of water into trenches is a major step in the prevention or minimization of contact between water and buried waste. Infiltration that occurs (1) promotes further infiltration by damaging the structural integrity of the trench cover and trench contents and (2) provides a vehicle for migration of the waste. The objective of this technical issue is to evaluate those factors which influence the infiltration of water into waste burial trenches.

A number of practices may be used to reduce infiltration of water into trenches including (1) use of sealants for caps and sidewalls of trenches, 
(2) in situ compaction of wastes, (3) injection of solidifying materials into trenches (4) mounding and compaction of trench caps, (5) diversion of surface and ground water, and (6) maintenance of trench caps. A Dames and Moore study (DM76b) has provided an engineering evaluation of a number of practices for controlling infiltration into trenches at the west valley site. Modifications in trench covers which were evaluated include: asphalt caps; cap liners of polyvinyl chloride (PVC), butyl rubber, chlorosulfonated polyethylene (CSP), ethylene propylene rubber (EDPM), chlorinated polyethylene (CPE), hydraulic asphalt concrete; a bituminous seal; and a clay layer. Synthetic liners were judged to be capable of the greatest reduction in trench cover infiltration. However, the asphalt caps showed the highest ratio of anticipated reduction of infiltration of water into trenches relative to annual cost.

The Dames and Moore study also evaluated the reforming of the soil cover by mounding and compaction and suggested that this technique could reduce infiltration by a factor of 2 to 5 at West valley. Reduction of infiltration from mounding and compaction is less than that anticipated for synthetic liners, and its cost-effectiveness is less favorable. The Dames and Moore study also concluded that while pumping accomplished the greatest reduction in trench water, it was by far the least cost-effective, and was a favorable management option only on a short-term basis.

The Dames and Moore report provides a first step in comprehensive evaluation of water management to control infiltration. A literature review should be made of field experience at both radioactive and non-radioactive burial facilities. Much of the experience at operational facilities may not be reported in the literature; thus, interviews or questionnaires may be necessary to retrieve the desired information. The 
findings from such a review and from the Dames and Moore report should be used to identify techniques that have technical promise or which have been useful at specific sites. These techniques should then be subjected to experimental examination in field situations with particular attention given to imposing both controlled conditions to enable intercomparison of techniques and ranges of anticipated conditions at sites of potential application. The anticipated conditions should include not only the native hydrogeological characteristics of the site, but also the changes in parameters that may occur from operation of the facility or from nearby construction.

\subsubsection{Management to Reduce Trench Cap Erosion}

Control of trench cap erosion is also needed to minimize the contact between water and the buried waste. Erosion may damage the structural integrity of the trench cap (1) promoting infiltration and (2) exposing waste for subsequent transport by water and air. The objective of this technical issue is to identify and quantify those factors which influence the erosion of trench caps.

A number of management practices should be evaluated for their effectiveness in erosion control; these include use of (1) various types of vegetative onver, (2) contouring, (3) diversion channels for control of surface water flow, (4) various types of physical materials for trench caps, and (5) trench cap maintenance. In addition to providing short-term erosion control, consideration should be given to their ability to remain stable over long periods of time and to provide protection against intrusion by deep-rooted plants and by small burrowing animals. 


\subsubsection{Management Balance in Infiltration and Erosion Controls}

A suitable burial site water management program must balance control of infiltration and erosion. There is no established rationale for arriving at this balance.

The objective of this technical issue is to develop the information and rationale to enable operators of burial facilities to select the appropriate balance in control of infiltration and erosion which is optimum for the range of conditions anticipated at the site.

The adoplion uf uptimum practices forr control of infiltration at a burlai site may be at cross purposes with optimum control of erosion. Good water management practice must consider the effects of possible practices on both infiltration and erosion and arrive at the policy best suited for optimum water management at the site. This balance will likely vary from site to site, reflecting differences in hydrology, climate, topography, soil mechanics, qeoloqy, etc.

of additional concern in arriving at management policy is the consideration of off-normal weather conditions. For locales where abnormal weather conditions are dramatically different from normal occurrences, management policy may need to be weighted toward a ronnern for the abinomal.

In summary, burial ground operators must control both infiltration and erosion. The choice of techniques and the balance of control depends on a number of site-specific factors which vary in time. Information which incorporates site-specific data needs to be developed and evaluated in Măking appropriate managerial decisions. 


\subsection{Radionuclide Migration}

Radionuclides follow the general paths of movement of the transporting fluid but normally move at a slower rate due to interactions with the formation through which they are moving. The major vehicle for transport of radionuclides in the ground is the convective movement of groundwater. When water is the transporting vehicle, one must have knowledge of the direction, flow path, rate of movement, and dispersion as well as the mechanism and degree of interactions of specific radionuclides with the formation in order to predict radionuclide migration.

In the absence of moving groundwater the rates of movement of non-gaseous radionuclides by molecular or ionic diffusion are very small. However, for some gaseous or volatile radionuclides, transport in the vapor phase may be important. Diffusion coefficients for gaseous radionuclides in air are on the order of 0.1 to $0.5 \mathrm{~cm}^{2} / \mathrm{sec}$. Consequently gaseous radionuclides may move appreciably due to molecular diffusion. For example, radon, a noble gas daughter in the uranium decay series, and tritium may be expected to migrate significantly in the vapor phase. Carbon-14, in the form of $\mathrm{CO}_{2}$ or short chain hydrocarbons may also move in the vapor phase. The magnitude of such transport should be established by field measurements.

Normally, one assumes that the solids of the geologic strata and that fraction of the radionuclides adsorbed by them remain stationary over the time of concern. However, fine particulates can move through porous media and appreciable movement can occur if the formation contains channels. over very long time periods, say several millenia, even the solid matrix can move significantly because of erosion or tectonic events. 


\subsubsection{Groundwater Movement and Dispersion}

The objective of this issue is to facilitate the measurement and compilation of geohydrologic information needed to develop predictive capabilities for radionuclide migration and for the design of environmental monitoring programs for performance evaluation.

At most sites where shallow land-burial of radioactive waste is conducted, at least part of the geohydrological information needed to provide a suitable basis for predicting radionuclide migration is lacking (USNRC76, CGO76, Pa74, Pru79, DM76a, USERDA76b, USERDA77, (fe77). However, most of the major contractor facilities have ongoing programs for field studies of groundwater movement, particularly at Hanford where soil-moisture relations have been studied extensively for a number of years (Is78, In76a, RHO77).

Less effort has been devoted, until recently, to measuring site-specific hydrodynamic dispersion characteristics, although the importance of such information has been recognized for some time (Or56). Even in a linear flow system there is a distribution of flow times for a tracer from its point of injection to its point of emergence. In multi-dimensional flow system dispersion is accentuated because the various flow paths have different lengths and, consequently, different. hydraulis gradients. In natural systems dispersion is further enhanced because of the non-uniformity of the hydrologic characteristics of the conducting medium. Those strata having a higher permeability conduct a greater proportion of the total flow. As a result, dispersion coefficients measured under field conditions are nearly always larger than those measured in the laboratory, often by several orders of magnitude. Thus it is essential that site specific measurements be made. 
Dames and Moore (DM76a) has made a detailed assessment of the geohydrologic information needed to develop predictive capabilities and groundwater monitoring programs and has summarized the data available at ORNL, Hanford, SRP, INEL, and LASL. Important gaps in geohydrologic data are listed on a site-by-site basis in section 2.4.4 of this document.

Further efforts are needed to assess just what information is needed and the format for compiling the information. The work by Dames and Moore (DM76a) could serve as the base. This working paper should then be reviewed in detail by experts who will use the information to assure that all significant elements are included and in the appropriate format. The choice of format depends to a great extent on the mathematical models to be used for predictive capability.

\subsubsection{Mechanisms of Radionuclide Interactions in the Ground}

As radionuclides move through the ground they may interact with the formation in a number of ways. The major reaction of radionuclides with minerals in the ground is usually cation exchange. (Other mechanisms of interaction have been noted in Section 2.2 .3$.$) Ion exchange reactions in$ soil materials have been investigated extensively since 1850 when Thompson (Th50) and Way (Way50, Way52) found that dissolved salts from manures were removed from solution as the salts percolated through the ground, displacing an equivalent amount of calcium from the soil.

Ion exchange is particularly characteristic of clay minerals and zeolites because their small particles sizes give rise to large specific surfaces which are available for geochemical reactions. Due to broken bonds at the termination of the crystal, isomorphic substitution of lower valence cations within the mineral structure, and the dissociation of 
surface hydroxyl groups, electrical charges arise at mineral surfaces.

Regardless of the mechanism of interaction, the presence of fissures in the geologic unit may reduce the efficiency of contact between the solute in the moving water and the earth material and reduce the degree of interaction (Du79).

3.2.2.1 Effects of chemical conditions on the chemical and physical properties of specific radinuclides. The objective of this technical issue is to elucldate the effect of chemical conditions on the chemical and physical properties of specific radionuclides so that the mechanism and degree of their interactions in the ground can be predicted for the spectrum of conditions likely to be encountered in shallow land-burial conditions.

A considerable amount of effort has been devoted to laboratory studies on the interaction of radionuclides with soil materials; for example, the review of actinide-sediment reactions by Ames, et al. includes over 800 references in an annotated bibliography pertaining just to the actinides (Am76). However, much more information is needed--particularly for chemical. conditions which more closely simulate those encountered in the field, including changes that will occur during the required period of containment. Quite often the mechanism of the interaction is not well known, making it difficult to extrapolate behavior under different conditions or even to make adequate predictions of radionuclide migration. In ion exchange the distribution coefficient is affected by the selectivity factor, the exchange capacity, and the concentration of competing cations (Or56, Fri76, In76b). The selectivity factor in turn. depends on the crystal structure of the mineral, the nature of the 
exchanger surface, and the nature of the competing cations (Du79, Or56, Ro73). For ion exchange involving cations of unequal valence, those with higher valence are generally adsorbed more strongly than those of lower valence.

The $\mathrm{pH}$ of the system has three major effects on ion exchange. First, the $\mathrm{pH}$ reflects the concentration of hydrogen ions; hydrogen is a very strongly adsorbed cation and is very competitive, even for exchange sites which arise due to isomorphic substitution within the mineral lattice. Second, some of the exchange sites on mineral surfaces are weakly acidic and their tendency to become dissociated and add to the net electrical charge is $\mathrm{pH}$ dependent; the higher the $\mathrm{pH}$ the more complete the dissociation and the higher the exchange capacity. Finally, the insoluble salts are commonly salts of weak acids and their solubility is pH dependent. Ordinary soil has the power to buffer changes in pH (In76a).

Oxidation-reduction conditions are another major factor affecting the solubility of many slightly soluble salts (Du79, Am76). The oxidation-reduction conditions are especially important for elements in the various transition series as they may exist in a number of different oxidation states. This has a marked influence on their chemical and physical properties and therefore upon the nature and extent of their interaction with soil materials. Ruthenium behavior in the soil is a classic example of the complications that can occur as it can exist in nine oxidation states.

Mineral replacement and surface exchange reactions occur under conditions similar to those leading to interstitial precipitation except that the reaction takes place predominantly at the surface of solid minerals (Ro73). Partial dissolution of the surface of slightly soluble 
minerals may occur followed by the formation of a new surface coating with co-precipitation of radionuclides on the newly formed surface. If the waste stream is in chemical equilibrium with the mineral system, there is no chemical precipitation at the surface but radionuclides may exchange with similar ions at the surface of the mineral.

Physical adsorption may occur when radionuclides are in a form that does not have a net electric charge. The forces for adsorption in such cases may consist of hydrogen bonding, ion-dipole interactions, or dipole-dipole interactions. These attractive forces tend to be weaker than those of ion exchange or mineral replacement.

Some radionuclides may form very stable complexes with organic or inorganic ligands (Du79, Ch76, Ro73, P177, Mea78). PNL has prepared a detailed review of the stability of organic complexes of nickel and has identified several isotopes that may migrate from shallow land burial facilities as orqanic complexes (P177). Orqanic complexing aqents, such as EDTA, are used in decontamination operations and may be present in wastes sent to buxial grounds. At ORNL cobalt-60 has been found to be chelated with EDTA in groundwater migrating from the waste trenches (Du79, Mea78). Although the stability of the ${ }^{60} \mathrm{Co}$ (III)EDTA complex is not sufficient for it to be formed under environmental conditions because of the presence of competing cations, its presence can persist for rather long periods of time because of slow reaction kinetics. Detergents, surfactants, and polyelectrolytes have also been studied with respect to their influence on radionuclide adsorption ( $\mathrm{Ro} 73$ ).

Biological activity may give rise to a wide spectrum of organic salts and acids capable of forming stable complexes. The complexation may change the electrical charge and alter the likelihood of ion exchange. Biological 
activity may also convert the radionuclides from a solute to a gas, thereby enhancing its mobility.

In the early stages after waste emplacement, oxygen is available to provide aerobic decomposition of organic constituents to form carbon dioxide, water and nitrates (Thomp79). As the oxygen supply is depleted anaerobic decomposition may yield methane, carbon dioxide, water, organic acids, and other products. These products of decomposition may have a major influence on the mobility of critical radionuclides.

All of the major laboratories have continuing programs to study the mechanisms of radionuclide interactions in the ground. The basic studies on mechanisms of the interactions should continue but with more emphasis on the spectrum of conditions likely to be encountered in the field. The effects of $\mathrm{pH}$, oxidation-reduction conditions, complexing agents, and biological activity on the behavior of specific radionuclides should be studied. It would be impossible to study all permutations for all radionuclides; thus, a list should be made of those radionuclides present in shallow-land burial operations which pose the most significant radiological health hazards and these should be given priority for detailed study. It is important that attention be given to the kinetics of reaction mechanisms as well as to equilibrium conditions. Many of the transitions from one oxidation state to another or the breakdown of a metastable complex may require periods of time sufficient to permit considerable migration under field conditions.

3.2.2.2 Effects of physical conditions on radionuclide transport. The objective of this technical issue is to measure and evaluate the effects of physical conditions on radionuclide trársport. 
Physical factors can have a major influence on the degree of interaction between radionuclides and the geologic media into which they are disposed. The effects of factors, such as physical transport of fine particles, flow through fissures and channels, degree of saturation, and vapor phase transport, need to be thoroughly understood.

Even though the adsorption of a radionuclide in a particular geologic formation is predicted to be large, the lack of opportunity for the percolating solution to interact with the formation ran lead to slgniflcanily more transport than expected (Du79, Fri76, Ch76).

Soil has the power to buffer changes in $\mathrm{pH}(\operatorname{In76a)}$ and if the waste solution is neutralized, chemical instablility may result and colloidal particles may be formed which include radionuclides as co-precipitates. The geological formation may then act as a filter to remove these small particles; the efficiency of filtration is dependent on the distribution of pore sizes as compared with the size of colloidal particles formed (Ch65) and the residual electric charge on the colloids. Significant migration of some radionuclides can occur as a result of particle migration (Fri76, Ch76). For example, studies at ANL indicate that although the bulk of Pu and Am are very tenaciously retained by tuff, basalt, or limestone, a fraction of the $\mathrm{Pu}$ migrated at a much more rapid rate; it was conjectured that the rapidly migrating form was a polymer (Fri76).

In most cases radionuclide filtration is greatest at the point of entry into the geological formation and tends to decrease exponentialiy with distance of penetration. Precipitation and filtration can eventually lead to clogging of the formation and reduce the rate of groundwater movement.

Laboratory studies on interactions between radionuclides and the soil 
are usually conducted under saturated conditions. PNL has compiled a bibliography on radionuclide transport in unsaturated groundwater systems and is developing models and compiling field data on transport in unsaturated media (P177, RHO77). Studies of migration of tritiated water, ${ }^{90} \mathrm{Sr}$, and ${ }^{60} \mathrm{Co}$ indicate that their retention in unsaturated media is at least as effective as in saturated media (In75).

Gaseous radionuclide releases through trench caps have been reported at West Valley (Mat79, Hu79, Da76), but little recent effort has been devoted to detailed laboratory studies. The U.S. Atomic Energy Commission sponsored work on the behavior of radioactive gases discharged into the ground several years ago (Ja66) but most of the recent interest has been related to emanation of radon from uranium mill tailings. LASL and PNL have current programs to study vapor phase transport of radionuclides.

Laboratory studies are needed on:

1) The effect of degree of saturation on radionuclide adsorption;

2) Physical transport of fine particles through porous and channeled media;

3) Sorption of solutes from solutions flowing

through fissures and channels; and

4) Vapor phase transport of radionuclides.

In addition, field measurement should be conducted to verify the significance of these transport conditions and the results should be considered in the development of predictive models.

\subsubsection{Site Specific Measurements Related to Radionuclide Migration}

The migration of radionuclides in the ground is difficult to simulate 
under laboratory conditions because a large number of factors may affect radionuclide movement and dispersion. Generic measurements should be conducted using geologic materials and chemical conditions representative of specific sites. Even these precautions are not adequate to fully simulate field conditions as the parameters affecting migration may vary both in time and space.

3.2.3.1 Laboratory measurements related to radionuclide migration. The objective of Llis technical 1ssue is to develop information on site-specific adsorption coefficients for radionuclides of signtflcance in shallow land-burial operations.

Available information should be compiled in a standardized format after it has been verified that the measurements were made under conditions simulating those anticipated at the site. This may require collection of groundwater samples from the site for chemiral analysis, with particular analytical attention given to those chemical factors which are known to have a significant influence on the adsorption of various radionuclides. When information is not available for radionuclides of significance in shallow land-burial operations, laboratory measurements should bc made.

3.2.3.2 Field measurements of radionuclide migration. The objective of thls Eechnical issue is to collect information on the actual migration of radionuclides under field conditions to verify the understanding of the mechanisms of radionuclide migration and predictive models.

Radionuclides moving under field conditions are subject to many more influences than can be simulated in the laboratory. Hydrodynamic dispersion is usually orders of magnitude greater than that measured under 
laboratory conditions. The presence of fissures, channels, and zones of widely divergent permeability can have a major influence on the movement of water and its solutes. Also the degree of interaction between the waste solution and the formation may be much less than that experienced in the laboratory.

At Hanford only traces of ${ }^{90} \mathrm{Sr},{ }^{137} \mathrm{Cs}, \mathrm{Pu}$, rare earths, and transition metals have been detected moving into the saturated zone (Ro73). Migration of ${ }^{137} \mathrm{Cs}$ and ${ }^{90} \mathrm{Sr}$ below the Hanford cribs is in good qualitative agreement with laboratory solumn הata (Rn7.3). On the other hand, at oRNL ${ }^{137} \mathrm{Cs}$ was found in a fracture below Solid waste Disposal Area 5 at a depth well in excess of that anticipated (Du79, Key76).

At Chalk River the movement of ${ }^{137} \mathrm{Cs}$ and ${ }^{90} \mathrm{Sr}$ was measured in ground water following discharge of liquid radioactive wastes into the ground (Par62, Par76). The groundwater moved at a rate varying from 0.3 to $0.5 \mathrm{~m}$ ( 1 to $1.7 \mathrm{ft}$ ) per day. In the first 5.5 years, ${ }^{137} \mathrm{Cs}$ moved $85 \mathrm{~m}$ (276 ft) and ${ }^{90} \mathrm{Sr}$ moved $170 \mathrm{~m}$ (560 ft); in the following year ${ }^{137} \mathrm{Cs}$ moved $2.1 \mathrm{~m}$ ( $7 \mathrm{ft})$ and ${ }^{90} \mathrm{Sr} 4.6 \mathrm{~m}(15 \mathrm{ft})$. The reduced rate of migration was considered to be due to dispersion and dilution of the original salt content of the waste. The author considered the adsorption coefficient for ${ }^{90} \mathrm{Sr}$ to be anomalously high because the waste solution was originally acidic. However it is likely that the acid had been neutralized by the buffering action of the formation.

The concentrations of radionuclides migrating from shallow land-burial facilities are usually low and the rates of movement slow, making it difficult to obtain an accurate depiction of radionuclide migration in the field. Also, at many sites liquid wastes have been discharged into the ground near shallow land burial activities and may mask the results. 
Nevertheless, efforts should be made to compile the available information on actual radionuclide migration at the various sites and to make periodic surveys to monitor changes in the spatial distribution with time.

\subsection{Waste Records}

The handling and disposal of waste radioactive material presents a potential for radiation exposure of operational personnel and a possible source of radionuclide release to the environment. The development and implementation of a safe waste disposal policy requires an understanding of the extent of the potential hazards. Thus, the radiological, chemical, and physical characteristics of the contents of the waste packages must be known and recorded.

During the early periods of shallow land burial operations, disposal records were inadequate for current needs. Reconstruction of deficient past records of waste disposal requires techniques for locating and identifying wastes. To assure that future records are maintained adequately requires establishment of techniques for the accurate characterization of the waste upon packaging and techniques for the verification of waste character at the receiving site.

\subsubsection{Waste Characterization at the Waste source}

The most thorough characterization of the waste can be made at the waste source. The waste producer should be aware of the types of information needed by the disposers, be equipped to make the necessary measurements in a heterogeneous mixture, and be motivated to be accurate in the characterization. 
While the process of characterization at the waste source is outside the concern of this report, the identification of the information needed by the operator of the disposal facility to ensure safe waste management is an appropriate concern. Sufficient information about the waste must be available to the waste facility operator so that potential hazards during handling may be evaluated and minimized and so that short and long-term performance after emplacement may be projected.

\section{3 .2 Waste Characterization at the Receiving Site}

In the absence of suitable characterization or verification of contents by the waste producer, waste characterization could take place at the receiving site. Waste properties which influence options for disposal should be measured. Thus, there is particular concern for long-lived radionuclides, radionuclides with high radiotoxicity, and radionuclides with high potential mobility. Methods to verify the physical characteristics of waste receipts and procedures for remedial action are needed.

The MEGAS instrumentation at LASL was developed to verify the transuranic content of waste packages to assure their proper disposition (Ke78). An instrument to assay the content of transuranic radionuclides in waste packages has also been developed and applied at SRP (DuP78C). Passive $\mathrm{X}$-ray spectroscopy has been developed at INEL for determining $\mathrm{Pu}$ in waste $(\mathrm{Cl} i \% 2)$

Further instrumentation research is needed for assay of TRU at the $10 \mathrm{nCi}$ per gram level in waste packages. Since standard containers are not required, these instruments should be able to assay the content of packages of unusual dimensions or shape. Instrumentation and associated facilities 
are also needed for assay of beta-gamma activities in waste packages.

It should be observed, however, that characterization techniques that leave the waste package unopened provide little information for dealing with the potential (or eventual) hazard resulting from rupture of the waste package after emplacement. Understanding of this hazard requires a more thorough characterization of the chemical and physical characteristics of the waste such as those which influence radionuclide solubilization, complexation, etc. While the opening, sampling, and analysis of waste packayes may enable à straightforward representation of waste character, it may also introduce an additional potential for radiation exposure to operational personnel and requires that suitable personnel protection measures be identified and instituted.

Guidance is also needed by site operators for dealing with waste receipts that do not meet the criteria for transport or disposal.

\subsubsection{Waste Characterization in the Field}

As a result of inadequate records, there is a considerable need for the reconstruction of records for waste already emplaced. Gaps in records of burial activities are not uncommon, as noted in section 2.3.2.

Hanford has a program for the development of field instrumentation for logging of the physical and radiochemical characteristics in the waste disposal areas (RHO77). Geophysical probing of the Hanford site has involved drilling and sample collection, metal detection, acoustical examination, ground penetrating radar, infrared imagery, and a number of other techniques (Ph77, E175). Geophysical logging has been conducted at ORNL by the USGS (Key76).

The degree of detail obtained in a field assay is related to the 
number of techniques applied and to the spatial intensity of application. The cost of the assay is similarly related.

Instruments and techniques need to be developed for in-situ characterization of buried waste. It is important before embarking on an extensive development program to determine which specific physical, chemical, and radiological characteristics need to be measured to improve existing knowledge of waste inventories, of the spatial distribution of the waste, and of its radioactivity. Instruments and techniques should be developed and field tested to demonstrate instrument mobility, durability, and reliability. The techniques should not have an adverse effect on waste containment.

\subsection{Performance Monitoring and Evaluation}

Monitoring at most burial sites has been concerned historically with measurement of the migration of radionuclides from burial facilities into the public sector. Accordingly, monitoring networks have been designed to measure radionuclide release at the perimeter of either the burial ground or of the reservation. The type of information generated by such monitoring does not necessarily enable burial site performance to be evaluated with respect to migration of radionuclides from the emplaced waste. Perimeter monitoring is poorly suited for representing patterns of radionuclide movement between the waste trench and the perimeter since it may overlook pathwayg occurring within that region.

Performance evaluation of burial ground facilities requires a carefully designed monitoring system, the establishment of criteria for evaluat.ion, and the develonpment of terchnolngy for monit.nring. 


\subsubsection{Conceptual Design of Monitoring Systems}

The objective of this technical issue is to develop guidance for the design of monitoring systems for shallow land burial of radioactive wastes.

Guidance needs to be developed and provided to the site operator for the design of a suitable monitoring system for performance evaluation. The guidance should have three major considerations. First, the important pathways of radionuclide movement must be identified. Second, measurement locations must be established which will facilitate the detection and characterization of radionuclide movement. Third, measurement must be statistically sound for accurate depiction of radionuclide movement and the consequences.

The identification of important pathways of radionuclide movement from the burial trench is a complex process and requires an understanding of the operations, of the disposal environment, i.e., the geology, meterology, topography, etc., and of the waste character. An understanding of the environment is needed to identify avenues and rates of migration. Waste characterization is needed to evaluate the mode of transport, chemical and physical form of significant radionuclides, and mechanisms of attenuation resulting from interaction with the environment. The disposal environment, and the waste character, will vary from site to site; thus, important migration pathways are also likely to vary. Assistance in identifying pathways needs to be available to the site operator. For example, at the humid locations of West Valley and Maxey Flats the major pathways of concern for radionuclide migration involve saturated subsurface water movement and its intersection with normal surface flow. For arid regions, unsaturated flow and vapor phase transport are much more important. Recent 
work by Leddicotte, et al. (Led77) has compared radionuclide migration through a number of pathways for a hypothetical humid and an arid site. Other recent literature has addressed migration pathways at specific sites (Da76. Br77, USERDA77, DM78).

Unlike the monitoring for releases of radionuclides from a site, monitoring to evaluate performance requires that measurements be made at locations in addition to the perimeter. A monitoring network for performance evaluation should reflect the anticipated major pathways of migration, as determined above, and should collect information to represent the spatial and temporal distribution of radionuclides. Perhaps the most extensive current monitoring program at a burial facility is installed at the Savannah River Plant (As76, Ho76, DuP74, DuP75, Dup78b, DuP78c). A recent Dames and Moore report (DM78) has discussed the difficulty associated with conceptualizing a monitoring program for a burial region where the flow is unsteady, anisotropic, and nonhomogeneous.

The development of a suitable program for monitoring performance evaluation is an iterative process. The system cannot be designed until sufficient information is available to predict the significant pathways and rates of radionuclide migration. Measurement points should be clustered around these significant pathways and as further information becomes available from the monitoring programs, the design of the system should be modified.

\section{4 .2 Development of Performance Standards}

The objective of this technical issue is to develop performance standards and measures of performance against which to evaluate the acceptability of burial ground performance. 
Although the USEPA and the USNRC have responsibility for establishing general levels for environmental protection and for radionuclide release limits respectively, the Department of Energy (DOE) is responsible for assuring that these limits are met, both for current and projected releases. Thus, development of performance standards and measures of performance should be considered a valid exercise in the DOE waste management program.

In the absence of generally accepted performance standards, various levels have been suggested. A Hanford report states that they shift disposal operations to a different location when groundwater concentrations at a working site reached $0.10 \mathrm{MPC}$ (Ro73). Ledd1cotte, et al. (Led77) have derived limits on quantities of specific radionuclides allowable for burial ground disposal using an assumed limit of 0.10 MPC for releases into the uncontrolled environment.

Until environmental protection standards and limits of release specific to shallow land burial have been established by EPA and NRC, assistance should be given each facility in the development of performance standards for their operations. The development of specific site performance standards should be coupled with the establishment of remedial actions to be implemented when "trigger" levels are reached. The establishment of remedial action plans for each site would be an important step in gaining public confidence in burial operations. A well-developed set of performance standards, measures of performance, and graded action levels would also facilitate review of the acceptability to the public of facility operations. 


\subsubsection{Development of Technology for Monitoring}

The objective of this technical issue is to develop improved instruments and the procedures for monitoring. Most of the major DOE contractor facilities have programs to develop and test field instruments and monitoring procedures. Hanford is conducting an extensive program for application to burial facilities (Fre71, Ph77, El75). Brookhaven National Laboratory has developed anoxic sampling procedures for Maxey Flats (Col77). Considerable monitoring experience has been gained at the Savannah River Plant (As76, Ho76).

An assessment should be made of techniques and instruments currently in use and those being developed for monitoring. The assessment would serve as a guide for establishing additional monitoring research needs. Particular attention should be given to measurement accuracy and to in situ devices capable of continuous measurement.

\subsection{Predictive Capabilities}

After wastes have been emplaced in trenches, the geologic formation is considered to be the primary barrier to radionuclide migration. Water is the principal vehicle for radionuclide transport and most efforts in developing predictive models for radionuclide movement from burial grounds have involved modeling of groundwater and solute movement. Most models have been based on ideal behavior of ion exchange in groundwater filow systems which can be described in simple mathematical terms. Less attention has been given to vapor transport and other mechanisms of radionuclide translocation.

At Maxey Flats and West Valley water has been pumped from burial 
trenches and evaporated. This could represent a significant pathway for environmental dispersion of radioactivity.

A systemmatic predictive capability of potential releases from all operations involved in shallow land burial needs to be developed and verified by comparison with past and current performance evaluations. This will require identification and quantification of significant transport pathways and development of an understanding of the specific mechanisms involved. The sub-models used to depict the various pathways should credibly reflect the mechanisms involved and the range of parameters likely to be encountered at specific sites.

\subsubsection{Development of a Comprehensive Model to Depict All Significant} Pathways of Radionuclide Transport from Burial Ground Operations

The objective of this technical issue is to identify significant mechanisms and sources of release of radioactivity in the various phases of burial ground operations and to develop a quantitative estimate of the ranges of probable releases and impacts. All operations involved in shallow land burial covering the period from the time of receipt of waste shipments throuqh the time in which radioactive decay reaches innocuous levels, should be reviewed with respect to potential sources and pathways of release.

Wheeler et al. (Wh77) have considered a suite of potential acuice and chronic release mechanisms for plutonium from the burial grounds at LASL and have examined a number of subsequent pathways for environmental redistribution and exposure to man. Leddicotte et al. (Led77) have also considered a number of important pathways and modes of exposure to man from shallow land-burial sites in deriving suggested limits on the quantities 
and concentrations of radionuclides suitable for shallow land burial in both humid and arid environments. Inoue et al. (In74) have also examined a number of environmental pathways that must be considered in selection of sites for shallow land burial. Hanford has compiled codes for radionuclide transport and dose calculations to assist in the overall evaluation of waste management program (Par62). Although water is considered to be the primary vehicle for radionuclide migration from shallow land-burial facilities, other pathways of importance need to be identified and their significance established.

An overall evaluation should be undertaken to establish priorities for further research and development related to radionuclide migration. The critical radionuclides in wastes should be identified on the basis of such factors as quantities, concentrations, radiotoxicity, environmental mobility, and persistence. Potential acute and chronic release mechanisms should be identified and ranges established for their probabilities of occurrence for the time period the waste remains hazardous. Further work should describe and quantify the probable ranges of the rate of environmental transport and exposure for a broad spectrum of pathways. Systematic evaluations for the full chain of considerations would then identify those radionuclides and pathways which are likely to be most important so that emphasis can be placed on their quantification in subsequent research and development.

3.5.2 Development of Models for Transport by Specific Environmental Pathways

The objective of this technical issue is to develop and verify models for the transport of radiunuclides and radiation cxpocure for those 
pathways which are significant for shallow land burial.

Attention should be given to all significant pathways identified in the effort described in Section 3.5.1. Hanford is evaluating biological cycling and transport (Ph77, Ro73, E175), and has compiled codes for radionuclide transport and dose, calculations for various pathways important in waste management (P177).

A number of pathways can eventually lead to exposure of man. The more direct pathways of exposure include the use by man or animals of contaminated groundwater for drinking or the uptake of radionuclides from the soil into the food chain. Lateral migration can result in contamination of adjacent groundwater and surface water. 'If a contaminated region includes a productive aquifer, water uptake for irrigation may result in exposure. A less likely; long-term exposure pathway could result from denudation of the cover formation followed by surface erosion of the contaminated zone by wind or water.

In many field situations the subsurface flow geometry is not simple and modeling is complicated because the porous medium may be anisotropic or non-homogeneous, or both. A formation is anisotropic if the permeabilities are different in different directions and non-homngenenus if the pers meab1lity is difterent at different points (IAEA65). This makes analytical solutions difficult, at least, and often impossible.

Models for predicting radionuclide migration have been developed by combining information on fluid flow through porous media with appropriate corrections for dispersion and retardation of the radionuclides. The level of sophistication of the models and the emphasis given to the various factors depends markedly on the purpose of the model and the interests of its developers. 
"Discontinuous models" for depicting radionuclide migration in linear flow systems were developed by Thornthwaite and Mather (Tho59), Reiniger (Re70), and Frissel and Poelstra (Fr67) among others. Equations describing inputs and outputs for each compartment can be programmed into computer language. When considered serially, the solution consists of an expansion of the binomial theorem. Thomas (Thom44) was the first to solve the differential equations describing solute migration in linear flow systems. Heister and Vermeulen (Hi52) and Glueckauf. (G155) also developed equations describing such behavior. The solutions of the equations yield an error function which is similar to expansion of the binomial theorem.

Probably the most sophisticated models are those based on ground water flow. Muskat (Mus46) has developed analytical models for systems having relatively simple geometry. The increasing use of analog, digital, and hybrid computers has made it possible to develop numerical solutions for groundwater flow regimes, even for complex conditions (Ost63, Ne63, PNL65, Du79, Du76c, Ah77, Sc77, Sc75, Red70). However, in anisotropic and heterogeneous formations, the input parameters for models are difficult to quantify prior to operation of a waste disposal facility (DeL56), and intensive on-site field investigations are needed at any site before mathematical models can be applied (DeB74).

Evaluations of the mechanisms and models for moisture movement are being conducted at Hanford where several mathematical models have been developed (E175). For example, the Multicomponent Mass Transfer Model is currently in its third generation and it has been verified by comparing results from the model with known closed-form solutions; an error and sensitivity analysis has also been performed (Ah77). Field measurements are being used to provide input information on the model parameters and to 
verify groundwater migration models (Fe63, Fu79, Ro73, Du76c, Is78, Ph77).

Recent studies at Argonne National Laboratory have been devoted to development of models to depict migration of plutonium and americium through porous media, crushed rock, and fissures (Fr76).

Development of mathematical models for radionuclide migration seems to be more advanced than current ability to verify the models with field data. Rates of radionuclide migration in the ground tend to be slow, so more emphasis needs to be placed on systematic measurement of the distribution of radioactivity in close proximity to the burial trenches. This should permit considerably more reliable projections of future behavior of the facility than more remote measurements. .

\subsection{Space Utilization}

Current methods used in the management of low-level, solid radioactive wastes result in the use of large areas of land per unit of waste. Significant improvements in the burial space utilization factor is possible but to date it has not been cost-effective. However, capacity for expansion is limited at several sites.

ERDA Manual Chapter 0511 mandates the application of volume reduction techniques to solid radioactive wastes at contractor sites whenever practical. Compaction and incineration could be used to reduce waste volume at many sites (Ge77, Bu72, Ga79). Standardized packaging and better placement of packages in trenches could also improve the volume utilization factor (Mu176, Bu72, Ga79).

At arid sites, such as Beatty, Richland, and Hanford, the depth of the trenches could be increased appreciably without coming undesirably close to 
the water table (Mul76, Ga79). This could greatly increase the capacity of burial per unit land area. However, at the Hanford Reservation the near surface earth material is known to have a shallow angle of repose which could limit the cost-effectiveness of deeper trenches at that site (Ge77). Increased width of trenches and closer attention to trench configuration could also provide improvements in land utilization (Mu176, Ga79).

A recent study has noted that improvements underway at INEL will at least double recent utilization (Ga79). Estimates for space requirements should include provisions for a buffer zone between the trenches and the site boundary.

\subsubsection{Evaluation of Volume Reduction Techniques}

The objective of this technical issue is to evaluate the usefulness of waste volume reduction as an aid in reducing the demand for land at shallow land burial sites. Compaction could substantially reduce waste volume at a number of sites (Ga79, Ge77, Bu72). Volume reduction of compactible waste has been carried out at INEL for several years, with post-compaction volume roughly an order of magnitude less than the original volume.

Incineration could also reduce waste volume but may lead to atmospheric releases of radionuclides. Other means for volume reduction, including, but not limited to, segregation and separate handling of non-radioactive wastes, should be evaluated.

The advantages of volume reduction should be evaluated for each site. This evaluation should consider costs, space, time, potential hazards, etc. versus future availability of land for expansion of land-burial facilities. The increased handling required in volume reduction will increase radiation exposures to operators and these potential hazards must be considered. The 
cost-effectiveness of volume reduction may differ from site to site depending on the relative amounts of compactible waste.

\subsubsection{Evaluation of Modifications in Space Utilization}

The objective of this technical issue is to evaluate techniques to improve the use of land area for shallow land burial. Standardized packaging and better placement of packages in trenches would decrease the void volume in trenches and improve space use (Ga79, Mul76, Bu72). Standardized packaging would also facilitate improvements in shielding and package handiling for better safety to operators during waste recelpt and emplacement at the burial ground, but might require additional handling at the waste source, especially if bulky items must be disassembled to fit into standard packages.

Modifications in trench orientation and geometry may be appropriate. Trenches at a number of arid sites could be deepened to increase available storage volume (Ga79, Mul76). Increasing the width of trenches and placing them closer together could also improve space utilization, but care must be taken not to destroy the integrity of the trench walls. Provisions must be allowed for a buffer zone between the trenches and the site boundary.

\subsection{Management Pxactices}

At sites where there has been no detectable migration of radionuclides, the problems that have occurred have resulted largely from lapses in good management practice. There is a need tu establish codes of practice to facilitate quality control for management practices at operating facilities. 
The objective of this technical issue is to promote the development of guidelines to facilitate implementation of good management practice for all aspects of facility operation (e.g. waste handling, emplacement, records, monitoring and site closure).

Interim criteria for burial ground operations have been prepared by DOE with assistance from the Shallow Land Burial Steering Committee. A final set of criteria is scheduled for issuance from the Idaho facility in fiscal year 1980 .

Rockwell-Hanford Operations maintains a written set of plans for waste storage and disposal (Mc78). They have also formulated a set of preliminary criteria for shallow land disposal (Sho79). Each facility should be encouraged to develop codes of practice for all steps of their operations based on generic performance standards for shallow land burial. The codes of practice should'contain written operational procedures to assure implementation of good management practices for selection, operation, and decommissioning of shallow land burial facilities. Working group meetings should be convened so that operators can share their experiences with respect to the success or shortcomings of specific management practices. These working groups could also develop generic codes of practice for shallow land burial.

The operational procedures of the various sites should be reviewed by a competent engineering firm with a view to developing a general code of good practice for shallow land burial The draft report could then serve as a working document for further refinement by a group of operators. After the document is finished it should be subject to periodic review.

The codes of practice developed in this effort, supplemented by performance standards and measures of performance, would be useful for 
groups wishing to make independent evaluations of the performance of burial ground operations. 


\subsection{SUMMARY}

The preceding chapters have discussed the technical problems and issues associated with the operation of shallow land burial facilities for low-level radioactive waste. Most of the technical issues are being addressed by the major DOE contractors in either the research and development programs or in the operational development and demonstration programs. However, current programs are not resolving the technical issues in a manner that provides optimum technology transfer. The programs tend to be highly site specific or provide only general information. While site specific studies are needed; attention should be given to evaluating and compiling the results of these studies for producing information applicable at other sites, thus implementing overall shallow land burial policy.

The technical issues fall into two broad categories. Some issues will be amenable to resolution after further research and development. Other issues can be resolved on the basis of current information. A major need in shallow land burial of low-level radioactive wastes is a formal policy consisting of a written set of goals, objectives, criteria, performance standards, measures of performance, and codes of practice. EPA, NRC, and DOE all have programs underway for the formulation of goals, objectives, and criteria for waste management in general and shallow land burial in particular. Development of the policy will require a great deal of interaction between the various responsible institutions. As the policy is further developed it should provide an excellent basis for improved direction of future technical research and development programs. Specific items deserving additional emphasis in research and development programs include: 
1. Water Management

- Field testing and engineering evaluation of techniques for control of infiltration and erosion.

- Development of a rationale for arriving at a balance between control of infiltration and erosion.

2. Radionuclide Migration

- Vajor phase migration and 1nteractions in the ytouina:

- Measurement and compilation of site-specific geohydrologic parameters.

- Migration of radionuclides through cracks and fissures.

- Effect of biological activity on radionuclide migration.

- Evaluātión of long-term chemical changes in the ground.

- Site-specific measurement of radionuclide migration.

3. Performance Evaluation

- Development of site-specific models of radionuclide migration to serve as a basis for design of monitoring programs.

- Development of criteria, performance standards, and measures of performance. 
- Improved monitoring inside the perimeter of the burial ground

4. Waste Records

- Standardization of records.

- Verification of waste receipts.

- Development and appreciation of techniques to construct inventories from past operations.

5. Predictive Capability

- Systematic evaluation of all significant mechanisms.and pathways of radinuclide release and migration.

- Development of models for vapor phase transport.

- Verification of models.

6. Space Utilization

- Evaluation of the feasibility of increasing trench depth.

- Evaluation of improved trench orientation.

- Evaluation of the need for waste volume reduction.

7. Management Practices

- Technical evaluation of policy options. 
THIS PAGE

\section{WAS INTENTIONALLY \\ LEFT BLANK}


APPENDIX

Site Summaries 


\section{Barnwell, South Carolina}

\subsection{Site Characteristics}

1.1 Location (SINB74, Mu176)

The Barnwell Radioactive Waste Disposal site is located in the southwestern part of south Carolina, adjacent to, and on the eastern border of AEC's Savannah River Plant. It is situated on the edge of the small community of Snelling, south Carolina, which generally consists of a few residential homes, a trailer park, and several country stores. The nearest town is Barnwell, South Carolina, about five miles to the east.

\section{2 climate}

The climate of the site is described under Savannah River, South Carolina.

\subsection{Geology}

The geology of the cite ie decaribed under Savannah Piver, South Carolina.

\subsection{Hydrology (SINB74, Su79)}

There are no surface streams in the burial site area. The nearest surface stream, Lower Three Runs Creek, is about $1.7 \mathrm{~km}$ away. Surface water runoff occurs only rarely, and then only after unusually heavyt rainfall, because of previous sand deposits which cover the surface of the burial area and the gentle slope of the topography. Lower Three Runs creek drains the major portion of the site and empties into the Savannah River about $43 \mathrm{~km}$ downstream. There are no known users of the water of Lower Three Runs, and there is no use of the Savannah River water for a distance of approximately $145 \mathrm{~km}$ downstream from the Savannah River Plant. The 
major portion of the stream-flow in the local creeks represents water that has entered the stream channels after moving through the soil.

Other general observations and regional subsurface geohydrology are described under Savannah River, South Carolina.

1.5 Ecology

The ecology of the site is described under Savannah River, South Carolina.

\subsection{Licensing}

\subsection{Date and Authority of License (SINB74, Ma76)}

The original license granted to Chem-Nuclear Systems for operation of the Barnwell site was issued on November 6, 1969 by the South Carolina Board of Health, under authority of the state's Atomic Energy and Radiation Control Act of 1962. The original license allowed only above ground storage at the proposed burial site. A companion lease agreement was signed by Chem-Nuclear Systems and the South Carolina Budget and Control Board on January 21, 1970, leasing the burial site land and providing for a finaricial guarantee, in the form of an escrow account, to defray all safe muvenilint and wastc diopoeal costs shnuld Chem-Nuclear Systems cease its operations in the State.

On April 13, 1971, the license was amended to allow Chem-Nuclear Systems to bury radioactive waste. A new lease agreement between the operating company an the State was entered into on April 21, 1971, whereby the site was leased for ninety-nine years subject to compliance with the conditions of the State burial license.

\subsection{License Conditions (SINB74)}

The operating license has undergone six amendments, the sixth being 
issued on June 19, 1973, and lists 28 conditions. Some of the conditions pertaining to quantity, type and form of radionuclides include:

- A limit on unburied radioactive material at the site of

a. 5,000 Ci, excluding source and special nuclear materials.

b. 60,000 lbs of source material.

- The exclusion of transuranic wastes with the exception of Am-241.

- An independent evaluation of both hazards where wastes are toxic chemically and radioactively. If the chemical hazard is greater the waste may not be buried at the site.

Additional licensing conditions require the maintenance and routine submission of inventory records, the identification of burial locations of special nuclear material, and a limit of six months for above ground storage of received wastes.

The determination of increased concentrations of radioactivity in test. wells requires that the licensee perform further surveys to determine if the increase has resulted from burial operations. If so, the Division of Radiological Health is to be notified within 48 hours.

Additional licenses authorize the handling of spent ion-exchange resins containing radioactive waste and contaminated liquid waste at the burial site. The facility was also authorized by Lirnese No. 0128-04 the use of up to eight curies of $\mathrm{Na}-22$, up to $500 \mathrm{mCi}$ of $\mathrm{Sr}-90$, and up to 500 mCi of cs-137 for the process of converting metallic sodium to sodium hydroxide. A license was also obtained from the U.s. Atomic Energy Commission for the handling of $850 \mathrm{~g}$ of $\mathrm{U}-235$. 


\subsection{Operation}

\subsection{Dates of Operation (SINB74, Ma76)}

The facility was licensed for above ground storage of nuclear waste on November 6, 1969. Waste burial was authorized on April 13, 1971.

\subsection{Operations Techniques (SINB74, Mul76, Mac79, USERDA76a, Sh79)}

Two types of trench design have been used at the burial site. The initial trenches wére 60 meters long, 30 meters wide, and 4.5 meters deep. After the fourth excavation, trench dimensions were changed to 140 meters in length, 30 meters in width at the top, 10-12 meters width at the bottom, with trench depth sloped from 5 to 6.5 meters.

Trenches are constructed with a drainage field in the center of the trench bottom, 0.3 meters wide by 0.3 meters deep, filled with crushed rock for the length of the trench. The excavated trenches are backfilled with 1 meter of sand prior to waste emplacement. Upon completion of emplacement, trenches are backfilled such that a minimum of 0.6 meters of compacted clay lay between the waste and the ground surface. An additional 1.2 meters of earth is mounded on top of the clay cover. Topsoil is applied and a cover crop is planted. The trenches are inspected weekly and at subsequent three month intervals for settling. The trenches are regraded as required until the repacked soil becomes stabilized.

A marker monument is erected at the end of each completed trench with the following information inscribed:

(1) location and definition of trench boundary,

(2) total activity of radioactive material in curies, excluding source and special nuclear materials, total amount of source material in pounds, and total amount of special nuclear material in grams in the trench, 
(3) radionuclides with greatest hazard potential,

(4) date of completion of burial operations, and

(5) volume of waste in the trench.

The entire waste processing and burial area is enclosed by a high chain link security fence with barbed wire on top. The outside perimeter has all trees and shrubs cleared away to make a fire-break ring around the area. Access to the area is controlled and a daily record is kept of all personnel who enter.

3.3 Usaye (5INB74, Mac79; Le77)

The original tract of land deeded to the State of South Carolina and leased to Chem-Nuclear Systems for radioactive waste burial consisted of 3. 5 hectares. Another 7.5 hectares was later deeded to the State of South Carolina to provide additional burial space when all the trenches excavated in the original tract have been filled.

During the period from the beginning of burial operations in 1971 through the end of 1976, there had been $97,310 \mathrm{~m}^{3}$ solid waste buried at Barnwell containing approximately $4.8 \times 10^{b}$ curies of byproduct activity. $4.6 \times 10^{5} \mathrm{~g}$ of special nuclear material, and $1.6 \times 10^{5} \mathrm{kgg}$ of source material :

Approximately 68 of the available capacity has been used.

\footnotetext{
4.0 Monitoring (USERDA76a)

The operator monitors radioactivity concentrations semi-annually in ten onsite wells. Offsite water supplies are sampled annually. Offsite soil samples are taken quarterly; and offsite flora and fauna are sampled annually. A continuous air monitor is operated.
} 
5.0 Identification of Problem Areas

None identified. 


\subsection{Site Characteristics}

\subsection{Location (Mul76, USNRC77, USNRC76, USERDA76a)}

The Beatty commercial waste burial site is located on land owned by the State of Nevada about $18 \mathrm{~km}$ (11 miles) south of Beatty, Nevada and about $170 \mathrm{~km}$ (105 miles) northwest of Las Vegas. The land.is leased to Nuclear Englneering $10 .$, Inc., which operates the facility.

\subsection{Climate (USERDA76a, Ad78, Mac79)}

The climate is arid with a rainfall of about $100 \mathrm{~mm}$, which is greatly exceeded by the evapotranspiration potential. Thus, water infiltration is not a serious problem.

\subsection{Geology (USERDA76a, Mac79)}

The site is in the hasin and range dosert. Tho ourface formation consists of over 200 meters of alluvial sand and gravel underlain by folded metamorphic and sedimentary bedrock. The site is in a seismic hazard zone class 3.

1.4 Hydrology 9USERDA76a, Ad78, Mac79)

The nearest surface water is the ephemeral Amargosa River at a distance of $3 \mathrm{~km}$. The ground water table is at a depth of 80 to 90 meters in the alluvial sand and gravel, which has a variable permeability ranging from 0.02 to $0.1 \mathrm{~cm} / \mathrm{day}$. 


\subsection{Licensing}

2.1 Date and Authority of License (Mu176, USNRC77, Ma76, USNRC76, USERDA76a, Mac79)

The Beatty facility was the first commercial waste disposal facility to be licensed by the U.S. Atomic Energy Commission. The Nuclear Engineering Co., Inc. was originally licensed to operate the site in 1962. It is now licensed by the State of Nevada, an agreement state, to "receive, process, package, store and dispose of byproduct, source and special nuclear material" under 21 specified conditions under the authority of the State of Nevada Revised Statute 459 "Nuclear Affairs". In 1975 the State of Nevada placed a $10 \mathrm{nCi} / \mathrm{g}$ limit on the content of TRU. Reference in the license is made to Federal Regulations 10CFR20, 30, 40 and 70 , to Department of Transportation Regulations, and to Nevada Codes.

The site had an NRC license to bury special nuclear materials in quantities exceeding those licensable by the state, but this license has been suspended.

The State of Nevada has the commitment for assuring long-term care and maintenance of the site.

The State of Nevada suspended NECO's 1icense on March 8, 1976, and the NRC suspended its license on March 11, 1976. On May 25, 1976 the State of Nevada lifted its suspension.

\subsection{License Conditions (Mul76, USNRC77, Ma76, USNRC76, USERDA76a)}

The 8 page license from the State of Nevada permits the operator the basic authority to possess and bury wastes under 21 specified conditions. Solid wastes, with the exception of solids with induced activity and no removable contamination, must be packaged: Dewatered resins are accepted for burial and spent filter cartiridges in a disposable container 
are accepted for burial without solidification.

Liquids must be solidified before burial, but bulk liquid shipments are accepted at the Beatty site and they have the authority and capability for their solidification. Liquid scintillation vials are accepted for burial without solidification.

The only gaseous wastes accepted for burial are ${ }^{85} \mathrm{Kr}$ and ${ }^{3} \mathrm{H}$ not to exceed $1 \mathrm{Ci}$ per container and not to exceed a pressure of 1.5 atmospheres. Combinations of radioactive and chemical wastes are not accepted for burial.

The limits for possession of unburied material are 50,000 Ci of non-TRU byproduct material, 25,000 pounds of source material, $500 \mathrm{~g}^{235} \mathrm{U}$, $300 \mathrm{~g}{ }^{238} \mathrm{U}$, and $300 \mathrm{~g} \mathrm{Pu}$. Since 1975 transuranic material above $10 \mathrm{nCi} / \mathrm{g}$ has not been accepted for burial.

A daily log of waste received is required to be maintained by the site operator showing quantity, type, and origin with container dose rates and transport class specified. Periodic summary reports are required on waste receipts, including volume; activities, grams of special nuclear material, pounds of source material, curies of byproduct material, and form of waste handled during the reporting period.

Burial trench specifications are indicated. A separate, permanent concrete or metal marker indicating basic information on buried material is required to be placed at each end of filled trenches.

Determination of radioactivity levels in surface and ground water is required, and soil and vegetation sampling, on a quarterly or monthly basis, 1s specified.

Other license terms of an administrative nature include:

a. Designation of operators and radiation safety. or health 


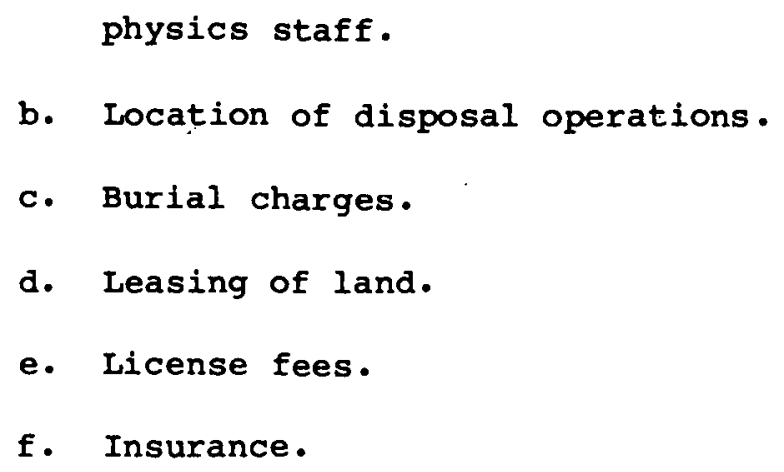

\subsection{Operation}

3. 1 Dates of Opcration (USNRG77, USERDA76a, USEPA76)

The site was 1 icense and opened for operation in 1962.

3.2 Operations Techniques (Mul76, USNRC77, USERDA76a, Ad78, Mac79)

Trenches are constructed with conventional earth moving equipment. Typical trenches are $260 \mathrm{~m}$ long, $12-15 \mathrm{~m}$ wide, and $8 \mathrm{~m}$ deep, although some trenches are up to $10.5 \mathrm{~m}$ deep. The bottoms of the trenches are well above the water table.

No special packaging is required for burial beyond those required for transportation by the Department of Transportation (DOT). Packaging methods currently used are not intended to provide containment after burial as the soil is considered to provide the essential containment. The bulk of the waste material is packaged in 210 liter mild steel drums approved by DOT. Very low activity wastes may be received in. wood or fiberboard boxes. Wastes are usually buried in the packages in which they are shipped except that material shipped in expensive, reusable casks may be repackaged prior to burial.

An attempt is made to place waste packages in trenches in an orderly manner. Waste packages are placed in a trench to within $1 \mathrm{~m}$ of the ground level. For burial of gas containers, the license usually specifies that 
the containers be buried in an upright position with minimum spacing $(10 \mathrm{ft})$ between containers. These wastes are placed in a steel can filled with a desiccant and sealed with tar or a similar material. The container is sealed in concrete in a clay, steel, or concrete pipe and placed in a trench. Gaseous wastes under pressures of more than 1.5 atm. are not accepted for burial.

The trenches are filled to $1 \mathrm{~m}$ below the original ground surface. When the trench is filled, a minimum of $2 \mathrm{~m}$ of earthfill with no compacting is used to cover the trench and it is mounded to $0.6 \mathrm{~m}$ above grade down the axis of the trench. There is no problem with infiltration of water and no further special provisions are made for water collection and containment or for compacting or sealing the trench cover.

Permanent markers are required within one year of the closing of a trench. The concrete posts used for markers include the following information:

\footnotetext{
- Trench number

- Date opened

- Date closed

- Lucation and definition of trenç boundary

- Total activity in curies; amount of source material in pounds; and total amount of special nuclear material in grams

- Radionuclides with the greatest harard potential.

- Volume of waste.
}

Written records of waste disposals are required to include package type, volume, weight, quantities of radionuclides, chemical and physical form of the waste, and the radiation exposure from the package.

3.3 Usage (Mul76, USNRC77, USDOE78a, USERDA76a, Ad78, Mac79, Le77) 
During the period from beginning of operations in 1962 through the end of 1976, there had been $53,000 \mathrm{~m}^{3}$ of solid waste buried at the Beatty facility containing approximately $1.3 \times 10^{5}$ curies of byproduct activity, $684,000 \mathrm{~g}$ of special nuclear materials, and $40,400 \mathrm{~kg}$ of source material. At the end of 1977, the volume buried was $61,000 \mathrm{~m}^{3}$ which contained $1.56 \mathrm{x}$ $10^{5}$ curies of byproduct activity.

The commercial capacity of the site is estimated to be about $7 \times 10^{5}$ $\mathrm{m}^{3}$. Approximately 25 hectares of the site remain available for future use.

\subsection{Monitoring (USNRC76, CGO76, USERDA76a)}

The operator monitors the concentration of radioactivity monthly in the water of 1 onsite well and in offsite wells, and semi-annually in offsite ground water. A continuous air monitor is operated onsite and assay for radioactivity is made quarterly in soil and vegetation samples collected offsite.

No migration of radioactivity has been detected, but vapor diffusion of tritium in the soil is possible.

\subsection{Identification of Problem Areas}

\subsection{Site}

None identified.

\subsection{Waste}

The opinion of the U.S. Geological Survey is that more information is needed for all sites with respect to the ion exchange capacity of the soil and water chemistry. (USNRC76, CG076)

Migration of radioactivity has not been detected, but tritium could be diffusing through the soil in a vapor phase. (USERDA76a) 


\subsection{Operation}

The depth of burial could be increased appreciably without coming unnecessarily close to the water table. This could greatly increase the capacity of burial per unit land area. (Mul76)

Future containers and transport shields should be designed to minimize the time required for offloading and handling and standardized to permit a mechanized handling system. (Mul76)

Disposal site operators rely on the package labels or shipping documents prepared by the waste producer to maintain records of the waste rather than performing assays of packages on receipt. Many records contain only general information on the form, composition, or isotopic content of the waste. Better information is required to enable the operators to optimize waste management operations. (Mu176)

In March, 1976; a cement mixer used at the burial ground to solidify low-level liquid radioactive waste was found to have been used in the town of Beatty to pour concrete slabs at a local saloon and other private properties. The state also found evidence that other violations had occurred over a period of several years involving removal of contaminated tools, equipment, and supplies from the Beatty site by NECO employees. The State suspended NECO's license on March 11, 1976. (USNRC77, Ma76)

A Federal/State investigation was conducted at Beatty and revealed that the contaminated equipment, tools, and material had been removed from the site to the town of Beatty by NECO employees. No evidence was found that any member of the public had received a significant radiation exposure and contaminated material was turned in by citizens and returned to the NECO site. (USNRC77, Ma76)

On May 25, 1976, the Nevada Department of Health and Welfare lifted 
the order suspending NECO's State license authorizing operation of the Beatty burial ground on the basis that the emergency conditions had abated and that there was no significant hazard to the public health and safety at and in the vicinity of the disposal site. (USNRC77, Ma76)

\subsection{Performance Evaluation}

Further information on rates of infiltration and the direction and rate of ground water movement is needed to predict the direction and rate of radionuclide migration. (USNRC76, CG076) 
Hanford Works, Richland, Washington

1.0 Site Characteristics

1.1 Location (NAS76, Ge77, Br77, Is 78)

The Hanford Reservation is located in southeastern Washington, about $50 \mathrm{kilometers} \mathrm{(} 30$ miles) east of Yakima and 5 kilometers ( 3 miles) north of Richland, in the Pasco Basin on the Columbia River Plateau. The Pasco Basin is an arid reqion in the rain shadow of the Cascade Mountain Range. The area is bounded on the north and east by the valley of the columbia River, on the north by the Saddle Mountains, on the west by Umtanum Ridge, Yakima Ridge and the Rattlesnake Hills, on the south by the Rattlesnake Hills and a series of anticlines which merge with the Horse Heaven Hills, and on the east by the Jackass Mountain Monocline.

1.2 Climate (NAS76, Ge77, MAC79, USERDA76b, Is78)

The Hanford climate is mild and dry with occasional periods of high winds. Summers are generally hot and dry and the winters are relatively mild. The average annual precipitation is $160 \mathrm{~mm}(6.3 \mathrm{in})$ with 428 occurring in. November, December, and January. A maximum annual precipitation of $460 \mathrm{~mm}$ (18 in) would be expected once in a thousand years. Lysimeter data collected since 1971 indicate that all incident precipitation is returned to the atmosphere by evaporation.

The average maximum temperatures in January and July are $2.6^{\circ}$ and $33.2^{\circ} \mathrm{C}$, respectively, and the average minimum temperatures for the same months are $-5.5^{\circ}$ and $16.1^{\circ} \mathrm{C}$. The average relative humidity ranges from 31.8 percent in July to 80.4 percent in December.

Mean monthly wind speeds range from about $8 \mathrm{~km}$ per hour in winter to $15 \mathrm{~km}$ per hour in summer; the wind speeds are lowest in mid-morning and 
highest in the late evening. The prevailing wind directions are from the north-northwest but the strongest winds are from the southwest. Gusts of $65 \mathrm{~km}$ per hour or greater are observed on the average of at least once in every month of the year, but with higher frequencies in winter. Tornadoes are infrequent--fourteen have been confirmed within $160 \mathrm{~km}(100 \mathrm{miles})$ of the Hanford Reservation since 1916. When they do occur they tend to be small and inflict little damage.

1.3 Geology (NAS76, Ge77, Br77, Mac79, USERDA76a, USERDA76b, Is78) The Pasco Rasin is underlain by three major geologic units. The bedrock is Yakima Basalt of the Columbia River Basalt Group, a dense hard basaltic lava. The Ringold Formation, consisting of a layer of up to 370 meters ( 1200 feet) thickness of semiconsolidated lake and stream sediments, lies directly over the bedrock and generally conforms with the surface of the bedrock. The uppermost formation is the Hanford Formation which consists of up to 60 meters (200 feet) of unconsolidated sands, silts, and gravels deposited in the area from glacial flood waters. Unconsolidated eolian silt may be considered a fourth major geologic unit. The burial grounds are located in the glaciofluvial deposits varying in texture from sandy gravel in the reactor areas to slightly silty to fine sand in the laboratory areas and silty sandy gravel in the chemical processing areas.

Faults mapped. in the columbia Plateau appear to be directly related to folds within the basalt; the folds being the primary response to tectonic deformation and faulting and secondary response. Faults in the basin are generally of limited length (less than $20 \mathrm{~km}$ ), of minor offset (less than $60 \mathrm{~m})$, and do not appear to be from recent fault activity.

1.4 Hydrology (NAS76, GE77, BR77, MAC79, USERDA76a, USERDA76b, Ad78, Is 78, Ro78) 
The Columbia River flows through the Hanford Reservation, and the Yakima River borders part of the Reservation's southern boundary. In addition, there are two ephemeral streams on the reservation, one natural pond, and a number of man-made ditches and ponds formed by the disposal of low-level liquid radioactive waste and cooling water. The Columbia River lies about $10 \mathrm{~km}$ from the waste disposal areas. The normal annual mean flow rate of the Columbia River at McNary Dam, after the entry of the Yakima, Snake, and Walla Walla River, is $5320 \mathrm{~m}^{3} / \mathrm{sec}$.

Generally, the groundwater on the Hanford Reservation exists under unconfined or water table conditions, through some locally confined zones exist. The depth of the water table depends on the topography and ranges from 0.3 meters $(1 \mathrm{ft})$ to more than 90 meters $(300 \mathrm{ft})$ below the land surface. The discharge of large volumes of cooling water and liquid wastes at Hanford has produced two large groundwater mounds. The mounds have affected the natural groundwater regime, locally reversing the flow of groundwater and increasing the hydraulic gradient and flow rate to the Columbia River. Beneath the 200-West Burial Grounds the depth to the water table ranges from $60-70 \mathrm{~m}(195-230 \mathrm{ft})$. In the 100 and 300 areas, which are relatively close to. the columbia River, the depth to water varies from about 5 to $2 \overline{5}$ meters $(15-80 \mathrm{ft})$. The thickness of the saturated zone of the unconfined aquifer ranges from 15 to 75 meters $(50$ to $250 \mathrm{ft})$. The horizontal hydraulic conductivity of the Ringold formation on the reservation ranges from 0 to 60 meters per day (200 ft/day). The range for the glaciofluviatile deposits is 360 to $4300 \mathrm{~m} /$ day $(1200$ to $14,000 \mathrm{ft} /$ day $)$.

The natural recharge of groundwater due to precipitation over the low land of the reservation is not measurable, as the annual evaporation potential exceeds the total precipitation. Natural precipitation migrates 
in deep soils at a rate of less than $1.3 \mathrm{~cm}(0.5 \mathrm{in})$ per year at one location where it has been. measured. However, infiltration rates of 16 to $22 \mathrm{~mm}$ of water per hour have been measured. Under these conditions, surface runoff is negligibly small except during periods of rapid snownelt over frozen ground. The major source of natural recharge arises from precipitation on the uplands to the south and west of the Reservation. Groundwater flow is to the southeast toward the Columbia River.

Several wells on the Reservation and twenty wells at the City of Rlchland withdraw water from the water table ayuifer.

\subsection{Ecology (Ge77, Br77, Is 78)}

Southeastern Washington has a sparse covering of natural vegetation and is primarily suited for grazing. During the past few years large areas near the reservation have been irrigated with water from the Yakima and Columbia Rivers.

The Hanford Reservation is a shrub-steppe grassland. The most extensive vegetation association is sagebrush/cheatgrass/bluegrass. Spring hopsage, rabbitbrush, balsam root, and tumble mustard are found in association with sagebrush. Cheatgrass dominates the fields abandoned 30 years ago. Tumbleweed is not as competitive as cheatgrass but is successful where cheatgrass is suppressed. In the absence of livestock grazing both are effective in limiting wind and water erosion of the soil.

There are small willow communities along the banks of the Columbia river. The willows and associated deciduous trees, shrubs, and herbaceous plants provide food and nest sites for song and game birds and forage and cover for mule deer. Bitterbrush is an important forage plant for mule deer in fall and winter.

Mule deer and wapiti are the only big game mammals found on the 
reservation. The wapiti have become established only recently. Small manmals include cottontail rabbits, raccoons, beavers, muskrats, mink, weasels, coyotes, bobcats, badgers, jackrabbits, porcupines, pocket mice, deer mice, ground squirrels, and pocket gophers: The pocket mice, deer mice, and ground squirrels are abundant, and are the most likely to invade the burial grounds. The jackrabbit is an important food item for coyotes and raptorial birds.

Raptorial birds (hawks, falcons, owls) nest on the Hanford Reservation. The osprey is an occasional visitor along the columbia River and the golden eagle and the bald eagle are winter visitors. The chukar partridge is the most important upland game bird on the reservation. Other game birds include pheasants, quail, and sage grouse. During the spring months migratory mourning doves nest throughout the reservation.

The Columbia River provides nesting for migrating flocks of ducks and Canada geese.

Compared to desert areas of the. southwestern U.S., the herpctofauna (snakes and lizards) of the area is sparse.

Insects, especialy mealybugs which occur in association with bluebunch wheatgrass, are abundant throughout the major plant communities on the reservation.

\subsection{Licensing}

The Hanford Works waste facility is operated for the U.S. Department of Energy by Rockwell Hanford Operations and is not a licensed facility. The operations are regulated by the U.S. Energy Research and Development Administration Manual Chapters. 


\subsection{Operation}

\subsection{Dates of Operation (NAS76, Ge77, USERDA76b)}

Solid radioactive wastes have been disposed of by shallow land burial at the Hanford Reservation since the beginning of operations in 1944 . Historically, nearly all of the wastes were buried in the area in which they were generated, but in 1968 increasing amounts of waste were transported to the 200 Areas and since 1973 essentially all solid radioactive waste generated at Hanford has been stored or buried in the 200 Areas .

\subsection{Operations Techniques (NAS76, Ge77, Br77, Mac79, USERDA76A, USERDA76b)}

Hanford soil consists largely of gravel and sand, and sloughs off to an angle of about $45^{\circ}$ during excavation. Thus, burial trenches are much wider at the top than at the bottom. Typical trenches are 1.5-5 meters wide at the bottom of the trench, 4-8 meters deep, 14-20 meters wide at the ground surface, and variable in length.

Wastes are transported to the burial trenches in a variety of types of packages, including sealed cardboard boxes, 55-gallon drums, and specially fabricated whnd, metal, or reinforced concrete containers. Large pieces of contaminated equipment are packaged into large concrete boxes for transport by rail car to the burial site where they are remotely lowered on a ramp into the trench. In other cases, equipment may be buried directly without packaging.

Wastes are not compacted prior to disposal because of the high costs of providing an effective system. The trenches are filled from the end. Wastes to be buried are segregated according to categories and combustible wastes are not buried with noncombustibles. 
All buried radioactive waste is covered daily to the same level as the surrounding surface with at least 2.5 meters of backfill or enough to reduce the radiation exposure rate at the surface to less than $1 \mathrm{mR}$ per hour. In the 100 Areas the waste is 4 to 26 meters and in the 300-600 Areas 4 to 88 meters above the water table. In the 200 Areas the depth to the water table is 60 to 70 meters. No provisions are made for the collection or containment of water in the burial trenches.

Physical surveys are made monthly or semiannually to check undesirable weed growth, trench slumping, soil erosion, boundary markings and fencing, damage caused by wildlife, and other undesirable changes. The integrity of the burial grounds is preserved by filling slumps, maintaining surface contours, removing deep rooted plants, and other maintenance as required. Radiation surveys are made to assure that the radiation level is kept below $1 \mathrm{mR}$ per hour three feet above ground level, and to monitor for spread of contamination and radionuclide uptake in plants.

All active storage and burial sites in the 200 Areas have lightcd perimeter fences with manned gates; security clearance is required for admittance and the areas are routinely patrolled. All burial grounds have semipermanent perimeter markers.

All wastes are monitored at their point of orlgin and packages must be free from external contamination. The dose rate at the surface of the package and an estimate of the radinactive inventory ic recorded. Reroris of waste receipts are compiled on a quarterly basis and retained in a fireproof repository. After a specified time the files are transmitted to long-term storage. However, there are no detailed records of solid wastes buried during the period 1944 to 1974 .

The fissile content of each container accepted for burial is recorded 
on the shipping papers. The amount of fissile material is limited to 175 grams per square foot of area in the burial area.

\subsection{Special Management Techniques (Ge77)}

Caissons are used to dispose of solid wastes with high exposure rates. Caissons consist of vertical corrugated metal cylinders of $122.4 \mathrm{~m}$ diameter with concrete slabs closing both ends. The inlet chute is $0.9 \mathrm{~m}$ ( $3 \mathrm{ft}$ ) in diameter and is offset to block radiation "shine". During filling the caisson is vented through a HEPA filtered exhaust with an attached air sampler. When the caisson is filled, or when the radiation level becomes too high, it is buried in place with the tops about $4.3 \mathrm{~m}(14 \mathrm{ft})$ below the ground.

3.4 Usage (Ge77, Mac79, Ga79)

Complete records on solid waste burial. were not kept during the early days of operations at Hanford. Some documents on waste disposal activities were issued during the 1950's and 1960's, but the information is incomplete. Currently, records are maintained of the land area used, the volume of waste, the curie quantities of specific radionuclides, and the coordinates of burial. Estimates have been made of the volumes and radisactivity of previously unrecorded wastes buried in the 100 and 200 Areas based on known and deduced waste generation and disposal information. Estimates of volume of waste buried range from 2 to $3 \times 10^{5} \mathrm{~m}^{3}$ and the area required from 7 to $12 \times 10^{6} \mathrm{~m}^{2}$. The inventory of radioactivity contains an estimated $8 \times 10^{5} \mathrm{Ci}$ of beta-gamma emitters, $365 \mathrm{~kg}$ of transuranics, and 6 $\times 10^{5} \mathrm{~kg}$ uranium.

In the period from 1969 through 1977, an annual average of $6400 \mathrm{~m}^{3}$ of solid low-level waste has been buried at Hanford requiring an average gross surface space of $1.8 \times 10^{4} \mathrm{~m}^{2}$ pex year. There is estimated to be more than 
1000 acres of area remaining on the Hanford Reservation suitable for shallow land burial.

4.0 Monitoring (NAS76, Ge77, Br77, USERDA76a, USERDA76b, Ad78, Is78)

Although environmental monitoring for the Hanford Reservation as a whole is quite extensive, there is no specific program for subsurface monitoring of dry waste burial grounds. The groundwater monitoring program has been designed primarily to monitor the effects on the water table aquifer from the ground disposal of liquid radioactive waste. However, three groundwater monitoring wells have been drilled in the vicinity of burial grounds and are checked occasionally for possible migration of radionuclides from dry wastes to groundwater. The potential contamination of groundwater attributable to the burial grounds is believed to be small compared to the liquid sources:

Ground surface contamination has occurred on several occasions due to collapse of buried wooden containers. Deep ront.en plants, such as tumbleweek, sagebrush, and rabbitbrush, accumulate and concentrate certain radionuclides and there is a limited potential for intrusion of animals into the buried wastes. Plants and animals are periodically collected frnm the burial grounds to determine if they have accumulated radionuclides from the ground.

Surveys are made semiannually of the ratiation exposure ratco above the ground surface.

\subsection{Identification of Problem Areas}

\section{1 Site}

The space utilization factor for solid waste burial on the Hanford 
Reservation is quite poor because the abundance of suitable land for disposal areas has not made it cost effective to implement measures for improvement. Compaction, improved packaging, improved emplacement, and increased width and depth of trenches could improve the space utilization factor (Ge77, Ga79). Combustibles comprise about 508 of the wastes generated at Hanford (Da74).

Radionuclide uptake by deep rooted plants has been observed and there is some potential for intrusion of animals into the waste trenches (USERDA76a, Ad78, Is78). This problem probably constitutes the greatest long-term threat of transporting radioactivity into the uncontrolled environment (Is78).

Measures should also be developed and evaluated for protection against adverse weather conditions. Wind erosion and reduction of ground cover can expose buried waste (Is78). This is controlled by surveillance and additional backfilling.

The lithology beneath the waste burial area is not completely described (USERDA76b).

\subsection{Waste}

Radionuclide migration from the waste trenches is small compared to that arising from the ground disposal of liquid wastes. The mechanism controlling water/radionuclide transport in unsaturated zones needs further investigation conditions (USERDA76b).

\subsection{Operation}

Trench caps sometimes fail because of the formation of voids as the waste packages deteriorate and compact (Is78). Combustible materials sometimes catch fire. The records of waste buried during the early years of operation are incomplete (NAS76, Ge77). 


\subsection{Performance Evaluation}

The environmental monitoring program conducted specifically for evaluating the performance of shallow land burial activities on the Hanford Reservation is limited, although there is an extensive program for the reservation as a whole (NAS76, GE77, USERDA76b). 
Idaho National Engineering Laboratory, Idaho Falls, Idaho

\subsection{Site Characterization}

1.1 Location (Ba79, Ken79)

The Idaho National Engineering Laboratory (INEL) is a government reservation located in a sparsely populated region of southeastern Idaho. The burial ground, or Radioactive Waste Management Complex (RWMC), comprises approximately 250 hectares (100 acres) of level ground in a shallow valley in the southeastern part of the INEL about 3.5 miles $(5.6 \mathrm{~km})$ north of the southern INEL boundary, about 54 miles $(87 \mathrm{~km})$ west of Idaho Falls, and about 22 miles $(35 \mathrm{~km})$ southeast of Arco.

\subsection{Climate (NAS76, USERDA77, Ba76, Mu64, Ba79)}

Idaho Falls has an arid climate. The average annual precipitation at the INEL is 8.5 inches. Precipitation is at a maximum during May and June, and falls to a minimum in July. Snowfall ranges from a low of about $360 \mathrm{~mm}$ (12 in) to a high of about $1150 \mathrm{~mm}$ (45 in) per year. The months of November through April, although snow occasionally falls during May, September, and octuler.

On the average, two or three thunderstorm days occur during each month from June through August. Strong wind gusts can occur in the immediate vicinity of thunderstorms. These gusts are usually quite localized and of short duration. Although small hail frequently accompanies the thunderstorms, damage from hail has not occurred at the INEL.

Five funnel clouds (vortex clouds which do not reach the ground) and two tornadoes (which caused no damage) have been documented in the 23 year period of observation at the INEL. 
During a 22 year period of record, the extremes of temperatures have ranged from a low of $42^{\circ} \mathrm{C}$ in January to $39^{\circ} \mathrm{C}$ in July. During winter the average maximum temperature is approximately $-3^{\circ} \mathrm{C}$ with an average minimum of approximately $-16^{\circ} \mathrm{C}$. In sumer the average maximum temperature is $30^{\circ} \mathrm{C}$ and the average minimum is about $10^{\circ} \mathrm{C}$.

Extensive evaporation data have not been collected at INEL. Based on evaporation information from Aberdeen and Kimberly in southeastern Idaho, a $910 \mathrm{~mm}$ (36 in) average annual evaporation rate has been suggested. However, according to Mundorff and others, evapotranspiration by sparse vegetation of the Snake River Plain was estimated at 150 to $230 \mathrm{~mm}$ per year. The lack of vegetation within the burial ground would probably result in lower evapotranspiration rates as compared to other parts of the plain. During the coldest months, evaporation is small and may be insignificant. Times when the most precipitation water is available for infiltration, late-winter to spring rains or snow, coincide with times of relatively low evapotranspiration rates.

\subsection{Geology (NAS76, Ba76)}

The INEL is located entirely on the Eastern Snake River Plain, with the mountains to the northwest providing the northern boundary of the pla1n. Except for small areas along the mountain fronts and two volcanic cone-line buttes, the entire INEL area is underlain by a succession of Pliocene, Pleistocene, and geologically reçent basaltic lava flows. These form layers of hard rocks of thickness varying from 3 to 30 meters (10 to 100 feet). Unconsolidated material, cinders, and breccia are interbedded with the basalt. The depth of these layered deposits is inferred to range from less than 300 meters $(1,000 \mathrm{ft})$ to more than 1,500 meters $(5,000 \mathrm{ft})$. Surface soils and regolith along the streams are made up of alluvial 
sands and gravel of varying thickness. The surface soils over the remainder of the INEL are formed by eolian and loessial deposits of varying thickness. Sandy soils derived from wind-worked beach and bar deposits formed in old playa lakes or ponds are common in the northern part of the site. In many places basalt rock is not covered. Alluvial fans occur along the mountain fronts.

INEL lies within a young volcanic-tectonic feature, the Arco Rift Zone. The recurrence interval of volcanic eruptions, faulting, and possibly earthquakes in the Arco Rift Zone is estimated at approximately $10,000 \mathrm{yr}$.

\subsection{Hydrology (NAS76, USERDA77, Ba76, Ba79)}

The burial ground is within $3.2 \mathrm{~km}$ ( 2 miles) of the Big lost River and the surface is approximately $12 \mathrm{~m}(40 \mathrm{ft})$ lower than the present river channel. The Big Lost River flows southwestward down the Big Lost River valley past Arco onto the Snake River Plain, turns northward through the INEL and terminates in ponding areas. The river continually loses water on the plain by infiltration through the channel bottom and sides.

The maximum discharge recorded to date of the Big Lost River ocurred October through September in water year $1965(397,000$ acre-feet/yr at a point below Mackay) and the average for $57 \mathrm{yr}$ of record is 210,800 acre-feet/yr. At present the INEL diversion system can control a 55 yr flood.

All flow of the Big Lost River that enters onto the Snake River Plain is recharged to the subsurface, except for evaporation losses. Recharge effects from the Big Lost River are very pronounced in the Snake River Plain aquifer and in perched water beneath the river.

Because of its topographic setting, the burial ground has been flooded 
at least twice in recent years (1962 and 1969) by local runoff from rapid spring thaws. Since 1969, the protective dike system has been enlarged. Heavy rainfall and melting snow within the burial ground have also introduced water into the trenches and pits, especially where the soil cover has slumped and cracked.

The INEL is underlain by the Snake River Plain aquifer which is about $320 \mathrm{~km}$ long by 50 to $100 \mathrm{~km}$ wide $(200 \mathrm{mi}$ by 30 to $60 \mathrm{mi})$. The aquifer is composed of a series of this basalt flows, generally 3 to 23 meters ( 10 to $75 \mathrm{ft}$ ) thick, with interbedded layers of fluvial, lacustrine, wind-blown and pyroclastic sediments. Most of the permeability occurs along the upper and lower contacts of successive basaltic flows that have large and irregular fractures, fissures, and other voids. Seismic and deep resistivity data indicate that the aquifer may be about $1,500 \mathrm{~m}(5,000 \mathrm{ft})$ thick in the INEL region.

Groundwater flows generally southwestward through the aquifer from the north and northeastern recharge areas to the south and southwestern discharge areas. However, beneath the RWMC the flow is to the northeast, counter to the regional direction of flow. Depth to the regional water table at the INEL varies from about $60 \mathrm{~m}(200 \mathrm{ft})$ in the northeast corner to $275 \mathrm{~m}(900 \mathrm{ft})$ in the southeast corner. The average hydraulic gradient is about $1 \mathrm{~m}$ per $\mathrm{km}$ ( $5 \mathrm{ft}$ per mile) to the southwest.

Average flow rates in the aquifer are difficult to assess. Tracer studies at the INEL indicate natural flow rates in the range of 1.5 to 6 meters per day with an average near 3 meters per day. However, these local measurements are not necessarily representative of velocities throughout the aquifer.

The only significant natural recharge to the aquifer in the INEL 
vicinity is from the Big Lost River. A small amount of recharge occurs from infiltration of precipitation directly on the site, and, during some years of high runoff, Birch Creek water flows onto the station and seeps underground. The Big Lost River drains into a closed basin terminating at the northern end of the station. When the Big Lost River flows onto the site, it infiltrates the channel bottom and percolates downward toward the aquifer. Layers of fine-grained sediments with low permeability tend to retard the downward percolation forming perched groundwater beneath the river.

Unsaturated flow is probably the predominant form of subsurface moisture movement between the land surface and the Snake River Plain aquifer. On several occasions, water has infiltrated the burial ground and percolated through the surface sediment layer into the basalts.

A perched water table exists beneath the burial ground and indicates that at least one areally extensive zone near the 200-foot $(61 \mathrm{~m})$ depth exceeds field capacity. Most of the water that has percolated through the waste will eventually reach the water table, either by saturated flow or by unsaturated flow, unless all future surficial sources of water are permanently eliminated.

\subsection{Ecology (USERDA77)}

The vegetation of the INEL is limited by the type of soil, meager rainfall, and extended drought periods to mainly sagebrush, perennial herbs and a variety of grasses. The INEL has only a few trees, located principally along the Big Lost River.

The vegetation of the INEL supports a variety of wildlife consisting mainly of small manmals, birds, reptiles, and a few large mammals. The small mammals include chipmunks, ground squirrels, several species of mice, 
kangaroo mice, kangaroo rats, and jackrabbits. The pronghorn antelope inhabits the INEL during the entire year; however, many of the antelope are migratory and winter south of the INEL and summer to the north of it. Antelope occasionally fawn on the station in the spring as they move northward into the Birch creek valley. Coyotes and bobcats are seen frequently. Sage grouse and pheasants are the only resident game birds on the INEL; however, hunting is not permitted. In addition to raptors and other indigenous and introduced species of birds, some migrant species pass through the areas. These include doves, hawks, ducks, geese, and golden and bald eagles. The only endangered species occasionally frequenting the station is the peregrine falcon. The reptiles consist mainly of lizards and a few snakes. Domestic sheep and cattle are allowed to graze on the perimeter areas of the station in the early spring and fall. Large mammals are excluded from the immediate facility areas by security fences.

\subsection{Licensing}

The waste disposal facilities at the Idaho National Engineering Laboratory are operated by EG\&G Idaho, Inc., a prime contractor for the U.S. Department of Energy, and is not a licensed facility. The operations are regulated by the U.S. Energy Research and Development Adminisstration Manual Chapters.

\subsection{Operation}

\subsection{Dates of Operation (USERDA77, DM78)}

Burial of low-level radioactive waste at the burial ground was initiated on July 8, 1952. The wastes included contaminated laboratory implements, activation products, and wastes contaminated with fission 
products. Beginning in 1954 transuranic wastes from the Rocky Flats Plant in Colorado were also buried and stored in the Radioactive Waste Management Complex.

\subsection{Operation Techniques (NAS76, USERDA77, Ba76, DM78, We79)}

The trenches and pits are excavated to depths of 1.5 to 7.5 meters ( 5 to $25 \mathrm{ft}$ ) in unconsolidated sediments of fluvial, lacustrine and eolian origin. The pits range from 15 to 90 meters in width and 7.5 to 330 meters in length. The trenches are generally 1.2 to 7.5 meters wide, 100 to 550 meters long, and are spaced about 5 meters apart. The pits are generally 1.5 to 4.5 meters deep and the trenches 1.5 to 7.5 meters deep.

In some cases, the older pits and trenches were excavated down to the basalt bedrock or only a thin layer of soil was left to separate the wastes from the bedrock. Since 1970 two to three feet of soil has been left in place or backfilled to take advantage of the relatively low permeability of the soil and its ability to retard potential migration of radionuclides out of the trenches. Solid wastes are compacted into bales and placed in fiberboard boxes or metal drums with plastic liners; stacked in pits and trenches and covered with soil. Transuranic wastes are packaged in fiherglass reinforced, polyester-coated boxes of 7.4 cubic foot steel drums lined with polyethylene. Originally transuranic wastes were stacked in trenches and pits and covered with at least 0.6 meters of soil. More recently a separate storage area, the Idaho Transuranic Storage Area (ITSA) has been set aside at the east end of the solid waste burial ground. In this storage area the wastes are stacked above ground on asphalt and covered with layers of plastic and soil.

Solid radioactive waste enters the SDA in special shielded cask inserts, steel drums, wooden boxes, compacted bales, fiber barrels and 
special containers.

The shipper of radioactive wastes provides information for each shipment on waste volume, nuclide content, and activity. The dispositions of the wastes (including storage/disposal sites) are recorded on the forms and the information is compiled monthly into the INEL computerized radioactive waste reporting system.

\subsection{Special Management Techniques (Ken79)}

Non-routine waste, which consists generally of reactor canal refuse and spent ion exchange resins, emits radiation at levels greater than 500 $\mathrm{mR} / \mathrm{hr}$. These wastes are transported to the RWMC in shielded containers and handled remotely. Metal trench liners are used to provide shielding and to maximize use of trench space. A $38 \mathrm{~cm}$ concrete cover 1 s placed over the liner for shielding when the trench is not being filled. After the trench is filled the liner is extracted and the trench is covered with a minimum of $0.9 \mathrm{~m}$ of earth.

\subsection{Usage (Ba76, Os69, USAEC73a, USAEC73b, USAEC74, Fo79)}

The fenced burial ground is $9 \% 5$ meters long from east to west, and 520 meters wide along its east boundary. By July, 1975, approximately $14 \times 10^{4}$ $\mathrm{m}^{3}$ of solid waste had been disposed.

About six million curies of activity were disposed at the burial ground from 1952 through 1973. A total of about 15,000 g (51,000 Ci) of americium 241 (half-life $433 \mathrm{yr}$ ) has been disposed from 1954 through 1970. A total of about $366,000 \mathrm{~g}$ of plutonium has been buried. The amount of cobalt-60 (half-life 5.3 yrs) disposed from 1952 through 1970 is estimated to be more than $6000,000 \mathrm{Ci}$. Strontium-90 (half-life 28.9 yrs) has been disposed in unknown quantities through $1970,16.8 \mathrm{Ci}$ of strontium-90 was disposed in $1971,21.0 \mathrm{Ci}$ in 1972, and $187 \mathrm{Ci}$ in 1973. Little information 
is available about the disposal of cesium-137 (half-life $30.2 \mathrm{yrs}$ ) in the early years of the burial ground; $400 \mathrm{Ci}$ of cesium-137 disposed in 1971 , $270 \mathrm{Ci}$ in 1972 and $895 \mathrm{Ci}$ in 1972.

About 28 hectares (68 acres) has already been used for burial and another 4 hectares ( 10 acres) contains bedrock at essentially ground level. There are approximately 4 hectares (10 acres) of usable ground remaining for shallow land burial. If a trench utilization factor of 608 is attained, there is sufficient space remaining for about 12 years of operat.ion.

4.0 Monitoring (NAS76, USERDA77, DM78, Su79, We79)

An environmental monitoring program was established in the early 1950 s to characterize the routine, programmatic, and accidental releases from INEL nuclear testing. Background levels of natural and fallout radioactivity in surface soil were determined from soil samples collected from four distant and nine boundary locations during 1971, 1973, and 1974. A number of 5 to $10 \mathrm{~cm}$ depth samples were also collected to determine the relative distribution of radioactivity in two depth increments. A continuous air sampling program is maintained at nine onsite and ten offsite locations. Natural dustfall rates are measured routinely.

Four wells for routine water sampling, approximately 210 meters $(700$ $\mathrm{ft}$ ) deep, are located outside the burial grounds. One 76 meter (250 ft) hole is located within the burial grounds for monitoring. Twenty-seven additional shallow holes within the burial grounds are available to monitor the water and soil for migration of contamination in the subsoil.

Sampling of animals (primarily jackrabbits and antelope) and plants (mainly sagebrush) is conducted on an intermittent basis for monitoring 
uptake of radionuclides. The animals represent a sensitive indication of the levels of radionuclides from fallout of INEL effluents on vegetation. Gamma scans are performed on samples of antelope lung tissue, muscle tissue, liver tissue, and rumen to determine uptake of radionuclides. Thyroid and bone samples are analyzed for iodine-131 and strontium-90, respectively.

\subsection{Identification of Problem Areas}

\section{b. 1 Site}

The trenches have been vulnerable to infiltration and flooding of the burial grounds has occurred. (Ba79)

\subsection{Waste}

As a result of a fire at the Rocky Flats Plant in 1969 and resultant cleanup operations, a large volume of solid waste which was contaminated with plutonium and could not be economically decontaminated was brought to INEL. Publicity stemming from the fire caused questions to be raised by Idaho officials regarding the safety of burying the Rocky flats waste at Idaho. The concerns centered on the relatively long half-life of plutonium-239 and its toxicity. The implementation of 1970 Bureau of Radiological Health (U.S. Public Health Service) storage and monitoring recommendations did not fully satisfy the concern of Idaho officials as to the long-term safety of the aquifer underlying the INEL. Subsequent 1970 assurances by then AEC Chairman Glenn seaborg that the Pu-contaminated wastes from the Rocky flats plant would be exhumed and redeposited in a salt mine repository at Lyons, Kansas, became inadequate when the Lyons project was abandoned in 1972. (USERDA77)

In addition to the availability of a permanent disposal repository, 
other problems include the authorization, funding, and safety of waste exhumation. Particular concern has been expressed over the possible criticality during retrieval of buried Rocky flats waste containing plutonium. Further studies are needed in techniques and evaluation of exhumation hazards. Continuing migration studies are needed as part of the assessment of the need for a waste retrieval program. (NAS76)

\subsection{Operation}

Estimates of projected burial space needs to 1985 vary widely, ranging from about 508 of what is available today to 908 . The amount of burial ground required will depend both on the volume of radwaste actually generated and also on the efficiency with which the burial capacity is used. Current improvements underway at INEL to increase the trench utilization factor, such as volume reduction of compactibles, standardized packaging and better placement of the radwaste in the trenches, will lead to at least a doubling of the recent past utilization ( 308 ) and possibly as much as a tripling to 80 or 908 . It is clear that improved burial site efficiency is important in maximizing burial site life. (TEC79) 
Los Alamos Scientific Laboratory, Los Alamos, New Mexico

\subsection{Site Characteristics}

\subsection{Location (NAS76, USGS75)}

The Los Alamos Scientific Laboratory (LASL) occupies a reservation of about $310 \mathrm{~km}^{2}\left(120 \mathrm{mi}^{2}\right)$ covering most of Los Alamos County, New Mexico, approximately $40 \mathrm{~km}(25 \mathrm{mi})$ northwest of Santa $\mathrm{Fe}$.

1.2 Climate (NAS76, USGS75, USERDA76a, MaC79)

LASL has a semi-arid continental mountain climate. The average annual precipitation is about $450 \mathrm{~mm}(17$ in) per year with about 30 to 508 occurring during local thunderstorms in July and August. The annual snowfall is about $1270 \mathrm{~mm}(50 \mathrm{in})$. Evaporation data are not available for Los Alamos, but the evaporation potential is estimated to exceed the rate of precipitation.

The average annual temperature is $9^{\circ} \mathrm{C}\left(48^{\circ} \mathrm{F}\right)$; the average in July is about $19^{\circ} \mathrm{C}\left(67^{\circ} \mathrm{F}\right)$ and in January $-3^{\circ} \mathrm{C}\left(27^{\circ} \mathrm{F}\right)$.

Tornadoes occur in New Mexico, but are rare at elevations about 2,100 $m$ and are not considered a hazard at the disposal site.

\subsection{Geology (NAS76, EGH77, USGS75, Mac79, USDOE78b)}

Most of the Laboratory installations are on the Pajarito Plateau at an altitude of between 2,100 and $2,400 \mathrm{~m}(7,000$ and $8,000 \mathrm{ft})$. The Mesita del Buey, which is centrally located, is the only area presently usen for disposal of solid radioactive waste. It is a long narrow mesa sloping gently from west to east and bounded on the north and south by steep-walled canyons cut 15 to $30 \mathrm{~m}$ ( 50 to $100 \mathrm{ft}$ ) below the surface of the mesa by intermittent streams.

The oldest exposed Tertiary rocks in the Los Alamos area consist of 
sand, silt, clay, and some interbedded gravel; a part of this unit is called the Tesuque Formation. This unit is overlain by the Puye Formation consisting of coarse clastics, silts, and minor amounts of basalt with a maximum known thickness of about 221 meters $(726 \mathrm{ft})$. The municipal watex supply for Los Alamos comes from wells in the Puye Conglomerate and the underlying Tesuque Formation. The Puye Formation is covered by the Chino Mesa Formation, consisting of basalt and interbedded sediments, and in the Bandelier Tuff, a 75 to $180 \mathrm{~m}$ (240 to $590 \mathrm{ft}$ ) thick sequence of volcanic tuff and pumice. The overlying Tshirege Member is a cliff-forming unit capping the Pajarito Plateau. All of the solid waste burial pits have been excavated in the Tshirege Member.

The area is classified as a Tectonic zone 2, but there is no geological evidence that strong earthquakes have occurred in the Los Alamos region within recent geologic history. The anticipated frequencies of earthquakes, meteorite impact, and tornadoes for the waste burial site are very low.

1.4 Hydrology (NAS76, USGS75, USERDA76a, Mac79, USERDA76b, USDOE78b)

The Los Alamos reservation drains into the Rio Grande $8 \mathrm{~km}$ away by small, ephemeral streams. The flow rate of the Rio Grande is $28 \mathrm{~m}^{3} / \mathrm{sec}$ (990 cfs) at Albuquerque.

The regional water table is at a depth of about 260 to 365 meters ( 850 to $1200 \mathrm{ft}$ ) and slopes to the east into the valley of the Rio Grande. The horizontal velocity of the groundwater is estimated to be $30 \mathrm{dm}(1 \mathrm{ft})$ per day.

Perched water bodies are formed in the alluvium in canyons south of the mesa by recharge from intermittent streams. The perched water bodies discharge as springs, indicating that they exert some control on the 
movement of water in the zone of aeration.

Soil moisture not retained in the perched water zones percolates downward until it reaches the zone of saturation, but the amount of recharge by this route is quite small. The major source of recharge is from precipitation on the mountains and in the deep canyons cut into the western part of the plateau.

The burial trenches and shafts are excavated in tuff. The depth to the water table in these areas ranges from about $275 \mathrm{~m}(900 \mathrm{ft})$ to $365 \mathrm{~m}$ $(1200 \mathrm{ft})$ although some perched water is present locally. It is about $1 \mathrm{~km}$ to small ephemeral streams draining the area. Recent measurements have shown that precipitation may penetrate to a depth of about 5 meters in the disposal area. Tritium moving from a solid waste storage shaft was found to move in vapor phase through open joints in the tuff and in and through the tuff matrix.

Jointing is prominent in the Tshirege and rnntrols the hydrology of the burial sites. The joints range from hairline fractures to fissures several Inches wide. Many are filled with sediment, caliche, or clay, but some open joints have been observed. Water which has passed through the soil profile moves in the vapor phase, primarily along horizontal hedring planes in the tuff but also through the open joints and through the matrix of the tuff.

\subsection{Ecology (Ha73, USDOE78b)}

Six major vegetation community types are found in Los Alamos county. These are juniper-grassland, pinon-juniper, ponderosa pine, mixed conifer, spruce-fir, and subalpine grassland. The low level waste burial grounds are located exclusively in tuff on mesa tops; large portions of the mesa tops are covered. with the pinon-juniper complex. At this elevation the 
vegetation is predominantly evergreen trees, but shrubs, grasses, and forbs occur in the center. About 350 individual plant species have been tentatively identified for the general LASL area. The composite and grass families occur with the highest frequency and comprise the highest percentage of the ground cover at all the elevational sites. Burial grounds are covered with annual and biennial forbs, including white clover. Species lists compiled from field observations and published data show 20 mammalian families and 8 families of cold-blooded animals although in some cases species occurrence has not been verified. Small mammals inhabiting the pinon-juniper community are the deer mouse, pinon mouse, Colorado chipmunk, woodrat and mountain cottontail. Larger mammals include the coyote, grayfox, bobcat and Rocky Mountain mule deer.

Reptiles in the LASL environs include small lizards and king, bull, garter, and rattlesnakes. Other reptilian and amphibian species are suspected, but not documented. The largest variety of vertebrate wildife are birds; 187 species from 44 families have been reported. Approximately 30 of the listed faunal representatives are game species legally hunted in New Mexico.

Twenty-two endangered species are listed for north Central New Mexico. Eight of these species have been documented in Los Alamos County.

\subsection{Licensing}

Los Alamos Scientific Laboratory is operated by the University of California, a prime contractor for the Ü.S. Department of Energy, and 1s not a licensed facility. The operations are regulated by the U.S. Energy Research and Development Administration Manual Chapters. 


\section{0 Operation}

\subsection{Dates of Operation (USGS75, USDOE78b)}

Solid radioactive waste has been buried at Los Alamos since the beginning of operations in 1943; a waste disposal section was organized in 1945 to be responsible for management of radioactive wastes. No records were kept routinely until the mid 1950 's and the existing records are highly variable in quality. Detailed records of radionuclide concentration and waste composition have been kept since 1959 with continuous upqrading of the quality of the records.

\subsection{Operations Techniques (NAS76, Ke78, Ad78, USERDA76a, Mac79,} USDOE78b)

Unlined trenches 120 to $180 \mathrm{~m}$ long, 8 to $30 \mathrm{~m}$ wide, and 8 to $11 \mathrm{~m}$ deep, are excavated in tuff. A layer of at least $15 \mathrm{~cm}$ of crushed, compacted tuff is placed in the bottom of each trench prior to filling with waste. The trenches are filled in layers with the final layer $1 \mathrm{~m}$ helnw the surface and are then backfilled with a minimum of $1.5 \mathrm{~m}$ of tuff mounded to 0.5 to $1 \mathrm{~m}$ abovie grade atter compaction with heavy earth moving equipment. Combustible materials are covered daily and other materials as frequently as necessary for contamination and fire cont.rni. The trenches are separazed bỹ at least $4.5 \mathrm{~m}$ at the surface. Groundwater at the burial sites lie 275 to $365 \mathrm{~m}$ below the surface.

Low-level solid waste is usually packaged in plastic bags and fiber containers which are only sufficient to provide contamination control prior to emplacement. Some low-activity waste packages are compacted and baled to give a volume reduction factor of $5: 1$ to $10: 1$ before burial. Large, bulky items contaminated to less than $10 \mathrm{nCi} / \mathrm{g}$ are simply buried as is. A volume reduction facility using cutting and crushing techniques to reduce bulky 
wastes such as contaminated equiment generated by decontamination sites are in the designing stage, thus markedly reducing the volume of transuranic waste requiring retrievable storage.

There are no special provisions for water collection or water management other than the compaction and mounding of trench covers and the use of concrete caps on the tops of the vertical shafts. All active disposal sites and all but two inactive sites are inside security areas; in addition, most are fenced, marked, or both, to prevent entry by unauthorized personnel.

Prior to the $1950^{\prime}$ s no detailed records were kept. Beginning in 1959, detailed records were kept of radionuclide concentrations and waste composition and the quality of records has improved steadily since that time.

\subsection{Special Management Techniques (NAS76)}

Fission product waste with high gamma exposure rates is shielded during transport and placed into shafts excavated in tuff; the shafts are up to $19 \mathrm{~m}(64 \mathrm{ft})$ deep and lined with concrete or asphalt. Tritium-contaminated material is encased in asphalt and placed in shafts and metal containers of contaminated oil are stacked in the shafts. Fluid cement is also piped into asphalt lined shafts and allowed to harden in place. After the shafts are filled with waste they are capped with concrete.

Dewatered sludge is sometimes mixed with cement or sent to the burial site as sludge in 210 liter (55 gal) drums and placed in "retrievable storage" trenches.

3.4 Usage (Ke78, USGS75, USERDA76a, USDOE78a, Ga79, USDOE78b) There is currently an estimated 160,000 curies of activity contained 
in 2.2 to $2.4 \times 10^{5} \mathrm{~m}^{3}$ of solid radioactive waste buried at LASL. Previous records of waste burial are incomplete and the estimates are based on volumes of the waste trenches used. The major radionuclide is tritium, which constitutes about 938 of the total radioactivity. About 15 of the 32 hectares authorized for land burial have been used. Another 8 hectares (20 acres) was to be in use in 1978. Based on the gross surface area utilization factor, however, only about 10 hectares of the remaining original space is usable, This wil.] suffire for ahnut 40 years at projected rates of use.

Currently the average rate of burial of solid waste is about 7,000 to $8,000 \mathrm{~m}^{3}$ per year which requires about 0.3 hectares of area.

Most of the tritium contaminated wastes have been emplaced in shafts. The major radionuclides in the waste trenches are ${ }^{90} \mathrm{Sr}(3300 \mathrm{Ci})$ and ${ }^{241} \mathrm{Am}$ $(2220 \mathrm{Ci})$.

\section{4:0 Monitoring (Jo78, EGH77, Ke78, USERDA76a, USDOE78b)}

Environmental monitoring has been conducted at LASL since the beginning of waste disposal operations. The monitoring program is designed primarily for the reservation as a whole and only a few stations are intended specifically' to'monitor the waste disposal area.

A $12 \mathrm{~m}(40 \mathrm{ft})$ steel tower and an adjoining instrument shelter are currently being erected in Area $G$ to measure and reçord meteorological. parameters. Occasional air samples are taken during waste disposal operations, but there is no routine monitoring program.

The United States Geological Survey (USGS) performed radionuclide migration studies and a significant amount of monitoring in the 1950 's and 1960's. Hydrological monitoring consists of shallow wells, deep wells, 
surface wells, and springs. Routine monitoring has not indicated any signficant migration of radionuclides from the waste burial grounds although studies at a liquid waste disposal site showed that some radionuclides had migrated at least 8.5 meters through fissures in the tuff.

As the result of an evaluation by the USGS and LASL, a soil moisture monitoring program has been initiated to describe changes in moisture content in fill material over buried waste and in tuff surrounding waste disposal shafts. Geophysical studies are also underway to define waste trench boundaries and field radiation surveys are being conducted with a LASL-developed portable phoswich detector.

There are no routine soil or vegetation monitoring programs specifically for the burial site area, but special studies are made, including tritium diffusion.

Solid wastes are assayed upon receipt by an electronic instrument called MEgAs (Multiple Energy Gamma Assay system) to determine the concentration of transuranics. The sensitivity of this instrument is well below the $10 \mathrm{nCi} / \mathrm{g}$ level to ensure the proper segregation of TRU wastes. More than 908 of the waste packages from the major LASL plutonium processing facility can be buried rather than being retrievably stored.

\subsection{Identification of Problem Areas}

\subsection{Site}

There is some evidence of sheet erosion on some trenches and concern that buried waste could be exposed by erosional processes. (NAS76, USGS78) Moisture has moved through joints in the tuff. Some of the joints are filled with montmorillonite, a clay which swells when moistened. It is 
conceivable that expansion of the montmorillonite when moistened could cause expansion of the joints. (USGS75)

There is some concern that there will not be enough space to accommodate future requirements for waste burial. At the present rate of use, the area currently authorized for land burial is projected to last for about 40 years. The high value of 1 and in the community and the relatively small size of the reservation limit the ability to locate additional space for commercial land burial. (NAS76, Ga79)

\subsection{Waste}

Honeybees from Mortandad Canyon were found to contain tritium in concentrations 230 times that of the levels in effluent water readily available to the hive (Ri74, USGS75). The source of tritium is undetermined, but it has been postulated that the bees may have collected pollen from white clover which is abundant in a solid-waste burial area.

Most of the waste buried at LASL is contaminated with plutonium. The most evident chronic release mechanism appears to be uptake by deep-rooted plants and subsequent dispersal. (EGH77)

There is some concern that dramatic climatic changes could occur at the site before the plutonium has decayed to innocuous levels and that the migration of the plutonium might be enhanced. (NAS76, USERDA76a)

\subsection{Operations}

LASL has a program to identify processes leading to mobilization and migration of radionuclides in dry burial environments and plans to develop engineering methods for prevention. They have a contract with the University of Texas to perform a literature search on nonradioactive hazardous waste disposal for identification of problems and engineering 
solutions transferrable to radioactive waste burial site operations (Jo78, EGH77) .

\subsection{Performance Evaluation}

LASL has never had a geologic monitoring program specifically directed toward the solid waste site. Insufficient data are available at present to design an effective monitoring program. Such hydrogeological parameters as variations in volumetric water content, unsaturated hydraulic conductivity, dispersivity, and distribution coefficients for critical radionuclides are needed. (USGS75, USERDA76b) 


\subsection{Site Characteristics}

\subsection{Location (Me76, Mo77, Pa74, Mul76, Har79)}

The Maxey Flats radioactive waste burial site, operated by the Nuclear Engineering Co., Inc. (NECO), is located on a flat-topped ridge in Fleming County, Kentucky, about $10 \mathrm{~km}$ northwest of Morehead, Kentucky, $110 \mathrm{~km}$ northeast of Lexinqton, Kentucky, and $2.3 n \mathrm{~km}$ snutheașt nf rinclnnati. Tho site occupies a $1.2 \mathrm{~km}^{2}$ (300 acre) tract of land, and is owned by the Commonwealth of Kentucky and leased to NECO. It is presently the largest commercial depository in the U.S., and contains approximately 408 of all commercially-generated low-level radioactive wastes buried in the U.S.

\subsection{Climate (Mo77, USEPA76, Mac79)}

The site is in a humid region. Rainfall varies with season, being least in the fall and most abundant in spring and early summer. The average annual rainfall at Flemingsburg (about $22 \mathrm{~km}$ northwest of the burial site) is $1170 \mathrm{~mm}$ (46 in). Rainfall in a 24-hour period during thunderstorms, common in spring and summer, frequently exceeds $70 \mathrm{~mm}$ and occasionally reaches 120 t'o $150 \mathrm{~mm}$. Heavy rains commonly cause flooding in the valleys.

Precipitation exceeds evapotranspiration by about $300 \mathrm{~mm}$ per year.

\subsection{Geology (Me76, Pa74, USEPA76, Mac79)}

Maxey Flats is directly underlain by shale, siltstone, and sandstone that gently dip to the southeast. The trenches are entirely within the Nancy Member of the Borden Formation. The Nancy Member is a poorly fissile, green shale, which is plastic when wet and which has siltstone and sandstone interbeds. The Farmer's Member, the lower unit of the Borden 
Formation, directly underlies the Nancy Member. It is a ledge forming, well sorted, indurated, very fine grained, evenly bedded, quartzose sandstone with shale interbeds less than $1 \mathrm{~m}$ thick and with well developed jointing fracturing. Open joints and bedding places are visible in out-crops of the sandstone and siltstone at the base of the Nancy Member in the Farmer's Member. The Henley Bed, a $1.5 \mathrm{~m}$ thick, greenish-gray clayey shale with $205 \mathrm{~cm}$ thick sandstone and siltstone interbeds, lies at the base of the Farmer's Member. The Henley Bed is underlain by Sunbury Shale and Bedford Shale, which in turn are underlain by the much thicker onio shale and Crab Orchard Formations.

The area is in a seismic hazard zone class 1.

1.4 Hydrology (Me76, Mo77, Pa74, CG076, Co79, Mo79)

The area is drained by tributaries of the Licking River, which joins the Ohio River near Cincinnati, Ohio. About 758 of the surface runoff from the site drains about $500 \mathrm{~m}$ to the east into No-Name Creek, a perennial stream; the remainder of the drainage is to the west into Drip Springs Hollow Creek and to the south into Rock Lick Creek. Both No-Name Hollow Creek and Drip Springs Hollow Creek join Rock Lick Creek which flows west into Fox Creek and then to the Licking River. The average annual flow of the Licking River is $100 \mathrm{~m}^{3} / \mathrm{sec}$ at Covington, Kentucky and that of the Ohio River is $3215 \mathrm{~m}^{3} / \mathrm{sec}$ at Louisville, Kentucky.

The Nancy Member in which the trenches are located is an aquitard in which the interstitial permeability is very low, $0.02 \mathrm{~cm} /$ day, and perched ground water occurs in the soil zone at a depth of 1 to 2 meters. There is a continuous ground water table at a depth of about 10 to 15 meters, but no regional aquifer. Ground water migration from the trenches occurs primarily in shale fractures. The main water table occurs in the Ohio 
Shale which supplies several domestic wells in the region; the perched water table supplies shallow wells on the site. Water levels in the deeper wells suggest that there may be vertical flow of ground water in the Nancy Member. Springs and seeps emerge from the Ohio Shale around the periphery of Maxey Flats.

The highly fissile nature of the Ohio and Sunbury Shales and the high degree of induration of siltstones and sandstones of the Nancy and Farmer's Members of the Borden Formation suggest that flow through these strata occurs primarily through joints and bedding planes. Water flow in the clay-shales of the Nancy and Farmex's Members and the Bedford Shale may also occur principally through fractures; some of these clay shales are plastic when wet (particularly those in the Bedford Shale) and may contain no open fractures when saturated.

The perennial creeks west and northweest (Drip Springs Hollow), east and southeast (an unnamed creek), and south (Rock Lick Creek) of the site comprise the approximate hydrologic boundaries of the local ground water flow system. The near-perennial nature of these creeks suggests, in this area of probably low infiltration rates and high runoff, that the creek discharge is primarily baseflow from the ohio Shale and/or the Craborchard Formation and possibly from the colluvium blanketing parts of the slopes around the site.

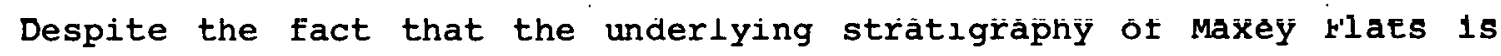
well known and its local hydrologic boundaries approximately defined, little data are available on the configuration of the water table(s), head changes with depth within the zone of saturation, transmissivities, or porosities of any of the strata older than the Nancy Member of the Borden Formation; and the data for the Nancy Member are marginal. The absence of 
substantive hydrogeologic data reflects, in part, the difficulties of obtaining hydraulic data from wells penetrating only aquitards and, in part, the absence of wells or test holes of proper construction tapping units older than the Nancy Member either at or in the imediate vicinity of the site.

\subsection{Ecology (Me76, Mo79)}

The natural vegetation of the area is heavy deciduous forest. Part of the uplands and valleys have been cleared for agricultural use. The major agricultural crops are tobacco, corn, and forage for beef and dairy cattle. Three commercial dairy farms are located within $4 \mathrm{~km}$ of the site; the closest is about $2 \mathrm{~km}$ to the south-southwest. Family vegetable gardens are common. Game in the area includes deer, quail, grouse, raccoons, squirrels, rabbits, oppossums, etc. Fish occur in Crane Creek and Fox Creek, but there is no sufficient water in Rock Lick Creek to support fish throughout the year. Only a few minnows, crayfish and some benthic organisms have been observed in Rock Lick Creek.

\subsection{Licensing}

2.1 Date and Nuthority of Lienense (C173, USNRC77, Ma76, USEPA76, USNRC76)

The license of commercial burial operations at Maxey flats was originally issued to the Nuclear Engineering Co., Inc. on October 22, 1962, by the State of Kentucky, which had entered into agreement with the U.S. Atomic Energy Commission in March, 1962 giving the state licensing authority. The license is authorized under Kentucky Board of Health Regulations KRS 152,105, et seq. The administering body is the Kentucky Department of Health, the Radiation Health Program. 
2.2 License Conditions (C173, Mul76, USNRC77, Ma76, USEPA76, Har79)

The 5 page license permits the Nuclear Engineering Co., Inc. to "receive, possess, package, store, and dispose of radioactive material...subject to all applicable rules and regulations." There are 24 conditions specified and the license refers to state and Federal regulations and standards with respect to transportation, safety, and radiation protection.

Solid wastes, except nhjerts with Induoed aotivity and no reiuveable contamination, must be packaged for burial. Dewatered resins in strong, tight containers are acceptable for burial, but filter aids must be solidified. Spent filter cartridges must be in a disposable container.

Initially the operator was authorized to receive and solidify low-level radioactive liquids, but the license was amended in 1972 to restrict further receipt of liquids. Liquids must now be solidified with coment or ahcmicals.

Gaseous tritium and ${ }^{85} \mathrm{Kr}$ are accepted for burial; the amount of tritium cannot exceed 1000 Ci per package and the ${ }^{85} \mathrm{Kr}$ munt he at $\mathrm{r}$ atmosphere pressure or less.

The amount of radioactivity that may be buried is essentially unlimited, but the limits for possession of unburied materials without special consideration is $15,000 \mathrm{Ci}$ of non-TRU byproduct material, with the exception of ${ }^{226} \mathrm{Ra}$ which is limited to $0.5 \mathrm{ci}$. Unhuried source material ia limited to 10,000 pounds and special nuclear materials to $350 \mathrm{~g}$ of ${ }^{235} \mathrm{U}$, $200 \mathrm{~g}{ }^{238} \mathrm{U}$, and $200 \mathrm{~g} \mathrm{Pu}$. If larger quantities are to be received, the licensee must evaluate the proposed packaging and handling and determine that the proposed operation can be conducted without undue risk to workers and the public; a specific letter of authorization is required. 
Radioactive wastes with associated chemically toxic wastes may not be buried if the chemical toxicity exceeds the radiological hazard. Since 1974 the burial of wastes with greater than $10 \mathrm{nCi} / \mathrm{g}$ has been prohibited.

A daily log of waste received is required to be maintained by the site operator showing quantity, type, and origin with container dose rates and transport class specified. Periodic summary reports are required to be made on waste burials made during the reporting period.

Burial trench specifications are indicated including provisions for water collection and for covering. A monument indicating basic information on buried material is required to be placed at each end of filled trenches. Determination of radioactivity levels in surface and ground water is required, and soil and vegetation sampling is specified.

Other license terms of an administrative nature include:

a. Designation of operators and radiation safety or health physics staff.

b. Location of disposal operations.

c. Burial charges.

d. Leasing of land.

e. License fees.

f. Insurance.

\subsection{Operation}

\subsection{Dates of Operation (Me76, MO7\%, USNRC76)}

The State of Kentucky authorized the establishment of a commercial waste disposal facility in 1962 and burial operations at the Maxey Flats site began in May, 1963. 
3.2 Operations Techniques (Me76, Mo77, Cl73, De77, Le77, Mul76, USDOE78a, USEPA76, Mac79, Har79)

The solid wastes are buried in large rectangular trenches which are 60 to $150 \mathrm{~m}$ long, 6 to $24 \mathrm{~m}$ wide, and 6 to $8 \mathrm{~m}$ deep. The bottom on the trench must have a minimum slope of 18 to a sump and standpipe at the lowest level.

The wastes are received in 210-1iter (55 gal.) steel drums as well as plastic, wood, and cardboard containers. Trenches are excavated to full. size before burial begins. After being logged in and surveyed, the wastes are dumped randomly into the trenches from the truck, beginning at one end of the trench. Particularly large items and those items emitting high levels of radiation in casks are emplaced by crane. Each day the wastes are covered temporarily with a reinforced plastic cover.

When the trench is filled it is. covered with a minimum of $1 \mathrm{~m}$ of clay applied in layers and compacted with a sheepsfoot roller; water is pumped from the trench. The cap is mounded to $0.6 \mathrm{~m}$ above the ground to encourage runoff and a final layer of topsoil is added. The cover is then seeded with fescue and clover. The radiation level at the surface of the completed trenches is not allowed to exceed $2 \mathrm{mR} / \mathrm{hr}$. A clay berm is constructed around the trench for water control.

When the trench is completed, a monument is placed at the end of the trench. The monument records the number of the trench and the date of closure. This allows cross reference to the records containing additional information. Public access is prevented by fencing of the trenches and working areas.

Written records of disposal can be cross referenced to monuments exected at the end of each completed trench which have the number of the 
pit and the date of closure inscribed. The records contain information on: The location and definition of trench boundaries. The total amount of radioactivity, source material, and special nuclear materials.

Radionuclides with the greatest hazard potential.

Date of completion of the burial operation.

Volume of waste in the trench.

3.4 Usage (Me76, Mo77, C173, De77, Le77, USDOE78a, Mac79, Har79)

During the period between 1963 and 1977 approximately 140,000

$\mathrm{m}^{3}$ of waste containing more than 2.4 million curies of radioactive material, $400 \mathrm{~kg}$ of special nuclear material and $230,000 \mathrm{~kg}$ of source material have been deposited. The cumulative waste volume has increased nearly exponentially, from $2200 \mathrm{~m}^{3}$ in the first year to about $70,000 \mathrm{~m}^{3}$ in 1971, and $121,000 \mathrm{~m}^{3}$ in 1975. Most of the increase in the later years is attributed to nuclear power plant operations.

The wastes include relatively long-lived fission products, many activation products and the actinides. Although concentrations of transuranium radionuclides have been limited to $10 \mathrm{nCi} / \mathrm{g}$ since 1974 , it is estimated that $80 \mathrm{~kg}$ of ${ }^{239} \mathrm{Pu}$ plus additional quantities of other plutonium isotopes have been buried at the site. Tritium is probably the most abundant radionuclide in the trenches.

The commercial capacity of the site is estimated to be $31 \times 10^{5} \mathrm{~m}^{3}$. As of January 1977 the Maxey Flats facility was closed.

4.0 Monitoring (Me76, Mul76, USEPA76, CG076, USNRC76)

The operator monitors radioactivity concentrations monthly in eight onsite wells and quarterly in offsite water samples. Soil and vegetation 
samples are taken quarterly at four onsite and four offsite locations. A continuous air monitor is operated.

Because of the rapid increase in the quantities of radioactive waste buried at the site and the concern that infiltration of precipitation into the trenches could give rise to radionuclide migration, the Kentucky Department for Human Resources (KDHR) decided in 1971 that additional studies were needed. In late 1972, elevated levels of radioactivity were detected in the Maxey Flats environs. KDHR initiated a special 6 month environmental monitoring study in November 1973. Fourteen monitoring wells were constructed around the perimeter of the controlled site and more than 50 samples were collected and analyzed for ${ }^{238} \mathrm{Pu}$ and ${ }^{239} \mathrm{Pu}$. In addition, the Environmental Protection Agency conducted independent invest1gations.

Plutonium contaminantion was found in nine wells and in all 20 suspended sediment samples. Tritium, ${ }^{60} \mathrm{Co},{ }^{134} \mathrm{Cs}$, and ${ }^{137} \mathrm{Cs}$ were also found in some wells.

\subsection{Identification of Problem Areas}

\subsection{Site}

Trenches at Maxey Flats are filled and covered with materials which have higher porosity and permeability than the formation in which they are excavated. This combined with the high rate of precipitation results in a "bathtub effect" in which the water level builds up in the trench, exposing the waste to continued leaching unless special efforts are taken to remove the water. (Me76, De77)

The Nancy Member in which the trenches are excavated has a very low interstitial permeability and is fissured. It is likely that the fissures are responsible for serving as the conduit for most groundwater flow. The 
fractured nature of the formation reduced the effective sorptive action of materials passing through it. (Me76, Pa74)

Additional information is needed on the extent and orientationof fractures and on the direction and rate of groundwater movement. (Pa74, CGO76, USNRC76)

\subsection{Waste}

Plutonium and other radionuclides $\left({ }^{3} \mathrm{H},{ }^{60} \mathrm{Co},{ }^{89} \mathrm{Sr},{ }^{90} \mathrm{Sr},{ }^{134} \mathrm{Cs}\right.$, and ${ }^{137} \mathrm{Cs}$ ) have been detected in groundwater and sediment samples taken in the area near the waste trenches at Maxey Flats. However, the form of the plutonium was not determined and the routes and mechanisms of the migration are not well understood. (Me76, Mo77, Pa74, USNRC77, Ma76, USEPA76, CGO76, USNRC76)

Elevated tritium levels have been detected in the milk from cows drinking water from Rock Lick Creek and in local garden products. (Mo77)

During the early years of operation, the estimates of the quantity and radioactivity of the waste received for burial were only approximate and no attempt, generally, was made to specify the isotopic content of the waste. As a result, estimates of the inventory are not reliable. (Ad78, Sat 75$)$

\subsection{Operation (Me76, Mo77, USNRC77, CGO76, USNRC76)}

Water accumulated in completed trenches in the early 1970's and the State of Kentucky required NECO to initiate a water management program consisting of pumping water from the trenches to above-ground storage tanks, evaporating the liquids, and disposing of the heels from the evaporator as solids. Atmospheric effluents from the evaporator have contained radionuclides with tritium being the predominant nuclide. Water 
management poses a long-term operational problem for the site. (Me76, Mo77, USNRC77, USEPA76, Mo79, Har79)

\subsection{Performance Evaluation}

The increase of radioactivity in onsite groundwater and offsite envixonmental samples has caused concern about the long-term suitability of the Maxey Flats site for containing radioactivity. It is generally agreed that the current levels of radioactivity cause no immediate concern for radiological health, but the geologic and hydrogeologic characterization of the site is not adequate for making an accurate projection of radionuclide migration. (Me76, Mo77, Pa74, USNRC77, CG076, USNRC76)

The environmental monitoring program conducted at the site is not adequate to meet the objectives of such a program, which are to:

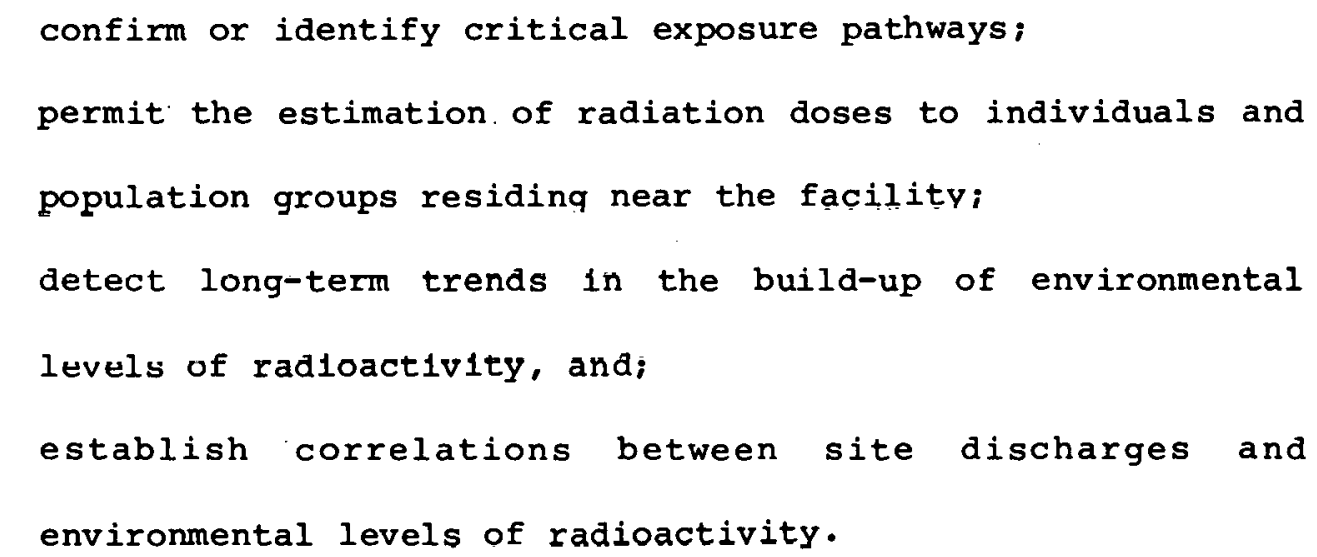

(M077) 
Oak Ridge National Laboratory, Oak Ridge, Tennessee

\subsection{Site Characteristics}

\subsection{Location (NAS76, USGS76)}

The Oak Ridge National Laboratory is located in eastern Tennssee about $40 \mathrm{~km}(25 \mathrm{mi})$ west of Knoxville and $240 \mathrm{~km}(150 \mathrm{mi})$ east of Nashville. The

reservation of about $260 \mathrm{~km}^{2}$ is bounded on the northeast, southeast, and southwest by the Clinch River and on the northwest by Black Oak Ridge. The area surrounding the reservation is generally rural in character.

\subsection{Climate (NAS76, USGS76, Mac79, Ad78, USERDA76a)}

The climate at ORNL is typical of the humid Appalachian region. The mean annual precipitation is about $1360 \mathrm{~mm}(53.5 \mathrm{in})$ and is predominantly in the form of rain, although snow can represent a signficant portion of winter precipitation. Maximum precipitation occurs from January to March with a secondary peak in July.

The mean temperature is $14.4^{\circ} \mathrm{C}\left(58^{\circ} \mathrm{F}\right)$. Evaporation measured in eastern Tennessee with conditions similar to ORNL ranges from about 1050 to $1100 \mathrm{~mm}$ ( 41 to $43 \mathrm{in}$ ). Thus precipitation exceeds evaporation on an annual basis, but there may be periods during hot dry weather when there is an evaporation stress.

The humid climate of Oak Ridge has several effects that relate to the behavior and safety of burial grounds. The high precipitation causes the water table to occur at shallow depths and accounts for seasonally large stream flow. The stream density is high and ground water residence time is short. Rainfall affects the composition of the natural vegetative cover; the infiltration of large amounts of aclalc leachate from decaying 
vegetation has lowered the soil $\mathrm{pH}$ and influences the nature of the clay minerals formed.

1.3 Geology (NAS76, USGS76, Mac79, DM78, USERDA76a)

The Oak Ridge Reservation is located in the ridge and valley province, which is characterized by parallel ridges of sandstone, shale, and cherty dolomite, separated by valleys of less weather resistant limestone and shale. The ridges run from southwest to northeast and the rocks lie about 30 to 40 degrees to the southeat.

The lowcot formation ic the Pome Formation, sonsisting of even-bedded, very fine-grained sandstone and shale. It forms rldges in the area. There are no burial grounds in the Rome Formation because it is exposed on moderately steep slopes, the soil covering is shallow, and it is difficult to excavate.

Overlying the Rome is the Conasauga Group which is about 460 meters $(1,500 \mathrm{ft})$ thick. It consists of shale with siltstone beds and lenses of gray limestone. The Conasauga Group underlies the valleys of the region. Small anticlines and synclines are a common feature of the conasauga Gruup. The Knox Group lies above the Conasauga and is up to $800 \mathrm{~m}(2,600 \mathrm{ft})$ thick. It consists largely of chertydolomite and forms ridges. There are numerous sinkholes in areas where it outcrops and sizeable springs issue from its base. The Knox Group is considered unsultable fur wasle disprsal because the migration of water in cavernous ruck, particularly at depth, is unpredictable and unmonitorable.

The Chickamauga limestone, a. $520 \mathrm{~m}(1,700 \mathrm{ft})$ thick interbedding of limestone and shale, l1es above the Kiux. Fractures and solution openings occur in the Chickamauga but it is believed to be free from the large openings found in the knox. However, it is now considered undesirable for 
waste disposal.

The Oak Ridge SWDA's are located in Bethel and Melton Valleys and are separated by Haw Ridge. Bethel Valey includes SWDA's 1, 2, and 3 is underlain by Chickamauga Limestone.

Melton valley includes SWDA's 4, 5, and 6 . It is underlain by Conasauga Shale. At the lower elevations the weathered zone has an average depth of 1.2 to 1.5 meters and at the higher elevations 6 meters; the weathered zone sometimes ranges up to 10-12 meters thick. The shale was selected for waste disposal because of its impermeability.

The inhomogeneity of the strata, the irregularity of openings, and the complex folding of the formation makes it difficult to predict the movement of water and the migration of radionuclides.

The soils of the reservation have developed under forest conditions and are strongly leached and low in organic matter. The Conasauga Shale weathers to form illite and vermiculite. The greatest permeability is found at the transitional zone between the fresh and weathered rock and it is in this zone that the water table commonly occurs.

The area is classed as a seismic hazard zone 2. In the southeastern United States there are only two zones of highest risk (zone 3 ), the Mississippi Valley and Charleston, S.C., both of which are about $740 \mathrm{~km}$ (400 mi) from ORNL. On November 30,1973 an earthquake of intensity of IV to $V$ on the Modified Mercali scale occurred about $50 \mathrm{~km}(30 \mathrm{~m} i)$ to the southeast, but there was no observed dmage on the reservation.

1.4 Hydrology (NAS76, USGS76, DU75, Du76, Mac79, DM78, USERDA76b, USERDA76a, We79)

All of the surface and subsurface drainage from the burial sites at ORNL are into White Oak Creek or into Melton Branch which runs into White 
Oak Creek. White Oak Creek is impounded $1 \mathrm{~km}(0.6 \mathrm{mi})$ upstream from its confluence with the Clinch River. The impoundment, Whiteoak Lake, serves as a settling basin for contaminated sediment and, if necessary, can serve for the detention of discharge for a short period of time. The Clinch River discharges into the Tennessee River and in turn into the Mississippi River.

The average annual flow rates of the various surface water bodies is given in Table 1.

There is no regional aquifer in the vicinity of ORNL and few data are available on regional groundwater flow patterns. Infiltration rates range from 5 to $40 \mathrm{~mm}$ per hour. Precipitation would be expected to infiltrate in the upland areas and discharge locally to provide the base flow of small streams feeding into the $\mathrm{Cl}$ inch River.

The Knox dolomite is solid and massive where unweathered, but its permeability has been considerably increased in some places, by fracturing. Sinkholes and caverns have been formed by enlargment of the fractures by dissolution.

The Chickamauga limestone has a very low posority. Fractures between the beds transmit water; some of these fractures have been enlarged but not to the extent of those in the Knox dolomite.

The permeability of the Rome sandstone is low'and lts abllity lo hold and transmit water is due largely to fractures between its beds.

The Conasauga shale is essentially impermeable below 38 meters (125 ft) and subsurface water is essentially restricted to the zones above this depth. It is weathered to a depth of 3 to 6 meters $(10$ to $20 \mathrm{ft}$ ) and this zone, which has thin partings and fractures along and across the bedding places, can transmit water although the permeability is small compared to 
Table 1. Annual Flow Rates Downstream from the ORNL Burial Grounds

Station

Average Annual Flow Rate $\left(\mathrm{m}^{3} / \mathrm{sec}\right)$

White Oak Creek
(0.1 mile above Melton Branch)
0.27

Melton Branch
(0.1 mile above White 0ak (reek)
0.07

White Oak Creek (at Whiteoak Dam)

0.38

Clinch River (Oak Ridge, Tennessee)

Tennessee River

(Chattanooga)

1,045

Mississippi River

(Memphis)

13,365 
water supply standards. Groundwater flow is mainly through the fractures parallel to the strike and the velocity of low is higher than anticipated from the measured permeability. The greatest permeability is associated with the transition between the weathered and unweathered zones.

In the early years of operation at ORNL, SWDA's were sited near the source of the waste and SWDA's 1, 2 and 3 were underlain by Chickamauga limestone. The groundwater table was 1.5 to 10 meters below the surface in these three areas. SWDA 1 was closed when ground water was found in one of the burial trenches. Trenches in SWDA 3, located west of SWDA 1 , also often contained water during the rainy season.

After the first few years of operations it was decided that the Conasauaga shale was the most suitable formation for waste disposal and since this decision was made SWDA's 4, 5, and 6 have been located in this unit.

In these areas the water table is usually between 1.5 to $4.5 \mathrm{~m}$ (5 to $15 \mathrm{ft}$ ) below the surface and conforms generally with topography; the depth to ground water fluctuates in both time and space and can range from 0 to as much as 7.5 meters $(25 \mathrm{ft})$. Burial trenches were initially constructed above the top of the zone of saturation, but water is sometimes observed in the trenoheo.

Groundwater is replenished by infiltration of precipitation and seasonal recharge is received from White oak Creek when the water table falls below the creek level. Discharges of groundwater occur at springs and seeps along the channel of White Oak Creek and by evapotranspiration. There is no discharge from wells.

The best estimate for the rate of groundwater movement in the Conasauga shale is about $0.17 \mathrm{~m}(0.56 \mathrm{ft})$ per day in the area where seepage 
pits were formely operated; a range of 0.05 to $0.74 \mathrm{~m}(0.5$ to $2.5 \mathrm{ft})$ per day has been observed in the weathered shale and from 0 to $7.5 \mathrm{~m}$ ( 0 to 25 ft) per day in fractured shale.

Several semi-permanent perched water tables and associated seeps have developed at SWDA 4 due to the "bathtub effect" which results from backfill of the trenches with material more permeable than the surrounding shale. Springs have also developed at SWDA 5. Until late 1973, the area was covered with fill in thicknesses ranging up to 6 meters, resulting in a general rise in the water table.

\subsection{Ecology (Ki76)}

The primary vegetation of the site is the oak-hickory association. It is typified by extensive stands of mixed yellow pine and hardwoods as well as oak and hickory. Since 1947, over 2000 hectares of the Reservation havre been planted in loblolly pine.

A comprehensive listing of plant species which potentially occur on the Oak Ridge Reservation has been compiled by Mann (1975). There have been no studies on invading species specific to the burial grounds, however the general pattern of succession on abandoned land is one in which the earliest phase is dominated by annual forbs and grasses such as ragweed and crabgrass. The next phase is dominated by biennial and perennial forbes such as horseweed, primrose, many species of Aster and other composites. The perennial grass phase, usually dominated by broomsedge, follows. Fescue is dominant at this stage in areas such as power line corridors where it has been planted for erosion control. Areas which receive Periodic mowing are generally dominated by fescue or other grasses, rapidly growing weedy annuals, and low growing perennials. The grass phase is generally followed by a shrub phase as the grassland is invaded by rapidly 
growing shrubs, woody vines, and tree seedlings such as sassafras, red cedar, pines, and various hardwoods.

The animal populations captured or observed on the Oak Ridge Reservation are small mammals (mice, chipmunks, land shrews), and larger mammals (squirrels, opossum, rats, muskrats, foxes, weasels, bobcats, and deer). The variety of wooded and open areas as well as edge communities creates favorable habitats for a wide variety of bird species.

Mammalian species inhabiting old field or disturbed areas are quite similar, whether the vegetative cover is grass, or tree seedlings and shrubs (Ki76). In a 1 hectare study area indicative of these habitats, the dominant vegetation was tall fescue, and sericia lespedeza. Small mammals trapped were cotton rats, white-footed mice, a golden mouse, a rice rat, short-tail shrews, and eastern harvest mice.

\subsection{Licensing}

The Oaje Ridgc National Laboratory is operated by Ininn Carhide Corporation, a prime contractor for the U.S. Department of Energy, and is not a licensed facility. The operations are regulated by the U.S. Energy Research and Developmement Administration Manual Chapters.

\section{U Uperations}

\subsection{Dates of Operation (Bu72, Du75, DM78, We79).}

Soils have been used for the burial of radioactive wastes at ORNL since the beginning of operation in 1943. Six burial grounds, numbered consecutively in order of their first use, are located in Melton and Bethel 
Valleys. The starting and closing dates of the 6 SWDA's are given in Table 2.

The first three SWDA's were located for convenience to the site of waste generation and without prior geologic and hydrologic exploration. SWDA 1 was closed because water was found standing in trenches and SWDA 3 presented problems of excavation as it was underlain with rock. SWDA's 4, 5 , and 6 were located in Conasauga shale as it was determined to have the best properties for waste disposal operations.

3.2 Operations Techniques (NAS76, Bu72, USGS76, DU75, Du76, Mac79, USERDA76a)

The conasauga shale in which the SWDA's are located is weathered and is easily excavated by power equipment. The size and shape of the trenches are variable depending on the terrain and soil conditions. Trenches range from 15 to $120 \mathrm{~m}$ ( 50 to $400 \mathrm{ft}$ ) l.ong, 2.4 to $9 \mathrm{~m}(8$ to $30 \mathrm{ft}$ ) wide, and 2.4 to $4.5 \mathrm{~m}$ ( 8 to $14 \mathrm{ft}$ ) deep. The bottom of the trench is at least $1 \mathrm{~m}$ above the highest observed elevation of the groundwater table and the trenches are at least $1.5 \mathrm{~m}$ apart.

Waste is placed into the trenches to within $1 \mathrm{~m}$ of the surface and backfilled immediately with the excavated shale. The backfill material is at least $1 \mathrm{~m}$ thick and graded to the original ground surface level, except for a few trenches which have been sealed experimentally $0.5 \mathrm{~m}$ below the surface. After backfilling the cover is fertilized and limed then seeded with Kentucky 31 fescue, bluegrass and rye in a 2:1:1 ratio. After the initial seeding, natural vegetation may take over but the area is mowed to prevent growth of scrubs and trees. In cases of erosion problems or trench cap sinking the area is spot seeded.

SWDA plans included the marking of trench ends with reinforced 
Table 2. Dates of Operation of ORNL Burial Ground Areas

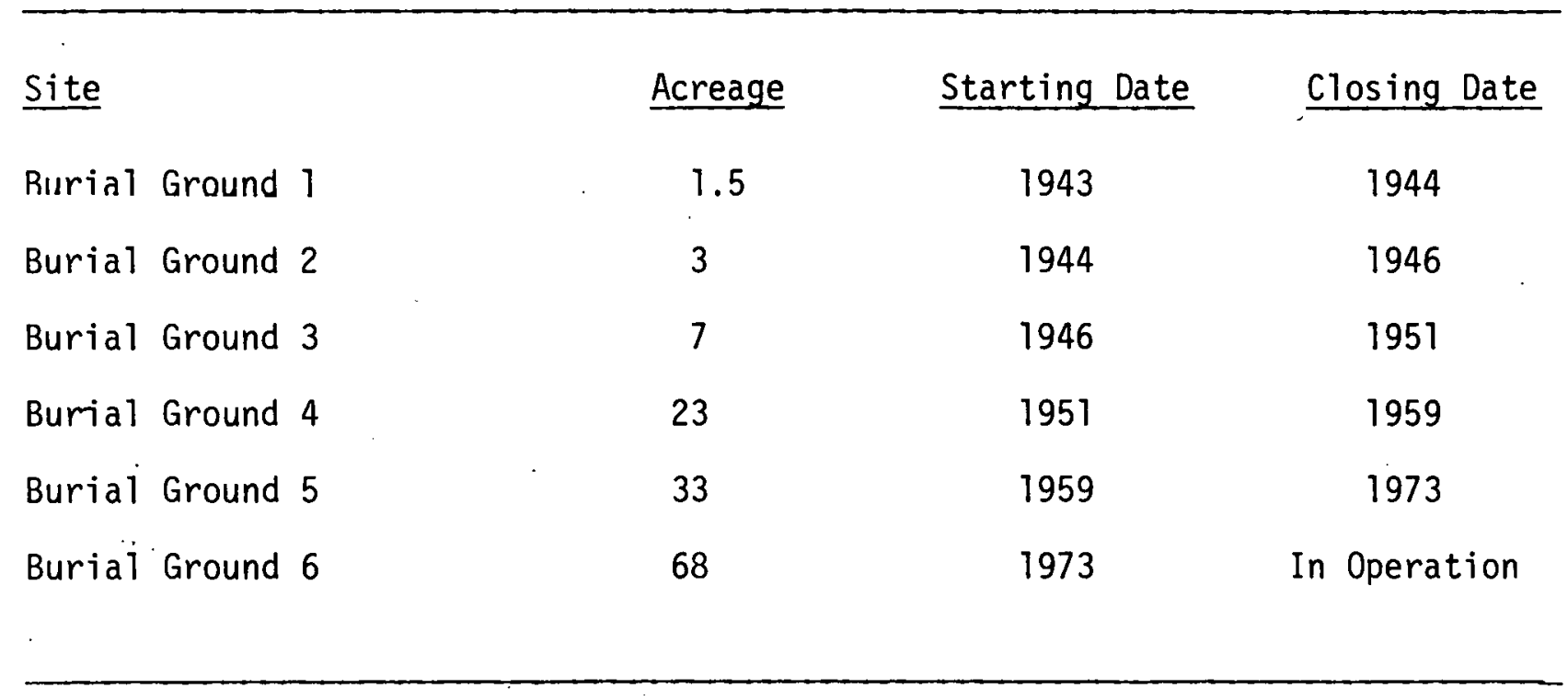


concrete posts and/or corrugated steel pipes to serve as reference points for monitoring trench conditions and for surveys.

During the operation of SWDA's 1, 2, and 3 wastes were dumped into trenches and backfilled. Records were not kept of the quantity or kind of materials buried. It is likely that fluid combustibles were buried, and is also likely that very little fissionable material was in the waste due to the efforts made to conserve it.

Currently, trenches are sloped to one end for collection of water and a $15 \mathrm{~cm}$ metal casing serves as a montoring well. To reduce the effects of groundwater flow the basin above SWDA 4, a surface runoff collector consisting of a shallow, asphalt-lined ditch was installed along the north side of the burial ground to divert surface runoff. In SWDA 5, sheets of 0.01 inch thick polyvinyl choride have been installed to form a seal of over 4 trenches. Some trenches were covered with a mixture of native soil and bentonite to test its effectiveness in reducing infiltration and trees and other deep-rooted plants were removed to reduce biological transport of radionuclides.

Computer records are kept for every load of radioactive waste buried. Periodic surveys establish coordinates of trench boundaries and auger-well locations. This information is transferred to a plat of the burial site, and usage of the acreage is computed. This log was initiated in 1961.

Historical records are scant. No records were kept for SWDA's 1 and 2, and those for SWDA's 3, 4, and a part of 5 were accidentally destroyed by fire in 1961. Previous records were limited to special or nonroutine burials involving SS accountability and were not accurate with respect to the content of radioactivity. However, the amount of radioactivity in buried wastes is estimated to be small compared to the more than one 
million curies discharged as liquids into open-pits and covered trenches prior to 1966, when surface disposal of liquid waste was discontinued.

\subsection{Special Management Techniques (NAS76, Bu72)}

From 1955 to 1965, ORNL was the Southern Regional Storage Area for solid radioactive waste and received shipments of about $28,000 \mathrm{~m}^{3}$ during this time.

Material that cannot be safely disposed of in open trenches and materials that require special identification and separation from other wastes, are buried or stored via special techniques. Transuranium wastes are presently stored, in cans in lined auger holes or in temporary covered structures to ensure retrievability. Other special wastes are placed in auger wells, which vary from 15 to $75 \mathrm{~cm}$ in diameter and are 6 meters deep. Waste is placed in the well and covered with earth until the radiation is reduced to an acceptable level. This operation is repeated until the well is filled to within $0.6 \mathrm{~m}$ of the surface. The well is then capped with concrete and marked with a disk showing the well number.

3.4 Usage (NAS76, Bu72, USGS76, Mac79, USDOE78a, Mac79, USDOE78a, USERDA76a， Ga79)

Records of land burial of solid radioactive waste prior to 1961 do not exist as no records were kept auring the early years of uperatiun and existing records were accidentally destroyed by a fire in 1961. From 1961 through June 30,1974 about $87,500 \mathrm{~m}^{3}$ of waste were buried in an area of 7.45 hectares (18.4 acres). It is estimated that approximately 28 hectares (62 acres) of land have been used to dispose of $1.87 \times 10^{5} \mathrm{~m}^{3}$ of solid waste as of the end of 1976 at ORNL. This includes about $28,000 \mathrm{~m}^{3}$ of solid waste received for burial from off-site during the period 1955 to 1963 when ORNL was the Southern Regional Storage Area for solid waste. 
The inventory of long-lived radioactivity, exclusive of tritium in the burial grounds is estimated to be less than 10,000 curies. There may be more than 50,000 curies of tritium, 13,000 grams of transuranics, and 100 $\mathrm{kg}$ of uranium disposed of on-site.

The current rate of burial is about 2000 to $3000 \mathrm{~m}$ annually, requiring about a third of a hectare $(0.85$ acres $)$. This means that the remaining 8 acres of capacity at ORNL will be filled within 10 years.

\subsection{Monitoring (NAS76, IISGS76, Du75, USERDA76a, Rob80)}

The SWDA's at ORNL have received only infrequent attention with respect to monitoring because it was considered that these areas posed a much less serious threat to the environment than that arising from the discharge of liquid wastes into the ground or directly into surface waters. The earliest reference to surveillance of the burial grounds dates back to 1946 when a ground survey of radiation levels and determination of the alpha activity in seven soil sample was made at SWDA 1.

Surface drainage has received more or less continuous surveillance since 1943 when sampling of White Oak Creek began. Monitoring of White Oak r.reek was not undertaken for the purpose of monitoring the burial grounds, but contamination arising from most of the burial grounds leave the reservation only through this watercourse. The discharge across Whiteoak Dam is monitored by a continuous and proportional flow monitor that samples in proportion to discharge. Composite samples are analyzed weekly for gross beta activity and for specific radionuclide.

During the latter 1950 's an unaccountable increase in radiostrontium was noted in white oak Creek between the plant and Whiteoak Dam. Continuous and proportional samples were installed above the confluence of 
Melton Branch and White Oak Creek on each stream and on. White Oak Creek at the point of surface discharge from the plant and at a point above the effluent outfall. Thus, the system provides information on the contaminant loading contributed from each valley.

There is no routine monitoring of groundwater, soil, vegetation, or air conducted specifically for the burial grounds. There are occasional air samples taken during waste disposal operations and radiation surveys are made at the.ground surface on a quarterly basis (more often during the wet season).

There have been special studies to monitor groundwater in SWDA's 4, 5, and 6. A groundwater monitoring system of 37 shallow wells was installed along the east end of SWDA 4 during the summer of 1973. The cased wells are on 30 -meter centers and penetrate the floodplain of White Oak Creek to a maximum depth of 3.7 meters. An extensive network of wells now exists in SWDA's 3, 4, 5, and 6 which will be part of routine operational monitoring by the end of fiscal year 1982 (Rob80).

\subsection{Identification of Problem Areas}

\subsection{Site}

SWDA 4 is a major rontributer of ${ }^{90}$ Sr to White nak ripek aigul the Clinch River. The landfill was improperly designed and not only serves as a catchment for precipitation but also receives runoff from upslope. The "bathtub effect" at ORNL is aggravated by the orientation of trenches with their long axes downslope; the effect could have been reduced by paralleling the trenches with the hill-slope contours. Proper covers could also reduce the infiltration of precipitation. '(NAS76, Du75, DM78, USERDA76a, WE79). 
Erosion is a minor problem in some parts of the SWDA's. (USGS76, DM78) Ongoing construction activities continuously alter the hydraulic flow patterns at the SWDA's. (DM78)

\subsection{Waste}

Leachates have been observed at surface seeps and in groundwater as a result of operation of the waste burial grounds at ORNL. Tritium contaminated waste in SWDA 5 contributes about 858 of the tritium released into the Clinch River via White Oak Creek. Little is known about the upward movement of groundwater and contamiants in or near the burial grounds, but it is expected that evaporative stresses during hot weather could release tritium into the atmosphere and possibly transport other contaminants in solution to the root zones of trees and other deep-rooted vegetation. (NAS76, Bu72, Du75, DM78,Ad78, USERDA76a, CGO76, We79)

The chemical mechanisms affecting radionuclide transport in the ground are not well understood and the available data is not sufficient to develop an understanding and preliminary prediction of radiocontaminant migration in groundwater. (DM78, Du79).

The buried wates in some parts of the burial grounds are often in contact with groundwater and the distance to surface waters is short. Thus, the retardation of radionuclides by interaction with the ground offers the only significant impediment to radionuclide migration. (DM78, USERDA76b, Ad78, We79)

\subsection{Operation}

A central radioactive solid waste handling facility capable of volume reduction and packaging of all wastes is needed to prolong the useful life of the current waste burial grounds. (Bu72)

Historical records of the identity, quantity, and concentrations of 
wastes buried at ORNL are incomplete. Specific information is lacking concerning the exact location of trenches and their inventories. (USGS76, NAS76, DM78)

The backfill material covering several trenches has sagged and in a few cases has collapsed, exposing the contents of the trenches.

\subsection{Performance Evaluation}

Transport of radionuclides through the unsaturated zone and through fractured media cannot be simulated with reliable results, particularly when the mechanisms of interaction with the formation are not well understood and site specific data has not been obtalned for several imporțant geohydrological paramters. (DM78, USERDA76b, Du79)

The monitoring program is not sufficient to define the radiologic conditions in the SWDA's. (DM78) 
Richland, Washington

\subsection{Site Characteristics}

\subsection{Location (Mul76, USNRC77, USNRC76)}

The Richland commercial waste burial operation is situated on Federal land about $16 \mathrm{~km}$ ( 10 miles) northwest of Richland, washington. The land is leased to the State of Washington and then to Nuclear Engineering Co., Inc., who operates the facility.

1.2 Climate (USERDA76a, NAS76, Ge77, Mac79, USERDA76b)

The climate of the site is described under Hanford, Washington.

1.3 Geology (USERDA76a, NAS76, Ge77, Br77, Mac79, USERDA76b)

The geology of the site is described under Hanford, Washington.

1.4 Hydrology (USERDA76a, NAS76, Ge77, Br77, Mac79, USERDA76b, Ad78)

The hydrology of the site is described under Hanford, Washington.

1.5 Ecology (Ge77, Br77)

The ecology of the site is described under Hanford, Washington.

\subsection{Licensing}

2.1 Date and Authority of License (Mul76, USNRC76, USERDA76a, Ma76)

The facility was originally licensed for commercial operation in 1965 by the U.S. Atomic Energy Commission. Currently, the Nuclear Engineering Co., Inc., is licensed by the state of washington, a U.S. Nuclear Regulatory Commission (NRC) agreement state under the authority of the Nuclear Energy and Radiation rontrol Act RCW 70.98 and Rules and 
Regulations. The administering authority is the washington state Department of Social and Health Services. It is also licensed by the NRC to possess special nuclear materials. In most cases of commercial land burial operations, the states have assumed responsibility for assurance of long-term care and maintenance; but responsibility for the Richland site will eventually revert to the Federal government, which owns the land.

The site is currently open and accepts transuranic wastes.

\subsection{License Cond1tions (Mu176, Ma76)}

The 2 page license permits the Nuclear Engineering Co., Inc., "to receive, possess, repackage, store and dispose by burial in the soil... waste materials". The license specifies 16 conditions with respect to material; form, and amounts of material for burial and refers to a separate letter by the state of Washington with respect to procedures for trenching and to State and Federal regulations pertaining to atomic energy, radiation protection, health, environmental protection, and transportation. The rtransportation regulations relate to packaging, marking, and labeling of th?r epackage, pilacarding of transporting vehicles, and reporting of transportation accidents.

Solid wastes must be packaged, but spent filter cartridges in a disposable container are acceptable without solidification. Dewatered resins are acceptable as solid waste.

Liquids must be solifified before burial, but bulk liquid shipments are accepted and the Richland site facility has the authority and capability for their solidification. Liquid scintillation vials are accepted for burial.

Gaseous wastes are accepted for disposal but toxic wastes are not accepted. 
The limit for possession of non-transuranic material is 60,000 curies.

A daily $\log$ of waste received is required to be maintained by the site operator showing quantity, type, and origin with container dose rates and transport class specified. Periodic summary reports are required for submission to the state, including volume, activities, grams of special nuclear material, pounds of source material, curies of byproduct material, and form of waste handled during the reporting period.

Burial trench specifications are indicated. A separate, permanent concrete or metal marker indicating basic information on buried material is required to be placed at each end of filled trenches.

Determination of radioactivity levels in surface and groundwater is required, and soil and vegetation sampling, on a quarterly or monthly basis, is specified.

Other license terms of an administrative nature include:

a. Designation of operators and radiation safety or health physics staff.

b. Location of disposal operations.

c. Burial charges.

d. Leasing of land.

e. License fees.

f. Insurance.

\subsection{Uperation}

3.1 Dates uf Operationi (Mu176, USDOE78a).

The site was licensed and opened for operation in 1965.

3.2 Operating Techniques (Mu176, USNRC77, USERDA76a)

Trenches are constructed with conventional earth moving equipment. 
Typical trenches are $90 \mathrm{~m}$ long, $8 \mathrm{~m}$ wide, and $6 \mathrm{~m}$ deep, although some trenches are up to $10.5 \mathrm{~m}$ deep. The bottoms of the trenches are well above the water table.

No special packaging is required for burial beyond those required for transportation by the Department of Transportation (DOT). Packaging methods currently used are not intended to provide containment after burial as the soil is considered to provide the essential containment. The bulk of the waste material is packaged in 210.1 iter mild steel drums approved by DOT. Very low activity wastes may be received in wood or fiberboard boxes. Wastes are usually buried in the packages in which they are shipped except that material shipped in expensive; reusable casks may be repackaged prior to burial.

An attempt is made to place waste packages in trenches in an orderly manner. Waste packages are placed in a trench to within $0.6 \mathrm{~m}$ of the ground level. When the trenches are filled they are backfilled with $2 \mathrm{~m}$ of earthfill and mounded to $1 \mathrm{~m}$ above grade down the axis of the trench. There is no problem with infilexation of water and no further special provisions are made for water collection and containment or for compacting or sealing the trench cover.

Permanent markers are required within one' year of the closing of a trench. The concrete posts used for markers include the following information:

\footnotetext{
- Trench number

- Date opened

- Date closed

- Location and definition of trench boundary

- Total activity in curies; amount of source material
} 
in pounds; and total amount of special nuclear material in grams Radionuclides with the greatest hazard potential Volume of waste

Written records of waste disposals are required to include package type; volume, weight, quantities of radionuclides, chemical and physical form of the waste, and the radiation exposure from the package.

\subsection{Special Management Techniques (Mu176, USERDA76a)}

For burial of gas containers, the license usually specifies that the containers be buried in an upright position with minimum spacing (10 ft) between containers. These wastes are placed in a steel can, filled with a desiccant, and sealed with tar or a similar material. The container is sealed in concrete in a clay, steel, or concrete pipe and placed in a trench. Gaseous wastes under pressures of more than 1 atm are not accepted for burial.

Fissionable materials are isolated in special trenches and criticality control is accomplished by restrictions on quantities and spacing. The operator must be able to locate and identify any packages of special nuclear material authorized for burial.

\subsection{Usage (Mu176, USNRC77, USDOE78a, USERDA76a, Le77)}

During the period from beginning of operations in 1965 through the end of 1976, there had been $13,520 \mathrm{~m}^{3}$ of solid waste buried at the Richland facility containing approximately $4.7 \times 10^{5}$ curies of byproduct activity. $57,000 \mathrm{~g}$ of special nuclear materials, and $11,600 \mathrm{~kg}$ of source material.

Only about 38 of the available capacity has been used. 


\subsection{Monitoring (USNRC76, CG076)}

The operator monitors the concentration of radioactivity quarterly in the water of 3 onsite wells and semi-annually in offsite surface water. They operate a continuous air monitor onsite and assay for radioactivity quarterly in soil and vegetation samples collected onsite.

The State of Washington had not conducted an independent monitoring program prior to 1975, but in 1974 it inspected the site and did independent radiation sampling.

\subsection{Identification of Problem Areas}

\section{1 site}

None identified.

\subsection{Waste}

The opinion of the U.S. Geological Survey is that more information is needed for all sites with respect to the ion exchange capacity of the soil and water chemistry. (USNRC77)

\section{3 iperatinn}

The depth of burial could be increased appreciably without coming unnecessarily close to the water table. This could greatly increase the capacity of burial per unit land area. However, the near surface earth material on the Hanford reservation has a shallow angle of repose which might limit the cost effectiveness of deeper trenches. (Mu176)

Future containers and transport shields should be designed to minimize the time required for offloading and handling and standardized to permit a mechanized handling system. (Mu176)

Disposal site operators rely on the package labels or shipping documents prepared by the waste producer to maintain records of the waste 
rather than performing assays of packages on receipt. Many records contain only general information on the form, composition, or isotopic content of the waste. Better information is required to enable the operators to optimize waste management operations. (Mu176, USNRC76)

\subsection{Performance Evaluation}

Further information on rates of infiltration, direction, and rate of ground water movement, and the connection between shallow and deep aquifers is needed to predict the direction and rate of radionuclide migration. (USNRC7G, CG076) 
Savannah River Plant, Aiken, South Carolina

\subsection{Site Characteristics}

1.1 Location (NAS72, Ho76, USERDA76c, NAS76, Fe63)

The Savannah River Plant (SRP) is located in South Carolina on an area of about 800 square kilometers along the Savannah River. It is near Aiken, South Carolina, about 35 kilometers downstream (southeast) from Augusta, Georgia and about 160 air kilometers (150 xiver miles) from the mouth of the Savannah River at Savannah, Georgia. The solid waste storage site, approximately 48 hectares, is located near the center of the plant area between two chemical separation areas.

1.2 Climate (USERDA76C, NAS76, Mac79, Ad78)

The climate of the region is mild and humid. The average temperature during the winter is $9^{\circ} \mathrm{C}\left(48^{\circ} \mathrm{F}\right)$ and during the simmer, $27^{\circ} \mathrm{C}\left(80^{\circ} \mathrm{F}\right)$. The annual mean rainfall is $1200 \mathrm{~mm}$ ( 47 inches) and is balanced by evapotranspiration. Snow and freezing rain are infrequent.

Tornadoes occur with an average frequency of about once in seven years. There has been no tornado damaqe to any facillity during 24 yeare of operation of the Savannah River Plant.

Tropical cyclones (hurricanes and tropical storms) occur along the sulth Aflantic Coast. $S \bar{R} \bar{P}$ is 160 kilometers inland and the high winds tend to diminish as the storms move over land.

1.3 Geology (NAS72, Ho76, USERDA76c, NAS76)

The Savannah Rlver plant is located in the coastal Plain geologic province which is characterized by flat, largely unconsolidated sediment of cretaceous age or younger. The Piedmont Plateau, underlain by igneous and 
metomorphic rocks, begins at the Fall Line, about $32 \mathrm{~km}$ northwest of the plantsite.

The major rock units are metamorphic rocks of pre-Mesozoic age, sedimentary rocks of Triassic age, and the Tuscaloosa Formation of Cretaceous age. The metamorphic basement consists of schist, gneiss, and metaquartzite. The Tuscaloosa Formation is 150 to 185 meters (500 to 600 feet) thick and is composed of sand and clay. It contains several prolific water-bearing zones. Above the Tuscaloosa lie about 100 meters ( 350 feet) of compact clays, sand, and sandy clays.

Diabase dikes have been mapped in adjacent regions of the Piedmont and may be encountered in further exploration of the site.

Moderate damage from earthquakes might be encountered in the area. Three centuries of recorded history of earthquakes indicate that an earthquake above an intensity of. VII on the Modified Mercalli scale would not be expected. No severe earthquake in the southeastern U.S. had been recorded prior to the 1886 Charleston earthquake, which was felt 1300 to $1600 \mathrm{~km}$ away and affected an area of $5 \times 10^{6}$ square kilometers. However, the Charleston earthquake caused only minor superficial changes to the ground surface.

1.4 Hydrology (NAS72, Ho76, USERDA76C, NAS76, Mac79, Ad78, USERDA76b, Co79)

The waste burial ground area is situated between Upper Three Runs Creek and Four Mile Creek; no flowing stream crosses the area. Drainage from the burial grounds area is to Four Mile Creek at a distance of about a half mile; Four Mile Creek then flows westward for about $24 \mathrm{~km}(15 \mathrm{mi})$ to the Savannah river. The Savannah River forms the southwest boundary of the reservation for about $27 \mathrm{~km}$. Flow in the Savannah River in the vicinity of 
the reservation is controlled to a yearly average of $295 \pm 80 \mathrm{~m}^{3} / \mathrm{sec}$ $(10,400 \pm 2900 \mathrm{cfs})$ by Clark Hill Reservoir and Hartwell Reservoir which are upstream. Water entering the Savannah River from the reservation requires a minimum of 3 days to reach the Atlantic Ocean and the average flow time is about 5 to 6 days.

In the burial ground area the normal depth to the water table is 6 to $18 \mathrm{~m}$ (20 to 60 feet). Seasonal fluctuations are normally less than 1 meter 12 feet) but have been as much as 2 meters ( 6 feet). Only about $460 \mathrm{~mm}$ ( 15 inches) of the average annual rainfall of $1200 \mathrm{~mm}$ (47 inches) infiltrates to the water table. The infiltration rate is about $2 \mathrm{~m}$ ( 7 feet) per year. At the water table the migration is laterally at a rate of about $12 \mathrm{~m}(40$ feet) per year to surface streams; the travel time to Four Mile creek would be about 70 years.

The Tuscaloosa Formation, which underlies the reservation at a depth of 100 meters, is a proliflc reglonal freshwater aquifer which supplies water for various uses at the plant and for municipal water supply in the area. Clay layers inhibit downward movement of water into the Tuscaloosa Formation in the burial ground area. There is a hydrostatic head reversal in the intervening Congaree Formation that indicates flow is into the Congaree Formation from both above and below.

\subsection{Ecology (USERDA76c)}

The SRP is a natural preserve for biota typical of the southeastern Coastal plain. The facilities occupy only a small fraction of the reservation and the wildife is little affected.

Over $90 \%$ of the area of the SRP is covered by pine and hardwood forests with habitats ranging from infertile dry hilltops to continually flooded swamps. At the time of acquisition about two thirds of the land 
was forested and one third was in cropland (primarily corn and cotton) and pastures. Most of the abandoned fields have been planted in pine.

The dry sandy soils are typically covered with scrub oak and longleaf pine. The Coastal Terraces have sandy loams of higher fertility which support oak-hickory hardwoods. Bottomland hardwood forests are found on moister soils, along small streams or on old flood plains. In the Savannah River swamp, bald cypress and tupelo gum are the dominant trees.

Animal life is abundant. The deer population is estimated at 5,000 to 8,000. Domestic hogs, abandoned when the site was acquired, reverted to the semi-wild state; feral dogs and cats are also present on the plantsite. Small mannuals are abundant on the plantsite. Less common species include the marsh rabbit and otter; and rare animals include the spotted skunk, cane cutter rabbit, black bear, mink and weasel. Biologists have identified 213 species of birds on the plantsite, including the endangered species bald eagle, redcockaded woodpecker, and Kirtland's warbler.

The SRP site supports a diverse population of reptiles and amphibians of species common to the southeastern Coastal Plain, including alligators.

Five natural streams and artificial water impoundments provide numerous and diversified habitats for fish. Most species reported in Lower Three Runs are those commonly considered to inhabit flowing waters. In Par Pond, which receives thermal discharges, the bass population is excessively high and other populations are declining. Forty-two species have been identified in Lower Three Run, 36 in Upper Three Runs, 25 . in Four Mile Creek, 24 in Steel Creek, and 16 in Pen Branch.

\subsection{Licensing}

Savaninalı River Plant is operated by the E.I. DuPont de Nemours and 
Co., a prime contractor for the U.S. Department of Energy, and is not a licensed facility. The operations are regulated by the U.S. Energy Research and Development Administration Manual Chapters.

\subsection{Operation}

\section{1 Dates of Operation (Ho76, USERDA76c)}

The solid waste storage site at SRP was established in 1952-53 before any radioactivity was generated onsite. Solid radioactive waste has been stored at one location since 1953. When the original area of 31 hectares (76 acres) was filled in 1972 operations were shifted to a 48 hectare ( 119 acre) contiguous area.

3.2 Operations Techniques (Ho76, USERDA 76c, Mac79, Ad78, Fe63)

The solid waste burial trenches are normally $6 \mathrm{~m}$ (20 feet) deep and 6 m (20 feet) wide in soil containing sufficient clay that the excavation will stay open without support. The length of the trenches is variable.

The bottom of the trench is at leasl $3 \mathrm{~m}$ (10 feet) above the water table and in an area where there is no perched water table. The topography must be level and surface water runoff controlled.

Low-level waste generated onstte at SRP ls nut requixed to be packaged. Low-level waste is unloaded manually or emptied directly 1nto trenches in a random manner. When the radiation exposure rate is high the waste is handled remotely; a shielded crane is used to handle waste with the highest exposure rates. The concentration and quantities of radionuclides in waste containers are limited to conform to criticality safety and heat load criteria.

Compactible waste constitutes about $40 \%$ of the total volume of waste 
buried at SRP but it is not compacted as burial space is abundant.

As soon as the waste is buried it is covered with soil to reduce radiation, prevent contamination, and prevent fires. The minimum soil cover is $1.2 \mathrm{~m}$ ( 4 feet), but must be sufficient to reduce the surface radiation exposure to $6 \mathrm{mR} / \mathrm{hr}$ or less.

The land surface is relatively level so surface erosion is not a problem. Pensacola Bahia grass and surface drainage ditches to channel runoff of surface water are used for further erosion control.

SRP has imposed administrative limits on the quantity of beta-gamma radioactivity and of specific radionuclides that can be emplaced in any given year. Waste is sorted and buried in 3 waste categories according to the type of radiation emitted. These categories are alpha, low level beta-gamma, and high level beta-gamma wastes. Permanent records and maps are maintained to inventory, locate, and identify stored waste. An accurate computerized record is kept of the contents, radiation level, and burial location of each load of waste received. The exact location of burial is defined by the use of a 100 foot grid system divided into 20 squares which were established in 1960. Prior to 1960 trenches were defined with concrete markers.

Protective clothing and hard hats are required for personnel handling waste. Only essential vehicles are permitted to enter the area and these are surveyed before leaving. The original 76-acre site is enclosed with an 8-foot high woven wire security fence. The new site is partially enclosed with a similar fence; the remainder is enclosed with a barbed wire fence.

\subsection{Special Management Techniques (Ho76)}

Occasionally, special wastes are received for land burial. In 1966, several thousand 55-gallon drums of soil and vegetation were received from 
decontamination of the ground at Palomares, spain, resulting from the collision of a bomber carrying nuclear weapons crashed in Greenland. Decontamination produced 535 containers of ice and aircraft parts which were sent to SRP for disposal.

Other special wastes include oil from gas displacement pumps in the tritium facilities which is placed in drums containing absorbent material before burial, mercury from gas pumps in tritium facilities (since 1968 mercury has been recycled), and tritiated wastes from Mound Laboratories.

3.4 Usage (Ho76, USERDA76c, NAS76, Mac79, USERDA76b, ga79, USDOE78)

Records on the volume of waste generated at SRP prior to 1973 are not readily available, but estimates have been made of the volumes and radioactivity of wastes that have been buried. It is estimated that 2.6 to $2.8 \times 10^{5} \mathrm{~m}^{3}$ of waste containing $8.0 \times 10^{6} \mathrm{Ci}$ of total radioactivity have been buried. The radioactivity includes $3.6 \times 10^{6} \mathrm{Ci}$ of tritium, $8.1 \times 10^{5}$ $\mathrm{Ci}$ of mixed fission products, and $3.6 \times 10^{6} \mathrm{Ci}$ of activation products.

At the end of 1977 , about $2.9 \times 10^{5} \mathrm{~m}^{2}$ of grass surfärê àrea had heen required for burial, leaving about $40 \%$ of the authorized burial space for future use. Based on current rates this should satisfy the needs of SRP for more than 30 years. There also is a good probability that additional areas for land burial could be located on the reservation.

4.0 Monitoring (Ho76, USERDA76C, Mac79, USERDA76a, DuP78C, DuP78b, DuP75, As76)

The overall environmental monttoring proyram for the SRP is quite extensive. Before the startup of SRP, baseline measurements of conditions in the Savannah River were made by the Academy of Natural Sciences in 
Philadelphia and by the Universities of South Carolina and Georgia. There is also an extensive network of ground water monitoring wells in the solid waste burial area. Five wells were installed at the perimeter of the original 31 hectare burial site in 1956 and six more were added after it was established that ground water flow was to the southwest. There are 11 dry borehole wells drilled to a depth of 15 meters (50 ft) through the actual waste emplacements; these are not open to soil water and are used to determine that the waste material remains where it is emplaced. In 1969, 24 trench wells were installed to sample any perched water that collects by percolation of rain through the backfilled trenches. Sixty-six wells are located on a grid with 200 foot centers; these wells penetrate 3 meters ( 10 ft) into the mean water table. In 1975, 35 additional wells were installed at the perimeter of the burial grounds, outside the fence; 16 of these wells replaced rine original perimeter wells. The perimeter wells penetrate 6 meters $(20 \mathrm{ft})$ into the water table.

The grid wells and perimeter wells are sampled quarterly and the boreholes are monitored annually. The inventory of tritium in ground water beneath the old 31 hectare sector of the storage site is $50,000 \mathrm{Ci}$; about $1,000 \mathrm{Ci}$ have migrated in the ground water into a 7 hectare area beyond the fence to the southwest. The area beneath the old 31 hectare sector of the storage site is also estimated to have an inventory of about $5 \mathrm{mCi}$ of alpha-emitters and about $30 \mathrm{mCi}$ of beta emitters.

There is no routine monitoring of air or soil specifically for burial ground operations, but samples of vegetation are collected annually. 


\subsection{Identification of Problem Areas}

\subsection{Site}

Mathematical models are being developed for prediction of the rate that soil erosion can remove the protective overburden from the wastes and expose them to man's activities. Rates of sheet erosion are estimated using a Soil Loss Equation, but erosion rates for gullies cannot be accurately predicted. (DuP78a)

\subsection{Waste}

A develupment program has been initiated at SRP to provide criteria and technology to allow isolation of solid wastes from man's environment with minimum reliance on human surveillance and intervention. (DuP74)

About 858 of the total buried radioactive waste contains tritium and its onsite migration has been documented, though the inventory in the ground water is only about one quarter of the amount predicted on the basis of the quantity buried and its known mobility. (Ho76, NAS76, USERDA76a, DuP 74)

Although tritium is the only radionuclide observed to have migrated through the ground from waste burial at SRP and its movement has been restricted to onsite, the combination of a humid environment and the observation that "perched" water in contact wi.th waste in the burial trenches always contains beta-gamma radioactivity suggests the potential for migration of radionuclides through the ground. Infiltration of surfare water through the trench cover to form a "perched" water table may be a potential future problem. (Ho76, USERDA76c, NAS76, USERDA76a)

SRP experience has shown that vegetation, especially deep-rooted plants, growing directly on the waste burial area can absorb significant amounts of radioactive materials. Herbicides are used to control 
vegetation and continuing studies are evaluating shallow rooted grasses and several nonvegetative soil covers as means for limiting vegetative uptake. ( Ho 76, DuP78c)

\subsection{Operation}

Fires have occurred in the trenches at SRP. Since 1973 combustible waste has been separated from noncombustible waste. (USERDA76c)

The operating life of the burial ground could be extended by waste compaction, use of standard packages, more volume effective placement of waste in the trenches, or. increasing trench width. Forty percent of the total volume of solid waste at SRP is compactible. (Ga79)

\subsection{Performance Evaluation}

An extensive network of monitoring wells at SRP has yielded considerable information on the lateral migration of radionuclides. Information on three-dimensional movement, particularly in the vertical direction, is less well known. This is of some importance at SRP as the Tuscaloosa Formation underlying the reservation in an important regional aquifer. (NAS76)

Some gaps exist in hydrogeological parameters affecting radionuclide migration, such as porosity and distribution coefficents under field conditions for specific radionuclides. Also needed is better information on the rate and extent of leachability of critical radionuclides from the waste. (NAS76, USERDA76b)

Tritium is an important radionuclide in wastes buried at SRP. It is mobile in ground water and also has a high vapor potential. Long-term studies are underway at SRP to determine the rate of its release to air and ground water. (Dup74) 
Sheffield, Illinois

\subsection{Site Characteristics}

\subsection{Location (Mul76, UNSRC77)}

The Sheffield Nuclear Center, operated by the Nuclear Engineering Co., Inc., is located about $8 \mathrm{~km}$ ( 5 miles) southwest of Sheffield, Illinois, on state-owned land. Sheffield is about $225 \mathrm{~km}(140$ miles $)$ west-southwest of Chicago and $70 \mathrm{~km}$ ( 45 miles) east-southeast of Moline.

\subsection{Climate (USERDA $/ 6 a$, Ad7y, Mä79)}

The climate is humid with a mean annual precipitation of about $900 \mathrm{~mm}$ ( 35 inches) which exceeds evapotranspiration by about 108.

\subsection{Geology (USERDA76a, Mac79)}

The bedrock is flat-lying shale, claystone, sandstone, and coal overlain with 20 to 30 meters of glacial drift consisting of sand, silt, and gravel. The site is in a class 1 seismic hazard zone.

\subsection{HydruluyY (USERDA7Ga, Ad70, Mac79)}

The regional aquifer lies at a depth of about 100 meters but there is a saturated zone in the glacial drift at a depth of 5 to 20 meters. The interstitial permeability of the glacial drift is variable, about 0.04 to $40 \mathrm{~cm} /$ day.

A small perennial river forms a part of the slle luurdary to the south. The area is part of the Spoon River drainage basin; the Spoon River flows into the Illinois and then Into the Mississippi River. The annual mean flow of the Mississippi Rlver at St. Louis, Missouri, is $4935 \mathrm{~m}^{3} /$ sec. In addition, there is a small lake to the north. 


\subsection{Ecology}

Approximately 208 of the Sheffield site is forested and is confined generally to areas surrounding the drainageways and intermittent streams. The vegetational area is described by Braun (1950) as the Prairie Peninsula Section of the Oak-Hickory Forest Region. The southern part of the site contains agricultural fields, idle fields, and remnants of secondary forests. Shrubby species on nearby fields and on the site include sumac, blackberry, and snowberry. The primary grasses are little bluestem and sidenat.s grama in fields that had not been recently plowed. In disturbed fields Kentucky blue grass and other species are dominant.

The principal species present or planted since disposal activities began are orchard grass, brome, and sweet clover. To discourage the establishment of woody species the area is mowed regularly.

Terrestrial animals whose ranges include the site are salamanders, frogs, snakes, turtles, toads, mice, squirrels, rabbits, skunks, raccoons, opossums, foxes and deer. There is little habitat available for animals that feed from or live in the water. Nearby farm ponds and strip mine lakes provide habitats for migrating water fowl and shorebirds.

The only natural aquatic habitat on site is a small stream which has some water flow most of the year. The closest lotic habitats likely to be affected by disposal are Lawson and King creeks located nearby.

Six threatened fish species possibly present in the Rock River system are listed by the State of Illinois. Two species prefer large rivers and would not be expected to migrate into the tributaries and the remaining four species are small fish which may occur in the watershed (Ar79).

Two threatened and 20 bird species with population declines have geographical ranges which include the site. The Indiana bat, an endangered 
mammal species, also occurs in this area. None of the above species has been recorded in the immediate vicinity of the disposal site.

\subsection{Licensing}

2.1 Date and Authority of License (Mul76, USNRC77, Ma76, USNRC76, USERDA76a, Mac79)
California Nuclear was originally licensed in 1966 by the state of
Illinois to "purchase, lease, accept or acquire suitable site for the
concentration and storage of radioactive waste" and the authority of the
Radioactive Waste Act, 1963, of Illinois. The site was bought by the
Director of Public Health. Since Illinois is not an agreement state, the operation of the facility was originally licensed by the U.S. Atomic Energy Authority in 1967 and is currently licensed by the U.S Nuclear Regulatory Commission (NRC). The State of Illinois licenses and controls activities at the site pertaining to radionuclides which are not subject to NRC control. California Nuclear sold its interests to Nuclear Enqineering Co.., Inc., in 1968 .

\subsection{License Conditions (Mu176, Ma76, USNRC76, USERDA76a, ICAE77)}

The Il page license from the State of Illinois permlts the operator to "purchase, lease, accept or acquire suitable site for the concentration and storage of radioactive wastes." The NRC licenses the operation of the site, but the State of Illinois also licenses and controls artivities at the site related to radionuclides not subject to NRC control.

The license from the state of Illinois specifies 30 conditions, including a concentration limit of $1 \mathrm{Ci} / \mathrm{ft}^{3} /$ package.

The solid wastes must be packaged, but spent filter cartridges in a disposable container are acceptable without solidification. Resins may be 
solidified with chemicals or cement.

Liquids must be solidified before burial, but bulk liquid shipments are accepted at the sheffield site and they have the authority and capability for their solidification. Liquid scintillation vials and gaseous waste are not accepted for burial. Radioactive wastes associated with toxic materials may not be buried if the chemical toxicity exceeds the radiological hazard.

The limits for possession of unburied material are 5,000 $\mathrm{Ci}$ of non-TRU byproduct material, 40,000 pounds of source material, $500 \mathrm{~g} 235 \mathrm{U}, 300 \mathrm{~g}$, ${ }^{238} \mathrm{U}$, and $300 \mathrm{~g} \mathrm{Pu}$. Transuranic material above $10 \mathrm{nCi} / \mathrm{g}$ is not accepted for burial.

A daily log of waste received is required to be maintained by the site operator showing quantity, type, and origin with container dose rates and transport class specified. Monthly summary reports are required to be made to the Department of Public Health on waste burials made during the reporting period.

Burial trench specifications are indicated. A separate, permanent concrete or metal marker indicating basic information on buried material is required to be placed at each end of filled trenches.

Determination of radioactivity levels in surface and ground water is required, and soil and vegetation sampling, on a quarterly or monthly basis, is specified. Quarterly environmental reports must be made to the Department of Public Health.

Other license terms of an administrative nature include:

a. Designation of operators and radiation safety or health physics staff.

b. Location of disposal operations. 


$$
\begin{aligned}
& \text { c. Burial charges. } \\
& \text { d. Leasing of land. } \\
& \text { e. License fees. } \\
& \text { f. Insurance. }
\end{aligned}
$$

\subsection{Operation}

3.1 Dates of Operation (USNRC77, Ma76, USNRC76, Mac79, ICAE77, B179) The operator was licensed by the State of Illinois in 1966 to acquilre the site for waste disposal. Operation of the facility by California Nuclear was licensed and commenced in 1967. Nuclear Engineering Co., Inc., purchased the interests of California Nuclear in 1968 and is the current operator.

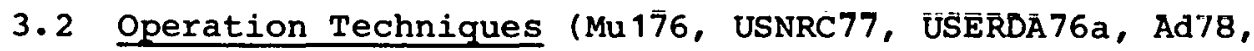

$$
\text { Mac79, ICAE77) }
$$

Trenches are constructed with conventional earth moving equipment. Typical trenches are $150 \mathrm{~m}$ long, 15-18 $\mathrm{m}$ wide, and 6-8 $\mathrm{m}$ deep. There is a minimum of $3 \mathrm{~m}$ at the surface between trenches.

No special packaging is required for burial beyond those required for transportation by the Department of Transportation (DOT). Packaging methods currently used are not intended to provide containment after burial as the waste material received is packaged in 210 l1ter mild steel drums approved by DOT. Very low activity wastes may be received in wood or fiberboard boxes. Wastes are usually buried in the packages in which they are shipped except that material shipped in expensive, reusable casks may be repackaged prior to burial. No attempt is made to place waste packages in trenches in an orderly manner. Waste packages are placed in a trench to within $0.6 \mathrm{~m}$ of the original ground level. 
A minimum of $1 \mathrm{~m}$ of compacted clay is used to cover the trench daily and it is mounded above grade down the axis of the trench. When the trench is filled the cover is reseeded.

Since water is the major vehicle for potential migration of radionuclides, water management is practiced at Sheffield. The bottom of the trenches are. sloped to the centerline and to one end of the trench where a sump and standpipe are located. Water can be removed from a trench, if necessary. Disposal operations are suspended during rains and if water is present in an open trench it is removed before waste packages are emplaced. Wastes are covered daily with compacted clay which is mounded above grade to reduce infiltration of rainwater and reseeded to reduce soil erosion. A surface drainage ditch of $0.6 \mathrm{~m}$ deep filled with broken brick is installed to carry water away from completed trenches.

Permanent markers are required within one year of the closing of a trench. The concrete posts used for markers include the following information:

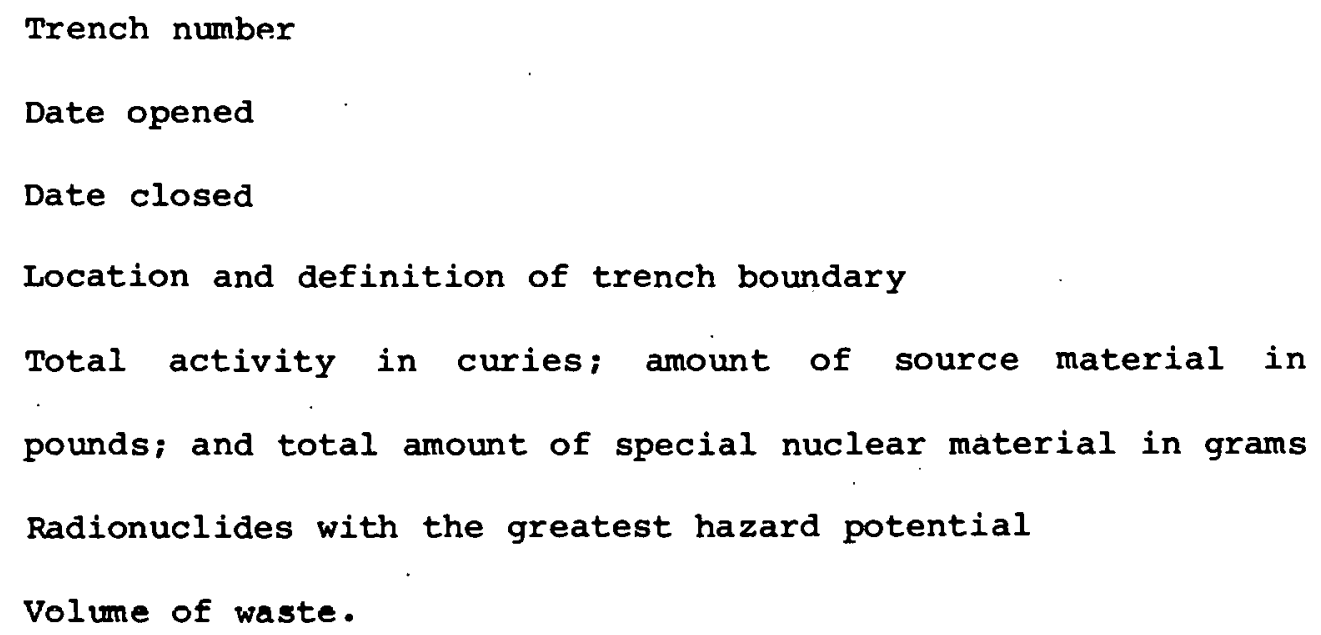
pounds; and total amount of special nuclear material in grams Radionuclides with the greatest hazard potential Volume of waste.

Written records of waste disposals are required to include package type, volume, weight, quantities of radionuclides, chemical and physical form of the waste, and the radiation exposure from the package. 
3.3 Operation (Mu 176, USNRC77, USDOE78a, USERDA76a, Ad78, Mac79, Le77, ICAE77, B176)

During the period from beginning of operation in 1967 through the end of 1976, there had been $69,000 \mathrm{~m}$ of solid waste buried at the Sheffield Nuclear Center containing approximately $4.7 \times 10^{4}$ curies of byproduct activity, $48,000 \mathrm{~g}$ of special nuclear materials, and $81,000 \mathrm{~kg}$ of source material. At the end of 1977, a total of $85,000 \mathrm{~m}^{3}$ of waste containing 58,000 Ci of byproduct activity had been buried.

l'he capacity of the site is approximately $2 \times 10^{5} \mathrm{~m}^{3}$ so the site is approaching its limits for further use unless it can be expanded. There are about 13 acres on the site that could be used to expand operations. This would provide about 7 to 8 years additional operation. NECo has also purchased 120 acres surrounding the present site, but the Bureau County Zoning Board of Appeals rejected the request by NECO for a variance from agricultural use in order to bury wastes in this acreage.

4.0 Monitoring (USNRC76, CG076, ÜSERDA776a, Ad78, ICAE77)

The operator monitors the concentration of radioactivity quarterly in the water of 8 onsite wells and in offsite surface water. An air monitor is operated continuously onsite and soil and vegetation samples are collected offsite and assayed quarterly for radoactivity.

The Department of Health samples 17 wells onsite, 4 private water wells offsite, 3 surface water locations, and other environmental sampling as deemed necessary and important.

No radionuclide migration has been observed, but NRC inspectors have noted that the placement of monitoring wells is not optimum for detection of migration. 


\subsection{Identification of Problem Areas}

\subsection{Site}

There is some concern for potential problems that could arise if the water table rose or a loss of control of surface water occurred. (USERDA76a)

Only the land being used for disposal is deeded to the state of Illinois and there is no buffer zone. (B179)

\subsection{Waste}

The facility frequently receives waste shipments with free-standing liquids in the containers, although it is only authorized to receive solidified wastes. (B179)

\subsection{Operation}

The capacity of the Sheffield site is limited, thus trenches should be arranged carefully to assure effective use of available land and the placement of packages in trenches to increase the efficiency of the trench capacity should be evaluated with respect to the increased personnel exposures that could result. (Mu176)

Future containers and transport shields should be designed, to minimize the time required for offloading and handling, and standardized to permit a mechanized handling system. (Mu176)

Disposal site operators rely on the package labels or shipping documents prepared by the waste producer to maintain records of the waste rather than performing assays of packages on receipt. Many records contain only general information on the form, composition, or isotopic content of the waste. Better information is required to enable the operators to optimize waste management operations. (Mu176, USERDA76a)

Criteria for decommissioning will need to be developed as the site 
reaches the limits of its capacity. (USNRC77)

\subsection{Performance Evaluation}

Further information is needed on the permeability of the soil and underlying formations, the depth to ground water and its fluctuations, and the direction of ground water movement to permit the prediction of the direction and rate of radionuclide migration. (USNRC76, CG076)

The location of ground water monitoring wells are not necessarily optimally placed for monitoring of radionuclide migration. (USNRC76, (G076) 


\subsection{Site Characteristics}

1.1 Location (Mu176, Ec78, Da76, USDOE79, Pru79)

The West valley burial site is part of the Western New York Nuclear Service Center at West Valley, New York, located about $50 \mathrm{~km}(30 \mathrm{miles})$ south of Buffalo, New York, on land owned by the State of New York and leased to Nuclear Fuel Services, Inc. The 1350 hectare (3345 acre) site is comprised of a low-level radioactive waste disposal area and a facility for the reprocessing of nuclear fuel. The designated burial area is approximately 10 hectares (25 acres), located 300 meters $(1000 \mathrm{ft})$ from the nearest tract perimeter.

\subsection{Climate (USERDA76a, Ad78, Mac79, DM76b)}

The site is in a humid region with a rainfall of about $1000 \mathrm{~mm}$ (39 in) and annual snowfall 2000-2540 mm ( 80 to $100 \mathrm{in}$ ). Rainfall normally exceeds evaporation on an annual basis. The average evapotranspiration rate is $480 \mathrm{~mm}(19 \mathrm{in})$ per year. The average temperature is $7^{\circ} \mathrm{C}\left(45^{\circ} \mathrm{F}\right)$.

\subsection{Geology (USERDA76a, Mac79, Ec78, Da76, Pru79)}

The West Valley site is located in the Appalachian Uplands physiographic province. The bedrock underlying the burial trench area is made up of interbedded siltstone and shales. The trenches are located in an area where the glacial till is 40 meters $(130 \mathrm{ft})$ thick or more. The till is composed primarily of pebbly clayey silt derived from lacustrine sediment which has been over-ridden and compacted by a later glacial advance. The permeability of the upper 10-12 meters $(30-40 \mathrm{ft})$ of till is low, being interrupted by only a few discontinuous layers of silt, sandy 
silt or gravelly silt, one to three feet thick, and by thin lenses of sand less than one inch thick. The surface $3-4.5$ meters $(10-15 \mathrm{ft})$ of till is slightly permeable silty clay interbedded with sand and gravel containing some fine fractures. Beneath the till is a sequence of fine sand 10 to 15 meters ( 30 to $50 \mathrm{ft}$ ) thick and below that undisturbed lacustrine varved clays.

The region is classed as a seismic Hazard zone 2 .

1.4 Hydrology (USERDA76a, Ad78, Mac79, Ec78, Ke179, Pru79)

Runott trom the buriài sité flows alrectly'info braman brook (Frank's Creek) to the east, which joins Buttermilk Creek about 0.5 miles downstream from the burial area. Stream flow in Erdman Brook is intermittent, varying between 0 and $3 \mathrm{~m}^{3} / \mathrm{sec}$. A mean discharge of $1.3 \mathrm{~m}^{3} / \mathrm{sec}$ for Buttermilk Creek has been reported with extremes of 0.06 to $110 \mathrm{~m}^{3} / \mathrm{sec}$ noted for a seven year study period. Buttermilk Creek empties into Cattaraugas Creek and finally into Lake Erie, $60 \mathrm{~km}$ (39 mi) away. Cattaraugas Creek has an average flow rate of $21 \mathrm{~m}^{3} / \mathrm{sec}$ at Gowanda, New York with recorded extremes of 0.16 to $980 \mathrm{~m}^{3} / \mathrm{sec}$.

The site is well-drained except for a marshy area to the south of the burial area, but perched water tables exist near trenches in the north burial site.

The interstitial permeability is low $(0.5 \mathrm{~cm} /$ day) and the principal flow paths away from the burial trenches are shale fractures and lenses in the drift. There is no regional aquifer; however, the depth to the water-table aquifer at the site was measured in the early 1960's and groundwater levels were generally $0-3$ meters $(0-10 \mathrm{ft})$ below ground. The depth to water is believed to be below the bottoms of the trenches in the south, but there are indications that the water table mayi intersect the 
trenches in the northern burial grounds. Water levels in trenches have been monitored regularly since 1966 by Nuclear Fuel Services.

\subsection{Ecology (Da76)}

The area consists of rolling uplands which are commonly farmed. The hillsides are wooded and the valley bottoms are narrow.

\subsection{Licensing}

2.1 Date and Authority of License (USNRC77, Ma76, USNRC76, USERDA76a， Le77, USDOQE79)

Nuclear Fuel Services (NFS) was originally licensed in November 1963 by the State of New York to "receive solid radioactive wastes packaged as designated, bury wastes by licensed procedures, maintain insurance from liability, special services from technical personnel available for damaged or noncompliant packages" under the authority of the New York State Sanitary Code, Exemption Sec. 16.8, part 16. The contract between NFS and the state requires the state to assume responsibility for the wastes at the end of 1980 .

\subsection{License Conditions (Mu176, USNRC77, Ma76, USERDA76a)}

The 5 page license from the State of New York authorizes the operation of a radioactive waste disposal site under 26 general terms and conditions and with general reference to State and Federal regulations.

Solid wastes must be packaged for burial. Filter aids are accepted for burial without absorption or solidification if the container has no free liquid and the surface exposure rates are less than $200 \mathrm{mR} / \mathrm{hr}$. If the surface exposure rates exceed $200 \mathrm{mR} / \mathrm{hr}$, the filter aids must be solidified in cement in a metal container or be packaged in a manner approved in writing by the site. Filter cartridges must be solidified in cement in 
metal containers or be packaged in an approved manner if their surface exposure rates exceed $200 \mathrm{mR} / \mathrm{hr}$.

Liquids may be absorbed if the surface exposure rate is less than $200 \mathrm{mR} / \mathrm{hr}$; if the exposure rate is higher they must be solidified.

Gaseous wastes are not accepted for burial, neither are explosive or pyrophoric materials or toxic wastes. No free water is allowed in packages and shipments must be in self-supporting, disposable containers.

West Valley has no limit on the curie quantity of non-transuranic by-product material that may be possessed unburied. The possession limits for special nuclear materials are $350 \mathrm{~g}{ }^{235} \mathrm{U}, 200 \mathrm{~g}{ }^{233} \mathrm{U}$, and $200 \mathrm{~g}$ Pu. The site has a self imposed limit of $1 \mathrm{~g}$ of ${ }^{239} \mathrm{Pu}$ per thousand cubic feet of waste or $0.1 \mathrm{~g}$ per package. Since October 1973 the Pu content of waste received for burial has been restricted to less than $10 \mathrm{nCi} / \mathrm{g}$.

A daily log of waste received is required to be maintained by the site operator showing quantity, type, and origin with container dose rates and transport. class specified. Periodic sumary reports are required on waste receipts, including volühe, activities, grams of speclal nuclear inaterial, pounds of source material, curies of byproduct material, and form of waste handled during the reporting period.

Burial trench specifications are indicated. A separate, permanent concrete or metal marker indicating baslc Information on buried materiā $\mathbf{i} \ddot{s}$ required to be placed at each end of filled trenches.

Determination of radioactivity levels in surface and ground water is required, and soil and vegetation sampling, on a quarterly or monthly basis, is specified.

Other license terms of an administrative nature include: a. Designation of operators and radiation safety or 
health physics staff.

b. Location of disposal operations.

c. Burial charges.

d. Leasing of land.

e. License fees.

f. Insurance.

The burial grounds are currently closed due to water management problems.

\subsection{Operation}

3. 1 Dates of Operation (USNRC77, Da76)

The West Valley burial trenches were operated from 1962 until the spring of 1975 when the site was closed due to water management considerations .

3.2 Operation Techniques (Mul76, USERDA76a, Ad78, Mac79, Ec78, Da76, Ke179, DM76b)

The trenches are excavated in glacial till and are from 180 to $210 \mathrm{~m}$ (590-688 ft) long, about $10 \mathrm{~m}(33 \mathrm{ft})$ wide, and 6 to $8 \mathrm{~m}(20-26 \mathrm{ft})$ deep. Each trench was dug in 30 to $60 \mathrm{~m}$ length sections as they were needed. Less than $15 \mathrm{~m}(40 \mathrm{ft})$ of open trench floor was maintained in front of the leading edge of the waste pile in order to minimize the inflow of rain and runoff into the trench. Trenches are separated by at least $3 \mathrm{~m}(10 \mathrm{ft})$ at the surface:

Self-supporting waste containers consisting of 55-gallon drums and rectangular containers made of cardboard, wood, and concrete were laid into the trench by hand. Containers with high levels of external radiation or too heavy to be laid by hand were placed in the trench by crane. Prior to 
1968 a minimum of $1.2 \dot{\mathrm{m}}(4 \mathrm{ft}$ ) of cover material was required above the emplaced waste in a completed trench. The minimum cover was increased to $2.4 \mathrm{~m}$ (8 $\mathrm{ft}$ ) in May 1968 and was applicable to trenches utilized after that date. Mounding of trench covers was not to exceed edge elevation by more than $0.6 \mathrm{~m}(2 \mathrm{ft})$. The trenches were filled to grade level, beginning at one end, and covered daily with compacted earthfill. When filled, topsoil is subsequently added and then seeded.

The trenches are sloped $2^{\circ}$ and a sump with a riser pipe is placed at the end for collection of water. The trench cover is also mounded to facilitate surface drainage and reduce infiltration.

Written records of waste disposals are required to include package type, volume, weight, quantities of radionuclides, chemical and physical form of the waste, and the radiation exposure from the package.

\subsection{Usage (USDOE78, USERDA76a, Ad78, Mac79, Le77)}

When the burial facility was closed in 1975, there had been $6.7 \times 10^{4}$ $\mathrm{m}^{3}$ of commercial solid waste buried at the site containing $5.8 \times 10^{5} \mathrm{Ci}$ of byproduct activity, $5.6 \times 10^{4} \mathrm{~g}$ of special nuclear material and $4.5 \times 10^{5}$ $\mathrm{kg}$ of source material.

Since 1967, there have been a total of 26 shipments of pesticides comprising $12 \mathrm{Ci}$ of ${ }^{14} \mathrm{C}$ and one $\mathrm{Ci}$ of ${ }^{3} \mathrm{H}$ and ${ }^{14} \mathrm{C}$ mixture. The total pesticide waste volume was about $15 \mathrm{~m}^{3}$.

\subsection{Monitoring (USNRC76, CG076, USERDA76a, Ec78, Pru79)}

NFS monitors 2 onsite streams quarterly and offsite surface water weekly. In high-flow the concentrations of radionuclides tend to be low, whereas during low-flow the concentrations are higher. A continuous air monitor is operated offsite. Offsite vegetation is monitored annually and 
offsite soil, quarterly. There is weekly monitoring of milk and offsite animals and fish are sampled semiannually.

The State of New York conducts an extensive environmental radioactive monitoring program throughout the state, including the area surrounding West valley. Water levels in trenches have been monitored regularly by Nuclear Fuel Services since 1966.

\subsection{Identification of Problem Areas}

\subsection{Jite}

The excavation of trenches in formations with low permeability and high rainfall results in increased rates of infiltration of precipitation through the cover which is more permeable than the native formation. This has occurred at West valley and has led to leaching of the waste and migration of the contaminated leachate through a zone of increased permeability at the seam between the original soil surface and the mounded backfill (CG076, USERDA76a, Me77, Ke179, Mat79).

The site needs further characterization with respect to a number of important geohydrological factors, such as direction and rate of ground-water movement (particularly movement through fractures), the extent of fractures, the source of water in the connection between sand deposits, and the ion exchange characteristics of the soil (USNRC76, Me77).

Sand lenses and failure joints exist in the burial formation and offer pathways for radionuclide migration (USNRC76, Me77, Ke179).

The waste could be potentially exposed by general erosion or structural failure of the trenches by landslides (Me77). 


\subsection{Waste}

Rising water levels in trenches during disposal operations first became a problem in 1968 and radioactivity was released when water was pumped from the trenches to a burial site lagoon. In 1972 contaminated water was pumped from the burial site lagoon, treated in the low-level waste treatment plant, and released to surface waters. In March 1975 increased levels of tritium were measured in water samples collected at onsite monitoring stations. The source was found to be a seep at the interface between the original till and the caps of two trenches. The flow rate was estimated to be about 1 gallon per day. Seepage was diverted to a holding lagoon. Based on discussions between NFS and state representatives, NFS suspended operations. Liquids were pumped from the trenches to a holding lagoon and were subsequently processed through the low-level treatment plant and released (USNRC77, Ma77, CG076, USERDA76a, Ad78, Da76, Mat791. .

The State's monitoring of the West Valley disposal site over past years detected small amounts of radioactivity in onsite streams. The activity appeared to be associated with surface contamination due to spills during burial operation and to deposits from stack discharges at the nuclear fuel reprocessing plant next to the disposai site (USNRC76, CG076, USERDA76a, Ad78, Kee77, Da76).

Anaerobic bacterial action in wastes can generate gases providing a mechanism for transport of radionuclides through the cap (Da76, Me77, Hu79, Mat79).

Detergents and complexing agents used for decontamination have been buried with wastes and can affect the rate of migration of radionuclides through the ground (Me77). 


\subsection{Operation}

Buildup of water has occurred in trenches constructed prior to 1968 in the north burial area. The permit was revised in 1968, revising the construction to minimize the entrance of water into the completed trenches. These trenches, located in the south burial ground, have not had a water problem (Kel79). The maintenance of the structural integrity of trench caps will help control leaching. Compaction and improved waste emplacement would reduce compaction of the waste, which has resulted in collapse of erench cuvers and increased infiltration of water (Da76, Me77).

Erosion control and water management are major environmental problems at the West valley site (Kel79).

\subsection{Performance Evaluation}

Insufficient hydrogeological. information is available to establish an adequate monitoring program. There are no performance standards against which to evaluate monitoring results (Me77). 
THIS PAGE

\section{WAS INTENTIONALLY \\ LEFT BLANK}


165

REFERENCES 
THIS PAGE

\section{WAS INTENTIONALLY \\ LEFT BLANK}




\section{REFERENCES}

Ad78 Adam, J.A., and V.L. Rogers. June 1978. "A Classification System for Radioactive Waste Disposal--What Waste Goes Where?" Ford, Bàcon, and Davis, Utah, for the U.S. Nuclear Regulatory Commission. NUREG/CR/0680.

Ah77 Ahlstrom, S.W., H.P. Foote, R.C. Arnett, C.R. Cole, and R.J. Serne. May 1977. "Multi-component Mass Transport Model: Theory and Numerical Implementation." (Discrete Parcel Random Walk Version) Battelle Northwest Laboratories, Richland, Washington.

Am76 Ames, L.L., D. Rai, R.J. Serne. 1976. "A Review of Actinide-Sediment Reactions with an Annotated Bibliography." Battelle Pacific Northwest Laboratories. BNWL-1983. 523 pages. (10 February 1976).

Ar79 Arnold, E. 1979. The Environmental Report," Ecology Section, Prepared by the Nuclear Engineering co., Inc., received by letter from E. Arnold, Administrative Assistant at NECO.

As76 Ashley, C., and C.C. Zeigler. 1976. "Environmental Monitoring at the Savannah River Plant." Health Physics Department, Savannah River Plant, E.I. DuPont de Nemours and Co., Aiken, South Carolina. DPSPU 77-302.

Ba76 Barraclough, J.T., J.B. Robertson, and V.J. Janzer. 1976. "Hydrology of the Solid Waste Burial Ground, As Related to the Potential Migration of Radionuclides, Idaho National Engineering Laboratory," USGS Open File Report 76-71.

Ba79 Barraclough, J.T., J.B. Robertson, and V.J. Janzer. 1979. "Geo-hydrologic Study of a Burial Site for Solid Low-Level Radioactive Wastes at the Idaho National Engineering Laboratory," in Management of Low Level Radioactive Waste, Volume 2. M.W. Carter, A.A. Moghissi, and B. Kahn, Editors. Pergamon Press, New York, pp. 795-824.

B179 Blackburn, J.A., and D.D. Ed. 1979. "Illinois Experiencewith Low-Levèl Waste Management," in Management of Low-Level Radioactive Waste, Volume 2. M.W. Carter, A.A. Moghissi, and B. Kahn, Editors. Pergamon Press, New York. pp. 837-841.

Bla79 Blake, E. Michael. December 1979. "Waste Management. Low-Level. Feeling the Pinch." Nuclear News, 22, No. 15, pp. 48-50.

Br77 Brown, D.J. and R.E. Isaacson. July 1977. "The Hanford Environment as Related to Radioactive Wa'ste Burial Grounds and Transuranium Waste Storage Facilities." ARH-ST-155.

Bu72 Burch, W.D. et al. September 1972. "Waste Management at ORNL: Present Practices--Immediate Needs--The Future." (The Final Report of the Committee on ORNL Waste Handling Practices.) ORNL-CF-72-9-1. 
CG076 Committee on Government Operations. 1976. "Hearings before a Sub-committee of the Committee on Government Operations--House of Representatives, Ninety-Fourth Congress, Second Session."

Ch65 Champlin, J.B.F., and G.G. Eichholz. February 1976. "Fixation and Remobilization of Trace Contaminants in simulated subsurface Aquifers." in Health Physics, 30(2), pp. 215-219.

Cl73 Clark, D.G. October 1973. "A History and Preliminary Inventory Report on the Kentucky Radioactive Waste Disposal Site," in Radiation Data and Reports, Volume 14, Number 10. U.S. Environmental Protection Agency, RDDRA4 14(10), 573-682.

Cli72 Cline, J.D. February 1972. "A Relatively Simple and Precise Technique for Assay of Plutonium Waste," National Reactor Testing station Idaho Falls, CD. ANCK-1055; 31 pp.

Co79 Cornman, W.R. 1979. "Improvement in Operating Incident Experience at the Savannah River Burial Ground," in Management of Low-Level Radioactive Waste, Volume 2. M.W. Carter, A.A. Moghissi, and B. Kahn, Editors. Pergamon Press, New York, pp. 787-794.

Da76 Davis, J.F., R.J. Dingman, R.H. Monheimer, and J.M. Matuszek, Jr. 1976. "Evaluation of Radionuclide Pathways at a Shallow, Low-Level Radioactive Waste Burial site in Western New York." Presented at the National Meeting of the Geological Society of America, 10 November 1976, by J.W. Pferd.

De77 Denham, (Rep.) M.B., M.D., et al. Octobex 1977. "Report of the Special Advisory Committee on Nuclear Waste Disposal." Legislative Research Commission, Frankfort, Kentucky.

DeB74 DeBuchananne, G.D. December 1974. "Geohydrologic Considerations in the Management of Radioactive Wastes," in Nuclear Technology 24, pp. 356-361.

Del56 Delaguna, W. 1956. "Some Geologic Factors that Influence Disposal of Radioactive Wastes into Pits," USGS Dak Ridge Nat1onal Laboratory. TID-7517.

DM76a Dames and Moore. July 1976. "Final Report. Development of Monitoring Programs for ERDA-Owned Radioactive Iow-Level Waste Burial Sites." Prepared for ERDA under contract E(49-1)-3759,

DM76b Dames and Moore. 1976. "Interim Status Report. Firt Stage. Development of Methods to Eliminate the Accumulation and Overflow of water in the Trenches at the Radioactive Waste Disposal site West Valley, New York". Prepared for the New York State Energy Research and Development Authority.

DM78 Dames and Moore. 1978. "Appilicability of a Generic Monitoring Program for Radioactive Waste Burial Grounds at Dak Ridge National Laboratory and Idaho National Engineering Laboratory." 
Du75 Duguid, J.O. July 1975. "Status Report on Radioactivity Movement from Burial Grounds in Melton and Bethel Valleys." ORNL-5017.

Du76a Duguid, J.O. October 1976. "Annual Progress Report of Burial Ground Studies at Oak Ridge National Laboratory: Period Ending September 30, 1975." ORNL-5141.

Du76b Duguid, J.O. and M. Reeves. 1976. "Material Transport Through Porouo Mcdia: A Finite Flemenl Galurkin Mudel," ORNL-1928.

Du76C Duguid, J.O. and M. Reeves. 1976. "Comparison of Mass Transport Using Average and Transient Rainfall Boundary Conditions," Oak Ridqe National Laboratory. Conference held in Princeton, New Jersey, July 1976. 11 pages.

trity Duguid, J.O. 1979. "Hydrologic Transport of Radionuclides from Low-Level Waste Burial Grounds," in Management of Low-Level Radioactive Waste, Volume 2. M.W. Carter, A.A. Moghissi, and B. Kahn, Editors. Pergamon Press, New York, pp. 1119-1137.

DuP74 E.I. DuPont de Nemours and Co. July-September 1974. "Savannah River Laboratory Quarterly Report." Waste management. DPST-74-125-3.

DuP75 E.I. DuPont de Nemours and Co. July-September 1975. "Savannah River Laboratory Quarterly Report." Waste Management. DPST-75-125-3.

DuP78a E.I. DuPont de Nemours and Co. January-March 1978. "Savannah River Labortory Quarterly Report." Waste Management DPST-78-125-1.

DuP78b E.I. DuPont de Nemours and Co. July-September 1978. "Savannah River Laboratory Quarterly Report." Waste Management. DPST-78-125-3.

DuP78C E.I. DuPont de Nemours and Co. April-June 1978. "Savannah River Laboratory Quarterly Report." Waste Management. DPST-78-125-2.

Ec78 Ecker, R.M. and Y. Onishi. December 1978. "Annual Progress Report October 1977 to September 1978. Sediment and Radionuclide Transport in Rivers. Field Sampling Program, Cattaraugus and Buttermilk Creeks, New York." NUREG/CR-U576.

EGH77 Environmental Group, H-8. 1977. "Development Activities on Shallow Land Disposal of Solid Radioactive Wastes, January-December 1976." Los Alamos Scientific Laboratory. LA-6856-PR.

E175 Eliason, J.F. 1975. "Characterization of 300 Area and WYE Burial Grounds." April-June 1975. BNWL-1936; pp. 59-62.

Fe63 Fenimore, J.W. May 1963; 1964. "Land Burial of Solid Radioactive Waste During a Ten-Year Period," in Health Physics 10, pp. 229-236.

Fo79 Ford, Bacon, and Davis, Utah Inc. 1979. "Evaluation of Alternative Methods for the Disposal of Low-Level Radioactive Wastes." Prepared for the U.S. Nuclear Regulatory Commission Low-Level Waste Branch. 
Fr.67 Frissel, M.J. and P. Poelstra. 1967. "Chromatographic Transport Through Soils I. Theoretical Evaluation," Plant and Soil, 26; p. 285.

Fre71 Freeze, R.A. April 1971. "Three-Dimensional Transient, Saturated-Unsaturated Flow in a Groundwater Basin." IBM Thomas J. Watson Research Center, Yorktown Heights, New York. Vol. 7, No. 2.

Fri76 Fried, S., A.M. Friedman, J.J.Hines, R.W. Atcher, L.A. Quarterman, and A. Volesky. December 1976. "Annual Report for Fiscal year 1976 on Project ANO115A: The Migration of Plutonium and Americium in the Lithosphere." ANL-76-127; ACS Symposium Series No. 35. Actinides in the Environment. Proceedings of a Symposium held in New York, New York, pp. 19-46, $107 \mathrm{pp}$.

Ga79 Garrett, P.M. January 26, 1979. "An Evaluation of Low-Level Radioactive Waste Burial Ground Capacities at the Major DOE Reservations." ORNL/NFW-79/17.

Gat75 Gat, U., J.D. Thomas and D.T. Clark. 1975. " "Radioactive Waste Inventory at Maxey Flats Nuclear Waste Burial Site," in Health Physics 30, March, pp. 281-298. Pergamon Press, 1976.

Ge77 Geiger, J.F., D.J. Brown, and R.E. Isaacson. August 1977. "Assessment of Hanford Burial Grounds and Interim TRU Storage." RHO-CD-78.

Gi77 Giardina, P.A., J.F. DeBonis, J. Eng, and G.L. Meyer. 1977. "Summary Report on the Low-Level Radioactive Waste Burial Site, West Valley, New York (1963-1975)." USEPA Region II, New York, New York.

G155 Glueckauf, E. 1955. "Theory of Chromatography, Part 9; The "Theoretical Plate" Concept in Column Separations," Trans. Far. Soc., $\underline{51}, 34$.

Ha73 Hakonson, T.E., J.W. Nyhan, L.J. Johnson and K.V. Bostick. May 1973. "Ecological Investigation of Radioactive Materials in Waste Discharge Areas at Los Alamos for the Period July 1, 1972 through March 31, 1973," LA-5282-MS.

Har79 Hardin, C.M. 1979. "Operational Experience of the Kentucky Radioactive Waste Disposal Site," in Management of Low Level Radioactive Waste, Volumw 2. M.W. Carter, A.A. Moghissi, and B. Kahn, Editors. Pergamon Press, New York, pp. 831-835.

Harn74 Harness, J.L. and R.W. Passmore. December 1976. "Onsite Environmental Surveillance Report for the INEL Radioactive Waste Management Complex Annual Report--1974." EG\&G Idaho, Inc. TREE-1014.

Hi52 Hiester, N.K. and T. Vermeulen. 1952. "Saturation Poerformance of Ion Exchange and Adsorption Columns," Chem. Engr. Prog. 48, 505. 
Ho76 Horton, J.H. and J.C. Corey. 1976. "Storing Solid Radioactive Wastes at the Savannah River Plant." E.I. DuPont de Nemours and Co., Savannah River Laboratory, Aiken, South Carolina. DP-1366.

Hu79 Husain, L., J.M. Matuszek, J. Hutchinson, and M. Wahlen. 1979. "Chemical and Radiochemical Character of Low-Level Radioactive Waste Burial Site," in Management of Low Level Radioactive Waste, Volume 2. M.W. Carter, A.A. Moghissi, and B. Kahn, Editors. Pergamon Press, New York, Pp. 883-900.

IAEA65 International Atomic Energy Agency. 1965. Radioactive Waste Disposal Into the Ground. Safety Series, No. 15, IAEA, Vienna.

ICAE77 Illinois Commission on Atomic Energy. 1977. "Report to the Honorable James R. Thompson, Governor of the State of Illinois, The President of the Senate and the Members of the Senate, the Speaker of the House and the Members of the House of Representatives of the Eightieth General Assembly." NP-22418.

In74 Inoue, $Y_{.}$, and $S$. Morisawa. January 1974, "On the Selection of a Ground Disposal site for Radioactive Wastes: An Approach to Its Safety Evaluation," Health Physics 26, pp. 53-63.

In75 Inoue, Y., S. Morisawa, and Y. Mahara. 1975. "Radionuclide Migration in Aerated Zones, (1) Migration Characteristics of Nuclides Contained in Percolating Water." Faculty of Engineering Kyoto University, Japan. ORNL-tr-4442, 15 pages. Nippon Genshiryku Gakkai Shi 17(7), pp. 376-384. (Translated by A. Bach, Techtran Corp.)

In76a. Inoue, Y., S. Morisawa, and Y. Mahara. 1976. "Radionuclide Migration in Aerated Zones, (II) Migration Characteristics of Sr-90 Leached out from Cememted Solid." Dept. of Sanitary Engineering, Kyoto University, Japan. ORNL-tr-4443; 10 pages. Hippon Gehshiryku Gakkai Shi 18(9), pp. 54-59. (Translated by A. Bach, Techtran Corp.)

In76b Inoue, $Y_{.}$, and S. Morisawa. 1976. "Distribution Coefficient ( $\mathrm{K}_{\mathrm{d}}$ ) of Radionuclides bbetween Sample Soil and Water." Dept. of Sanitary Engineering, Kyoto University, Japan, 24 pages; Nippon Genshiryku Gakkai Shi 18(8), pp. 524-534. (Translated by T.E. Oktami, ORNL)

Is78 Isaacson, R.E. and D.J. Brown. February 1978. "Environmental Assessment Related to hanford Radioactive waste Burial." Rockwell-Hanford Operations, Rishland, Washington.

Ja66 Jacobs, D.G. Winter 1966-67. "Behavior of Radioactive Gases Discharged into the Ground," Nuclear Safety $\underline{8}(2), 175$.

Jo78 Johnson, L.J. and H.M. Lewis. 1978. "Nuclear Waste Management Technology. Development Program, January-December 1977." Los Alamos Scientific Laboratory. LA-7501-PR.

KDHR74. Kentucky Department for Hhuman Resources. 1974. "Six Month Study of Radiation Concentrations and Transport Mechanisms at the maxey Flats Area of Fleming County, Kentucky." Open File Report KDHR, 
Frankfort, Kentucky.

Ke78 Keenan, T.K. October 1978. "Processing and Disposal of Radioactive Waste by the Waste Management Group at LASL." LOs Alamos Scientific Laboratory. LASL-78-83.

Kee77 Keeny, S.M. Jr. (Chairman), et. al. 1977. "Nuclear Power Issues and Choices." Report of the Nuclear Energy Policy Study Group. The MITRE Corporation, pp. 243-267. 418 pages.

Kel79 Kelleher, w.J. 1979. "Water Problems at the West Valley Burial Site," in Management of Low-Level Radioactive Waste, Volume 2. M.W. Carter, A.A. Moghissi, and B. Kahn, Editors. Pergamon Press, New York, pp. 843-851.

Ken79 Kendall, E.W. and J.D. McKinney. 1979. "Operational and Engineering Developments in the Management of Low-Level Radioactive Waste at the Idaho National Engineering Laboratory," in Management of Low-Level Radioactive Waste, Volume 2. M.W. Carter, A.A. Moghissi, and B. Kahn, Editors. Pergamon Press, New York, pp. 699-716.

Key76 Keys, w.S. and T.A. Taylor. 1976. "Technical Memorandum No. 37 Preliminary Interpretation of Geophysical Logs Made at Oak Ridge National Laboratory, Feb. 16-21, 1976." 10 pages. (Memo to D. Webster).

Ki76 Kitchings, T., L.K. Mann. 1976. "A. Description of the Terrestrial Ecology of the Oak Ridge Environmental Research Park," ORNL/TM-5073. Environmental Sciences Division.

Le77 Lerch, R.E. April 1977. "Division of Waste Management, Production and Reprocessing Programs Progress Report for January-December 1976." Hanford Engineering Development Laboratory.

Led77 Leddicotte, G.W., W.A. Rodger, R.L. Frendberg, H.W. Morton. May 23, 1977. "Suggested quantity and Concentration Limits to be Applied to Key Isotopes in Shallow Land Burial." CONF-770512. Proceedings of a Symposium held in Atlanta, Georgia, May 23-27, 1977, (30 pp.).

Ma76 Mann, B.J. and D.J. Nelson. June 1976. "Review of State Licenses for Disposal of Low-Level Radioactive Waste by Shallow Land Burial." Technical Note ORP/LV-76-3.

Mac79 Macbeth, P., G. Wehmann, B. Thamer and D. Card. July 1979. "Evaluation of Alternative Methods for the Disposal of Low-Level Radioactive Wastes." Ford, Bacon and Davis, Utah, Inc. for the U.S. Nuclear Regulatory Commission. NUREG/CR-0680.

Mat79 Matuszek, J.M., L. Husain, J.F. Davis, R.H. Fakundiny, R. Monheimer, J. Pferd, R. Dingman, and A.H. Lu. 1979. "Application of Radionuclide Pathway Studies to Short- and Long-Term management Insights for Shallow Low-Level Radioactive Waste Burial Facilities," in Management of Low-Level Radioactive Wastes, Volume 2. M.W. Carter, A.A. Moghissi, and B. Kahn, Editors. Pergamon press, New York, pp. 
$901-916$.

Mc78 McKenzie, T.R. August 31, 1978. "Storage and Disposal Program Plan," RHO-CD-429.

Me76 Meyer, G.L. 1976. "Preliminary Data on the Occurrence of Transuranium Nuclides in the Environment at the Radioactive Waste Burial Site Maxey Flats, Kentucky." USEPA-520/3-75/020.

Me77 Meyer, G.L. 1977. "Problems and Issues in the Ground Disposal of Low-Level Radioactive Wastes, 1977." Presented at ASME, USERDA, USEPA, USGS and USNRC Symposium on Management of Low-Level Radioactive Waste, Atlanta, Georgia, May 23-27, 1977.

Mea78 Means, J.L., D.A. Crerar, and J.O. Duguid. 1978. "Migration of Radioactive Wastes: Radionuclide Mobilization by Complexing Agents." Science 200, pp. 1477-1481 (30 June 1978).

Mo77 Montgomery, D.M., H.E. Kolde, and R.L. Blanchard. January 1977. "Radiological Measurements at the Maxey Flats Radioactive Waste Burial Site--1974-1975." EPA520/5-76/020.

Mo79 Montgomery, D.M. and R.L. Blanchard. 1979. "Radioactivity Measurements in the Environment of Maxey Flats Waste Burial Site," in Management of Low-Level Radioactive Wastes, Volume 2. M.W. Carter, A.A. Moghissi, and B. Kahn, Editors. Pergamon Press, New York..pp. 763-786.

Mu64 Mundorff, M.J., E.G. Crosthwaite, and C. Kilburn. 1964. "Ground Water for Irrigation in the Snake River Basin in Idaho." USGS Water-Supply Paper 1654.

Mul76 Mullarkey, T.B., T.L. Jentz, J.M. Connelly, M.P. Kane, Nus Corporation. October 1976. "A Survey and Evaluation of Handling and Disposing of Solid Low-Level Nuclear Fuel Cycle Wastes." Atomic Industrial Forum, Inc. National Environmental Studies Project.

Mus46 Muskat, M. 1946. The Flow of Homogeneous Fluids Through Porous Media, J.W. Edwards, Inc., Ann Arbor, Michigan.

NAS72 National Academy of Sciences and National Research Council. 1972. "An Evaluation of the Concept of Storing Radioactive Wastes in Bedrock Below the Savannah River Plant Site." Committee on Radioactive Waste Management, Washington, D.C.

NAS76 National Academy of Sciences. 1976. "The Shallow Land Burial of Low-Level Radioactively Contaminated Solid waste." Panel on Land Burial, Committee on Radioactive Waste Management, National Research Council, TID-27341.

Ne63 Nelson, R.W. et al. October 1963. "Steady Darcian Transport of Fluids in Heterogeneous Partially Saturated Porous Media," HW-72335.

Or56 Orcutt, R.G., I. Naor, G. Klein and W.J. Kaufman. 1956. "Hydraulic 
and Ion-Exchange Phenomena in the Underground Movement of Radiostrontium." Division of Civil Engineering and Irrigation, University of California, Berkeley, Califoria.

Os69 Osloond, J.H. and D.L. Newcomb. 1969. "Radioactive Waste Disposal Data for the National Reactor Testing Station, Idaho." U.S. Atomic Energy Commission, Idho Operations office. IDO-12040.

Ost63 Oster, C.A. May 1963. "Genero--A General Data Filling and Linear Functional Evaluation Computer Code for IBM 7090," HW-76692.

Pa74 Papadopoulos, S.S. and I.J. Winograd. 1974. "Storage of Low-Level Radioactive Wastes in the Ground: Hydrogeologic and Hydrochemical Factors, with an Appendix on the Maxey Flats, Kentucky, Radioactive Waste Storage site: Current Knowledge and Data Needs for a Uuantitative Hydrogeologic Evaluation." Open File Report 74-344.

Par62 Parsons, P.M. 1962. "Movement of Radioactive Waste Through Soil 3. Investigating the Migration of Fission Products from High-ionic Liquids Deposited in Soil." Atomic Energy of Canada, Limited.

Par63 Parsons, P.M. 1963. "Migration from a Disposal of Radioactive Liquid in Sands," Health Physics 9, pp. 333-342.

Ph77 Phillips, S.J. and J.R. Raymond. 1977. "Monitoring and Characterization of Radionuclide Transport in the Hydrogeologic System." Battelle Pacific Northwest Laboratories, Richland, Washington. BNWL-SA-5494, Part II. Conf-750967-16.

P177 Platt, A.M. November 1977. "Nuclear Wastè Management quarterly Progress Report April through June 1977." Battelle Pacific Northwest Laboratories. BNWL-2377-2.

PNL65 Pacific Northwest Laboratories. April 1965. "A Sequence for Predicting Waste Transport by Groundwater," BNWL-63.

Pr75 Prairie, R.I. 1975. "Radioactive Waste Inventory System for Maxey Flats." Final Report, Open File Report, USEPA, Washingtón, D.C.

Pru79 Prudic, D.E. and A.I. Randall. 1979. "Groundwater Hydrology and Subsurface Migration of Radioisotopes at a solld Radloactlve Wasle Disposal Site, West Valley, New York," in Management of Low-Level Radioactive Waste, Volume 2. M.W. Carter, A.A. Moghissi, and B. Kahn, Editorg, Fergamon Fres9, Ncw York, pp. 853-882.

Re70 Reiniger, P. June 1970. "Movement and Exchange of Sodium and Calcium in Calcareous and Gypseous soils--A Computer Approach to Soil Chromatography," Ph.D. Thesis submitted to the Hebrew University, Jerusalem.

Red70 Reddell, D.L. and D.K. Sunada. June 1970. "Numerical Simulation of Dispersion in Groundwater Aquifers." Colorado State University, Fort Collins, Colorado. No. 41. 
Rei70 Reisenauer, A.E., D.B. Cearlock, and C.A. Bryan. 1975. "Partially Saturated Transient Groundwater Flow Model Theory and Numerical Implementation." Battelle Pacific Northwest Laboratories, BNWL-1713. Appendix by G.S. Campbell, University of Montana, Missoula, Montana, and Washington State University, Pullman, Washington.

RHO77 Rockwell Hanford Operations. December 1977. "Quarterly Report Process Technology and Process Development, July 1977 through September 1977." 144 pages. RHO-LD-77-3 D.

Ri74 Richmond, C.R. and E.M. Sullivan. May 1974. "Annual Report of the Biomedical and Environmental Research Program of the LASL Health Division, January through December 1973." LA-5633-PR, p. 165.

Ric63 Richardson, R.M. 1963. "Significance of Coimate in Relation to the Disposal of Radioactive Waste at Shallow Depth Below Ground," in Proceedings of the International Colloguium on Retention and Migration of Radioactive Ions in Soils, Saclay, France, 16-18 October 1962. Presses Universitaires de France. pp. 205-211.

Ro73 Routson, R.C. March 1973. "A Review of Studies on Soil-Waste Relationships on the Hanford Reservation from 1944 to 1976." BNWL-1464. Battelle Pacific Northwest Laboratories.

Rob80 Robinson, R.A., Personal Communication on February 28, 1980.

Sc75 Schwartz, R.W. 1975. "On Radioactive Waste Management: An Anaysis of the Parameters Controlling Subsurface Contaminant Transfer," in Journal of Hydrology 27 (1975)51-71.

Sc77 Schwartz, R.W. 1977. "On Radioacive Waste Management: Model Analysis of a Proposed Site," in Journal of Hydrology 32, pp. 257-277.

Sh79 Shealy, H.G. 1979. "Operational and Engineering Experience in Waste Management," in Management of Low-Level Radioactive Wastes, Volume 2. M.W. Carter, A.A. Moghissi, and B. Kahn, Editors. Pergamon Press, New York, pp. 825-830.

Sha67 Shaikh, M.V., D.G. Jacobs, and F.L. Parker. January 1967. "A Study of the Movement of Radionuclides Through Saturated Porous Media," ORNL-TM-1681.

Sho79 Shord, A.L. September 1979. "Preliminary Criteria for Shallow Land Storage/Disposal of Low-Level Radioactive Solid Waste in an Arid Environment," RHO-CD-810.

SINB74 Southern Interstate Nuclear Board. February 1974. "Radioactive Waste Management, A Case Study." Administrator's Guide No. 5. Volume II. Atlanta, Georgia.

Su79 Sumner, W.B. and L.L. Thomas. 1979. "Description of Allied-General Nuclear Services On-site Solid waste Storage Concepts," in Management of Low-Level Radioactive Wastes, Volume 2. M.W. Carter, A.A. Moghissi, and B. Kahn, Editors. Pergamon Press, New York. pp. 
679-698.

Th50 Thompson, H.S. 1850. "On the Absorbent Power of Soils," J. Roy. Agr. Soc. Engl., 11, 68 .

Tho59 Thornthwaite, C.W., and J.R. Mather. 1959." "Investigation of the Climatic and Hydrologic Factors Affecting the Redistribution of Strontium-90 in the Soil," Publication in Climatology, Laboratory of Climatology, Centerton, N.J., 12, 51.

Thom44 Thomas, H.C. 1944. "Heterogeneous Ion Exchange in a Flowing System," J. Amer. Chem. Soc., 66, 1664.

Thomp79 Thompson, W.T. March 1979. "Shallow Land Burial--Why or Why Not?" Compilation of Papers Presented at the 1979 UCC-ND waste Management Seminar March 6-7, 1979. K/C-1347: M.E. Mitchell, (comp.) 404 gp.. p. $115=12 \dot{4}$.

USAEC73a U.S. Atopmic Energy Commission. 1973a. "NRTS Radioactive Waste Management Information for 1971." National Reactor Testing Station, IDO-10052.

USAEC73b U.S. Atomic Energy Commission. 1973b. "NRTS Radioactive Waste Management Information for 1972." National Reactor Testing Station, IDO-10053.

USAEC74 U.S. Atomic Energy Commission. 1974. "NRTS Radioactive Waste management Information for 1972." National Reactor Testing Station, IDO-10054.

USDOE78a U.S. Department of Energy. February 1978. "Report of Task Force for Review of Nuclear Waste Management." DOE/ER-0004/D.

USDOE78b U.S. Department of Energy, May 1978, "Draft Environmental Impact Statement. Ios Alamos Scientific Laboratory Site, Los Alamos, New Mexico." DOE/EIS-0018-D.

USDOE79 U.S. Department of Energy. April 1979. "Nuclear Waste Management Program Summary Document." DOE/ET-0094.

USEPA76 U.S. Environmemtal Protection Agency. May 1976. "Radiological Quality of the Environment." EPA Office of Radiation Programs.

USEPA77 U.S. Environmental Protection Agency. 1977 (in review). "Characterization of Reactor-Generated Low-Level Radioactive Waste." USEPA, Washington, D.C.

USERDA76a U.S. Energy Research and Development Administration. May 1976. "Alternatives for Managing Wastes from Reactors and Post-Fiscion Operations in the LWR Fuel Cycle." volume 4. ERDA-76-43.

USERDA76b. U.S. Energy Research and Development Administration. July 1976. "Development of Monitoring Programs for ERDA Owned Radioactive Low-Level Waste Burial Site." E(49-1)-3759. 
USERDA76c U.S. Energy Research and Development Administration. October 1976. "Waste Management Operations, Savannah River Plant, Aiken, South Carolina." ERDA-1537.

USERDA77 U.S. Energy Research and Development Administration. 1977. "Waste Management Operations, Idaho National Engineering Labortory, Idaho, Final Environmental Impact Statement," Washington, D.C.

USGS75 U.S. Geological Survey. August 1975. "Evaluation of Monitoring of Radioactive Solid-Waste Burial Sites at Los Alamos, New Mexico." Open File Report 75-046. Prepared for the U.S. Energy Research and Development Administration.

USGS76 U.S. Geological Survey. 1976. "A Review of Hydrologic and Geologic Conditions Related to the Radioactive Solid-Waste Burial Grounds at Oak Ridge National Laboratory, Tennessee." Open File Report 76-727.

USNRC76 U.S. Nuclear Regulatory Commission and U.S. Energy Research and Development Administration. January 12, 1976. "Improvements Needed in the Land Disposal of Radioactive Wastes-A Problem of Centuries." Report to the Congress by the Comptroller General of the United States. RED-76-54.

USNRC77 U.S. Nuclear Regulatory Commission. March 1977. "NRC Task Force Report on Review of the Federal/State Program for Regulation of Commercial Low-Level Radioactive Waste Burial Grounds." NUREG-0217.

Wa62 Walker, I.R. 1962. "Geologic and Hydrologic Evaluation of Proposed Site for Burial of Solid Radioactive Wastes Northwest of Morehead, Fleming County, Kentucky." Unpublished report on file at KDHR, Frankfort, Kentucky.

Way50 Way, J.F. 1850. "On the Power of Soils to Absorb manure," J. Roy. Agr. Soc. Engl., 11, 313:

Way52 Way, J.F. 1852. "On the Power of Sols to Absorb Manure," J. Roy. ngr. Soo. Engl., 13, 123.

We79 Webster, D.A. 1979. "Land Burial of Solid Radioactive Waste at Oak Ridge National Laboratory, Tennessee: A Case History," in Management of Low-Level Radioactive Wastes, Volume 2. M.W. Carter, A.A. Moghissi, and B. Kahn, Editors. Pergamon Press, New York. pp. 731-746.

Wh77 Wheeler, M.L., w.J. smith, A. F Gallegos. February 1977. "A Preliminary Evaluation of the Potential for Plutonium Release from Burial Grounds at Los Alamos Scientific Laboratory," LA6694-MS; 19 pages.

Ze77 Zehner, H.H. 1977 (in review). "Preliminary Hydrogeologic Study of the Radioactive Waste Burial Grounds, Maxey Flats, Kentucky." USEPA, Washington, D.C. 
THIS PAGE

\section{WAS INTENTIONALLY LEFT BLANK}


ORNL/SUB-80/13619/1

INTERNAL DISTRIBUTION

1. S. I. Auerbach

2. R. E. Blanco

3. R. O. Chester

4. J. H. Coobs

5. N. H. Cutshall

6. E. J. Frederick

7. D. E. Ferguson

8. R. B. Fitts

9. C. A. Little

10. T. F. Lomenick

11. A. L. Lotts

12. R. S. Lowrie
13. J. G. Moore

14. M. S. Moran

15. K. J. Notz

16. R. A. Robinson

17. T. Tamura

18. D. B. Trauger

19. I. E. Vath

20. N. D. Vaughan

21-25. Laboratory Records

26. Laboratory Records - RC

27. Patent Office

EXTERNAL DISTRIBUTION

28. L. Andrews, Chem. Nuclear, P.O. Box 1866, Bellevue, WA 98009

29. E. L. Albenesius, Savannah River Laboratory, Aiken, SC 29801

30. T. Bergstrom, University of Michigan, Ann Arbor, MI 48109

31. L. Bradley, 2726 Country Club Drive, O1ympia, WA 98502

32. R. L. Brodzinski, Battelle Northwest, 329 Bldg., 300 Area, Richland, WA 99352

33. R. Broseus, National Institute of Health, 9000 Rockville Pike, Bethesda, MD 20205

34. H. Brown, National Governors Association, 444 North Capital, Washington, DC 20555

35. P. Colombo, Brookhaven National Laboratory, B1dg. 830, Upton, NY. 11973

36. P. Costello, Office of the Governor, Statehouse, Boise, ID 83702

37. T. Deboer, Empire State Plaza, Albany, NY 12223

38. J. L. Deichman, Rockwell Hanford Operation, 2750 E. Bldg, 200 E. Area, P. O. Box 800, Richland, WA 99352

39. W. Dornseife, Pennsylvania Bureau of Radiation Protection, P.0. Box 2063, Harrisburg, PA 17120

40. L. Dressen, Division of Waste Products, B 107, Washington, DC 20545

41. J. P. Duguid, Battelle Project Management Division, 505 King Ave., Columbus, $\mathrm{OH} 43201$

42. L. Franks, Bureau of Consumer Health Protection, 505 King Street, Carson City, NV 89701

43. E. Fray, EG\&G Idaho, P.0. Box 1625, Idaho Falls, ID 83401 
44. G. Frieling, Wisconsin Electric Power Co., Milwaukee, WI 53201

45. R. H. Galbraith, 322 N. Lauderdale, Memphis, TN 38101

46. P. J. Gillis, Stone \& Webster, P.O. Box 2325, Boston, MA 02107

47. E. Held, Office of Nuclear Regulatory Research, Mail Stop 1130-SS, Washington, DC 20555

48. D. Jacobs, Evaluation Research Corporation, Oak Ridge, TN 37830

49. J. L. Johnson, Los Alamos Scientific Laboratory, P.0. Box 1663, Los Alamos, NM 87545

50-59. D. E. Large, Oak Ridge Operations, DOE, Oak Ridge, TN 37830

60. W. W. Larson, 81 Highland Circle, Wayland, MA 01788

61. D. Lavine, Deadhill Road, Durham, CT 06422

62. J. A. Lenhard, Oak Ridge Operations, DOE, Oak Ridge, TN 37830

63-82. G. B. Levin, EG\&G Idaho, P.0. Box 1625, Idaho Falls, ID 83401

83. T. McLaugh1in, EPA, 401 M Street, S.W., Washington, DC 20460

84. G. L. Meyer, EPA, 401 M Street, S.W., Washington, DC 20460

85. G. Oertel, Director, Division of Waste. Products, Office of Waste Management, DOE, Washington, DC 20545

86. J. Peel, Idaho Operations, DOE, 550 Second St., Idaho Falls, ID 83401

87. R. W. Peterson, ONWI Battelle Columbus Laboratory, 505 King Ave., Columbus, OH 43201

88. S. J. Phillips, Pacific Northwest Laboratory, Richland, WA 99352

89. R. Pope, Sandia Laboratories, P.0. Box 5800, Albuquerque, NM 87185

90. P. Psomas, Division of Waste Management, NRC, Washington, DC 20555

91. R. Raw1, Department of Transportation, Washington, DC 20460

92. J. R. Robertson, USCS, National Center MS 410, Reston, VA 22092

93. E. M. Romney, UCLA, 900 Veteral Ave., Los Angeles, C.A 90024

94. H. Shealey, Bureau of Radiological Health, 2600 Bull Street, Columbia, SC 29201

95. D. Smith, Division of Waste Management, NRC, Washingtnn, DC 20555

9h. J. G. Steger, Los Alamus 3lienllfle taboratory, P.U. Box 1663, LUs A1 amna; NM 87545

97. J. Watson, University of North Carolina, Chapel Hill, NC 27514

98. J. B. Whitsett, Idaho Operations, DOE, 550 Second St., Idaho Falls, ID 83401

99. T. Wolff, Environmental Improvement Division, P.0. Box 968, Santa Fc, NM 9750 ?

100. G. Yuan, Natural Resources Defense Council,.25 Kearney, San Francisco, CA 94108

101-127. Technical Information Center, DOE, Oak Ridge, TN 37830 